Henrique Caixeta Brigolini - Dr. Renata Veloso Santos Policarpo

Dr. Fernando Hadad Zaidan - Dr. Rafael Pinheiro Amantea

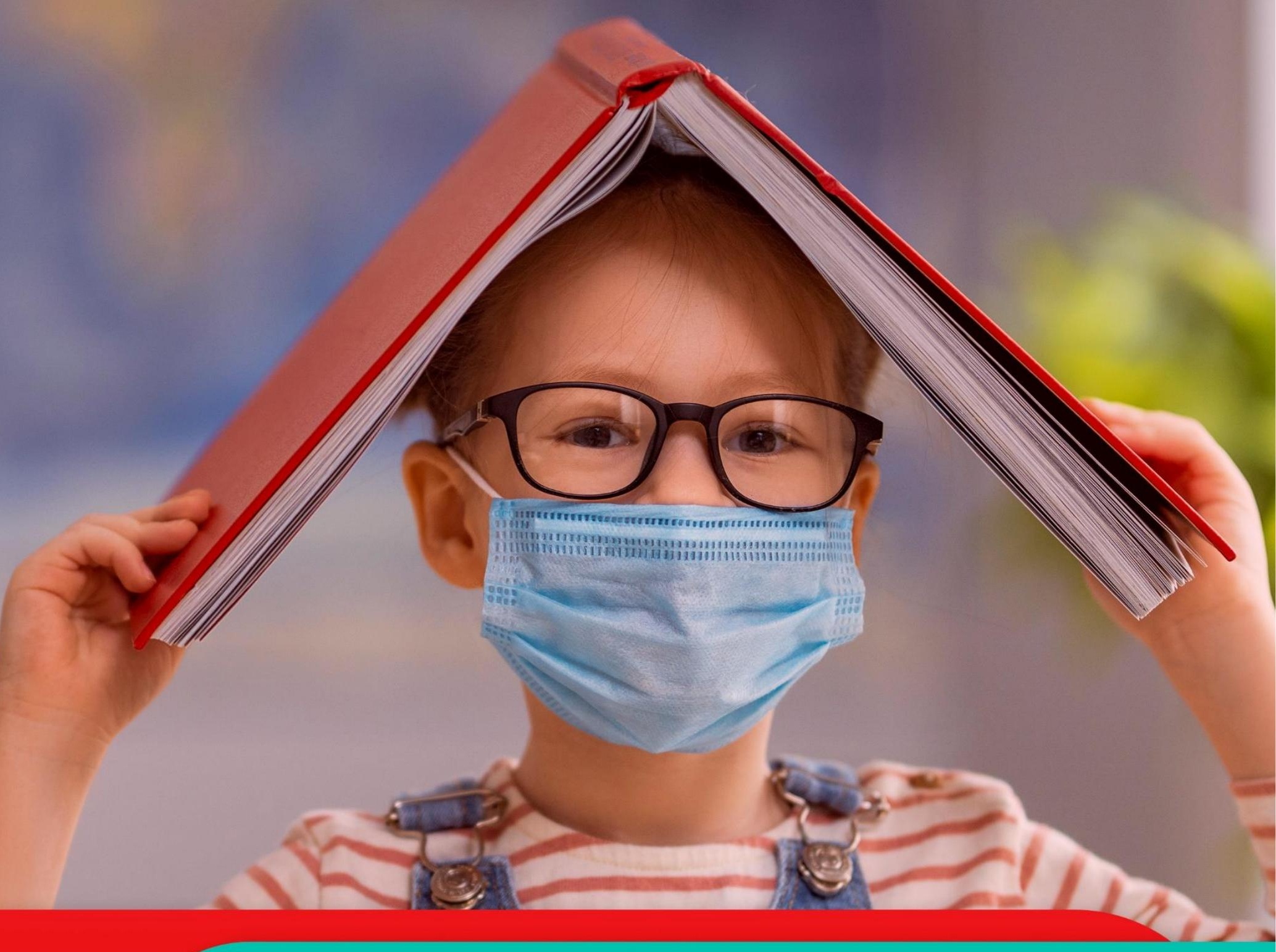

\title{
IMPLEMENTAÇÃO DA METODOLOGIA DE ANÁLISE E SOLUÇÃO DE PROBLEMAS (MASP) EM UMA ESCOLA PARTICULAR DURANTE A PANDEMIA DE COVID-19
}

\section{Vol. 01}

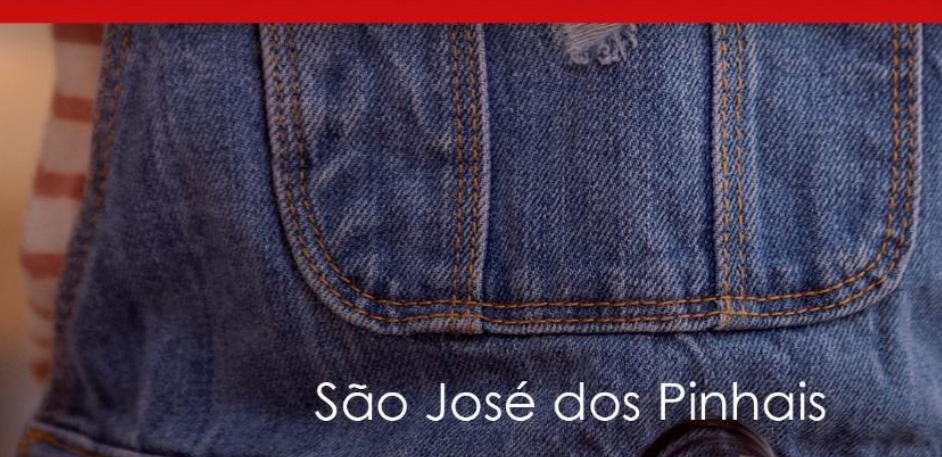

BRAZILIAN JOURNALS PUBHICAÇŌES DE PERIÓDICOS E EDITORA 2021 
Henrique Caixeta Brigolini - Dr. Renata Veloso Santos Policarpo

Dr. Fernando Hadad Zaidan - Dr. Rafael Pinheiro Amantea

Implementação da metodologia de análise e solução de problemas (MASP) em uma escola particular durante a pandemia de Covid-19

$1^{\circ}$ Edição

Brazilian Journals Editora

2021 


\author{
2021 by Brazilian Journals Editora \\ Copyright (C) Brazilian Journals Editora \\ Copyright do Texto (C2021 Os Autores \\ Copyright da Edição (2021 Brazilian Journals Editora \\ Editora Executiva: Barbara Luzia Sartor Bonfim \\ Diagramação: Sabrina Binotti \\ Edição de Arte: Sabrina Binotti \\ Revisão: Os Autores
}

O conteúdo do livro e seus dados em sua forma, correção e confiabilidade são de responsabilidade exclusiva dos autores. Permitido o download da obra e o compartilhamento desde que sejam atribuídos créditos aos autores, mas sem a possibilidade de alterá-la de nenhuma forma ou utilizá-la para fins comerciais.

Conselho Editorial:

Profä. Drª . Fátima Cibele Soares - Universidade Federal do Pampa, Brasil.

Prof. Dr. Gilson Silva Filho - Centro Universitário São Camilo, Brasil.

Prof. Msc. Júlio Nonato Silva Nascimento - Instituto Federal de Educação, Ciência e Tecnologia do Pará, Brasil.

Profa ${ }^{-}$. Msc. Adriana Karin Goelzer Leining - Universidade Federal do Paraná, Brasil. Prof. Msc. Ricardo Sérgio da Silva - Universidade Federal de Pernambuco, Brasil.

Prof. Esp. Haroldo Wilson da Silva - Universidade Estadual Paulista Júlio de Mesquita Filho, Brasil.

Prof. Dr. Orlando Silvestre Fragata - Universidade Fernando Pessoa, Portugal.

Prof. Dr. Orlando Ramos do Nascimento Júnior - Universidade Estadual de Alagoas, Brasil.

Profá. Drạ. Angela Maria Pires Caniato - Universidade Estadual de Maringá, Brasil. Profá. Drạ. Genira Carneiro de Araujo - Universidade do Estado da Bahia, Brasil.

Prof. Dr. José Arilson de Souza - Universidade Federal de Rondônia, Brasil.

Profa ${ }^{-}$. Msc. Maria Elena Nascimento de Lima - Universidade do Estado do Pará, Brasil.

Prof. Caio Henrique Ungarato Fiorese - Universidade Federal do Espírito Santo, Brasil.

Prof ${ }^{a}$. Drª . Silvana Saionara Gollo - Instituto Federal de Educação, Ciência e Tecnologia do Rio Grande do Sul, Brasil.

Profa . Dra . Mariza Ferreira da Silva - Universidade Federal do Paraná, Brasil.

Prof. Msc. Daniel Molina Botache - Universidad del Tolima, Colômbia.

Prof. Dr. Armando Carlos de Pina Filho- Universidade Federal do Rio de Janeiro, Brasil.

Prof. Dr. Hudson do Vale de Oliveira- Instituto Federal de Educação, Ciência e Tecnologia de Roraima, Brasil.

Profa ${ }^{a}$. Msc. Juliana Barbosa de Faria - Universidade Federal do Triângulo Mineiro, Brasil. 


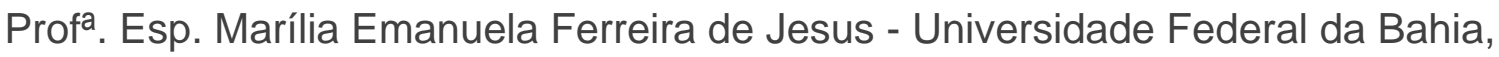
Brasil.

Prof. Msc. Jadson Justi - Universidade Federal do Amazonas, Brasil.

Prof ${ }^{a}$. Dr ${ }^{a}$. Alexandra Ferronato Beatrici - Instituto Federal de Educação, Ciência e Tecnologia do Rio Grande do Sul, Brasil.

Profa. Msc. Caroline Gomes Mâcedo - Universidade Federal do Pará, Brasil.

Prof. Dr. Dilson Henrique Ramos Evangelista - Universidade Federal do Sul e

Sudeste do Pará, Brasil.

Prof. Dr. Edmilson Cesar Bortoletto - Universidade Estadual de Maringá, Brasil.

Prof. Msc. Raphael Magalhães Hoed - Instituto Federal do Norte de Minas Gerais, Brasil.

Profa ${ }^{-}$Msc. Eulália Cristina Costa de Carvalho - Universidade Federal do Maranhão, Brasil.

Prof. Msc. Fabiano Roberto Santos de Lima - Centro Universitário Geraldo di Biase, Brasil.

Prof ${ }^{a}$. Dr ${ }^{\text {a }}$. Gabrielle de Souza Rocha - Universidade Federal Fluminense, Brasil.

Prof. Dr. Helder Antônio da Silva, Instituto Federal de Educação do Sudeste de Minas Gerais, Brasil.

Prof ${ }^{\mathrm{a}}$. Esp. Lida Graciela Valenzuela de Brull - Universidad Nacional de Pilar,

Paraguai.

Profa ${ }^{-}$. Drª - Jane Marlei Boeira - Universidade Estadual do Rio Grande do Sul, Brasil.

Prof ${ }^{a}$. Dra ${ }^{\text {. }}$. Carolina de Castro Nadaf Leal - Universidade Estácio de Sá, Brasil.

Prof. Dr. Carlos Alberto Mendes Morais - Universidade do Vale do Rio do Sino, Brasil.

Prof. Dr. Richard Silva Martins - Instituto Federal de Educação, Ciência e Tecnologia Sul Rio Grandense, Brasil.

Profa ${ }^{\text {. Dr }}$. Ana Lídia Tonani Tolfo - Centro Universitário de Rio Preto, Brasil.

Prof. Dr. André Luís Ribeiro Lacerda - Universidade Federal de Mato Grosso, Brasil.

Prof. Dr. Wagner Corsino Enedino - Universidade Federal de Mato Grosso, Brasil.

Profa. Msc. Scheila Daiana Severo Hollveg - Universidade Franciscana, Brasil.

Prof. Dr. José Alberto Yemal - Universidade Paulista, Brasil.

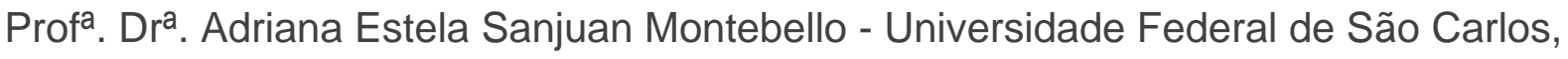
Brasil.

Profạ. Msc. Onofre Vargas Júnior - Instituto Federal de Educação, Ciência e

Tecnologia Goiano, Brasil.

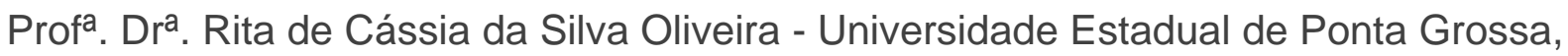
Brasil.

Profa ${ }^{-}$. Dr ${ }^{\text {a }}$. Leticia Dias Lima Jedlicka - Universidade Federal do Sul e Sudeste do Pará, Brasil.

Profa ${ }^{-}$. Dr ${ }^{\text {a }}$. Joseina Moutinho Tavares - Instituto Federal da Bahia, Brasil

Prof. Dr. Paulo Henrique de Miranda Montenegro - Universidade Federal da Paraíba, Brasil. 
Prof. Dr. Claudinei de Souza Guimarães - Universidade Federal do Rio de Janeiro, Brasil.

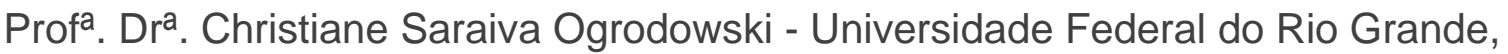
Brasil.

Prof ${ }^{a}$. Dra ${ }^{\text {. }}$. Celeide Pereira - Universidade Tecnológica Federal do Paraná, Brasil. Profa. Msc. Alexandra da Rocha Gomes - Centro Universitário Unifacvest, Brasil. Profạ. Drª. Djanavia Azevêdo da Luz - Universidade Federal do Maranhão, Brasil. Prof. Dr. Eduardo Dória Silva - Universidade Federal de Pernambuco, Brasil. Profa. Msc. Juliane de Almeida Lira - Faculdade de Itaituba, Brasil.

Prof. Dr. Luiz Antonio Souza de Araujo - Universidade Federal Fluminense, Brasil. Prof. Dr. Rafael de Almeida Schiavon - Universidade Estadual de Maringá, Brasil. Profa . Dra . Rejane Marie Barbosa Davim - Universidade Federal do Rio Grande do Norte, Brasil.

Prof. Msc. Salvador Viana Gomes Junior - Universidade Potiguar, Brasil.

Prof. Dr. Caio Marcio Barros de Oliveira - Universidade Federal do Maranhão, Brasil.

Prof. Dr. Cleiseano Emanuel da Silva Paniagua - Instituto Federal de Educação, Ciência e Tecnologia de Goiás, Brasil.

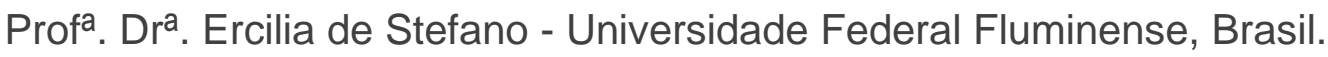




\section{Dados Internacionais de Catalogação na Publicação (CIP)}

B856i Brigolini, Henrique Caixeta

Implementação da metodologia de análise e solução de problemas (MASP) em uma escola particular durante a pandemia de Covid-19 / Henrique Caixeta Brigolini. São José dos Pinhais: Editora Brazilian Journals, 2021.

$87 \mathrm{p}$.

Formato: PDF

Requisitos de sistema: Adobe Acrobat Reader Modo de acesso: World Wide Web

Inclui: Bibliografia

ISBN: 978-65-86230-90-1

DOI: $10.35587 /$ brj.ed.0000959

1. Metodologia de análise e solução de problemas. 2. Gestão escolar.

3. Pandemia. I. Brigolini, Henrique Caixeta. II. Título.

Brazilian Journals Editora

São José dos Pinhais - Paraná - Brasil

www.brazilianjournals.com.br

editora@brazilianjournals.com.br 


\section{AUTORES}

Henrique Caixeta Brigolini - Mestre em Engenharia e Gestão de Processos e Sistemas no IETEC - Belo Horizonte (2021). Graduado do curso de Bacharelado em Engenharia de Produção no IFMG - Campus Congonhas (2015), onde teve a oportunidade de desenvolver três projetos de iniciação cientifica em diferentes áreas de conhecimento. Estudou Inglês no Spring Intenational Language Center em Arkansas, Estados Unidos onde estudou também a cultura americana assim como a maneira de escrever artigos científicos em inglês. Estudou também na University of Arkansas - USA (2013 e 2014) pelo programa Ciências sem Fronteiras como bolsista da CAPES. Gestor e Sócio desde 2015 da escola Instituto Educacional da Mônica, situada em Belo Horizonte.

Dr. Renata Veloso Santos Policarpo - Doutora em Administração pela Universidade Federal de Minas Gerais - UFMG. Mestre em Administração Universidade FUMEC. Especialista em Gestão Estratégica em Finanças pela UFSJ (2006) e MBA em Gestão de Negócios pela Fundação Getúlio Vargas FGV (2005) com módulo internacional pela Ohio University. Graduada em Administração pela UFSJ (2002) e em Ciências Contábeis pela Universidade Fumec (2019). Professora de graduação, pós-graduação e pesquisadora no Instituto Federal de Educação, Ciência e Tecnologia de Minas Gerais Campus Congonhas. Tem experiência na área de Administração e Engenharia de Produção, com ênfase em Administração Geral, atuando principalmente nos seguintes temas: Administração Financeira, Gestão Estratégica em Organizações, Comportamento Organizacional, Viabilidade Econômica de Investimentos, Custos Logísticos e Engenharia Econômica. Autora e co-autora de artigos em periódicos nacionais e internacionais, capítulos de livros e coletâneas. Membro do comitê editorial da Revista For Science do IFMG e coordenadora de grupo de pesquisa cadastrado no CNPQ.

Dr. Fernando Hadad Zaidan - Carreira de mais de 35 anos nas áreas de Tecnologia e Sistemas de Informação, com formação interdisciplinar: doutorado em Ciência da Informação pela Universidade Federal de Minas Gerais (UFMG), mestrado em Administração pela Fundação Mineira de Educação e Cultura (Fumec), bacharelado em Ciência da Computação pela Fumec, Gestão e Desenvolvimento Web-XML pela UniBH e Programação e Análise de Sistemas pela UFMG. Primeiras atividades no início dos anos 1980, como professor da linguagem de programação BASIC e empreendedor na Logik Software, desenvolvendo sistemas para microcomputadores. Fundador e gestor de startups na área de games, consultor nos projetos Sebraetec em parceria com a Fumsoft, experiência em projetos de P\&D na Cemig. As áreas de consultoria perpassam a gestão estratégica da TI, gestão do conhecimento, transformação digital, business intelligence, arquitetura corporativa, metodologias ativas de aprendizagem, métodos ágeis de projetos e gestão de processos de negócios. Palestrante em diversos congressos, simpósios, seminários e webinars. Professor e coordenador de cursos de pós-graduações Lato Sensu em diversas instituições de ensino. Professor e pesquisador de mestrado do Instituto de Educação Tecnológica (letec), priorizando as pesquisas sustentadas pelas metodologias design science e revisão sistemática de literatura. Publicações em congressos nacionais e internacionais, periódicos, livros e capítulos, com premiações de best papers. Membro avaliador do Talento Profissional, do programa 
de empreendedorismo, e das 100+ mais inovadoras no uso da TI. Criador do Knowledge Management Canvas (KMCanvas), o Canvas para a gestão do conhecimento (www.kmcanvas.com.br).

Dr. Rafael Pinheiro Amantea - Possui graduação em Sistemas de Informação pelo Centro Universitário UNA (2005), mestrado em Engenharia Agrícola pela Universidade Federal de Viçosa (2008) e doutorado em Engenharia Agrícola pela Universidade Federal de Viçosa (2012). Atualmente é professor Adjunto do IBMEC Instituto Brasileiro de Mercados e Capitais. Pesquisador e professor no Instituto de Educação Tecnológica - IETEC (Mestrado em Engenharia e Gestão de Processos e Sistemas). Tem experiência nas áreas de fenômenos de transporte, termodinâmica e técnicas numéricas de simulação e otimização de processos. 


\section{AGRADECIMENTOS}

Agradeço primeiramente a Deus por me acompanhar cada dia da minha vida.

A minha mãe, que me proporcionou todos os recursos necessários para eu chegar até aqui, fossem eles financeiros ou não. Ao meu pai, por estar presente. E a minha irmã, por me apoiar sempre, estando comigo nos momentos difíceis e momentos alegres da minha vida.

Agradeço ao meu orientador por me proporcionar crescimento a cada minuto ao seu lado. Aos professores do letec, pelo excelente trabalho desenvolvido.

Agradeço a toda minha família e amigos por todo o apoio. 
RESUMO: O objetivo deste estudo foi aplicar a metodologia de análise e solução de problemas em uma empresa de educação que atende crianças como suporte na solução de problemas durante a pandemia do novo coronavírus. Para isso, um estudo de caso foi realizado aplicando as etapas de identificação, observação, análise do problema, plano de ação, ação, verificação, padronização e conclusão, que perfazem um ciclo da metodologia. Esse ciclo foi aplicado sete vezes ao longo deste estudo de modo a mitigar os problemas que foram surgindo. Foi escolhida uma escola particular que atende crianças com idade inferior a 10 anos e superior a 2 anos situada na região metropolitana de Belo Horizonte. Em conclusão, o estudo auxiliou na melhora da relação entre a escola e família durante o período pandêmico, na implantação e no fornecimento das atividades de aperfeiçoamento pedagógico e das aulas on-line acessíveis aos alunos, na precificação das mensalidades, no sistema de avaliação, na organização dos planos de aulas de acordo com a exigência da Secretaria de Educação, no processo de matrícula e nas adequações para o possível retorno das aulas presenciais.

PALAVRAS-CHAVE: Metodologia de análise e solução de problemas; Gestão escolar; Escola privada; Ferramentas da qualidade; Pandemia. 
ABSTRACT: The study objective was to apply the Methodology for Analysis and Problem Solvingin an education company that attends children as support in solving problems during the pandemic of the new coronavirus. For this, a case study was carried out by the steps of identification, observation, problem analyzing, action plan, action, standardization and conclusion, which make up a cycle of the methodology. This cycle was applied seven times in this study course in order to mitigate the problems that have been arising.A private school was chosen to serve children under the age of 10 and over 2 years old, located in the metropolitan region of Belo Horizonte. In conclusion, the study helped to improve the relationship between school and family during the pandemic period, in the implementation and provision of pedagogical improvement activities and online classes accessible to students, in the pricing of tuition fees, in the evaluation system, in the organization of lesson plans according to the requirements of the Department of Education, in the enrollment process and in the adjustments for the possible return of face-to-face classes.

KEYWORDS: QC Story; School management; Private school; Quality tools; Pandemic. 


\section{LISTA DE FIGURAS}

Figura 1 - Metodologia de solução de problemas (QC-Story) ………....................10

Figura 2 - Etapas dos ciclos da MASP aplicada na instituição ................................16

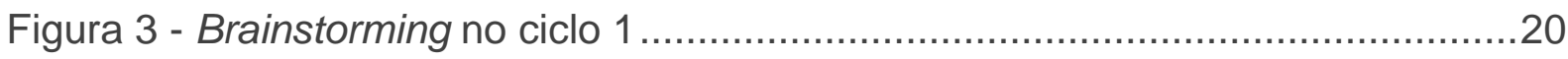

Figura 4 - Diagrama de Ishikawa sobre a falta de comunicação em grande escala com os pais .22

Figura 5 - Aplicação da técnica dos cinco porquês sobre manter o desenvolvimento com atividades aos alunos

Figura 6 - Aplicação da técnica dos cinco porquês sobre a entrega das atividades aos alunos seguindo os protocolos de saúde .24

Figura 7 - Fluxograma para adaptação da comunicação para o meio virtual...... 25

Figura 8 - Brainstorming no ciclo 2 .31

Figura 9 - Diagrama de Ishikawa sobre distanciamento das famílias. .33

Figura 10 - Aplicação da técnica dos cinco porquês sobre a coordenação sobrecarregada

Figura 11 - Aplicação da técnica dos cinco porquês sobre a falta de atendimentos presenciais (secretaria)

Figura 12 - Diagrama de Ishikawa sobre reunião entre responsável do aluno com a direção da escola .35

Figura 13 - Diagrama de Ishikawa sobre falta de aulas on-line ...............................36

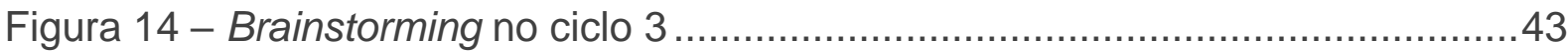

Figura 15 - Diagrama de Ishikawa sobre falta às aulas........................................45

Figura 16 - Aplicação da técnica dos cinco porquês para a alta demanda de perguntas sobre o setor financeiro

Figura 17 - Aplicação da técnica dos cinco porquês sobre a falta de organização e padronização dos arquivos enviados aos pais .46

Figura 18 - Diagrama de Ishikawa sobre presente do dia das mães. 47 Figura 19 - Fluxograma para a busca de um novo meio para fornecer as aulas online

Figura 20 - Fluxograma sobre alta possibilidade de perder arquivos com as atividades

Figura 21 - Fluxogramas da contratação da agenda eletrônica e da contratação do programa para fornecer aulas on-line 
Figura 22 - Diagrama de Ishikawa para falta de protocolo caso haja retorno das aulas.

\section{LISTA DE QUADROS}

Quadro 1 - Ferramentas da qualidade para cada fase da MASP .........................12

Quadro 2 - Técnicas utilizadas por fase da MASP ...............................................17

Quadro 3 - Turmas da instituição estudada ...................................................18

Quadro 4 - Características dos problemas no ciclo 1 .........................................21

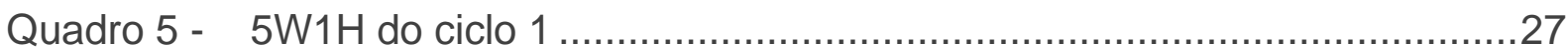

Quadro 6 - Características dos problemas no ciclo 2 ..........................................32

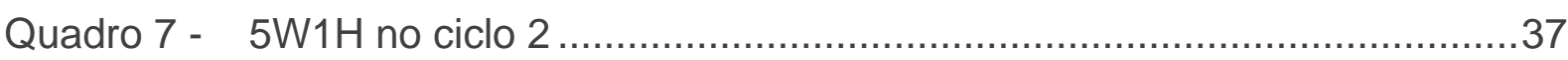

Quadro 8 - Características dos problemas no ciclo 3 ........................................44

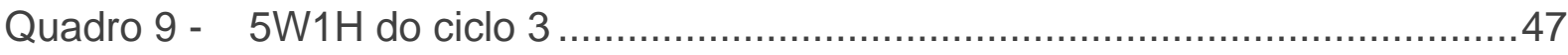

Quadro 10 - Relação de problema com a checagem ..........................................50

Quadro 11 - Características dos problemas no ciclo 4 …...................................52

Quadro 12 - Relação dos problemas com as causas raízes ....................................53

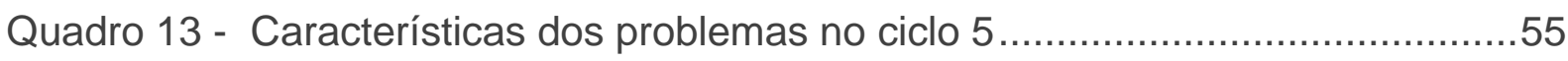

Quadro 14 - Características dos problemas no ciclo 6 .........................................59

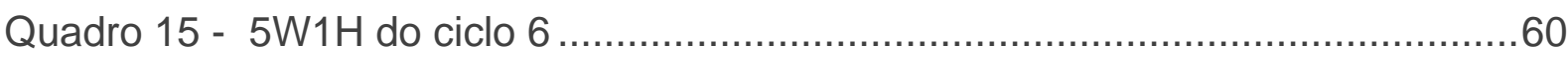

Quadro 16 - Características dos problemas no ciclo 7 ...........................................62

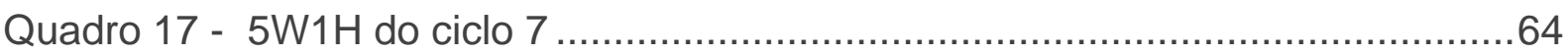

\section{LISTA DE TABELAS}

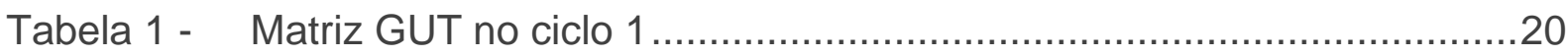

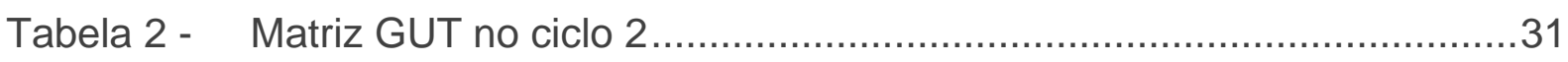

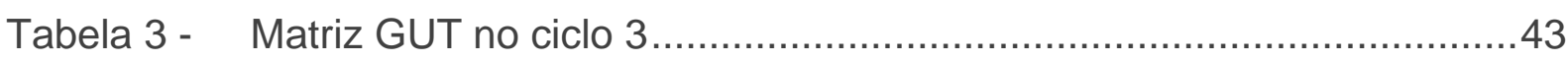




\section{LISTA DE ABREVIATURAS E SIGLAS}

CIT

CNE

GUT

MASP

MPMG

OMS

PROCON

SINEP-MG

TIC
Communication and Information Technologies

Conselho Nacional de Educação

Gravidade, Urgência e Tendência

Metodologia de Análise e Solução de Problemas

Ministério Público do Estado de Minas Gerais

Organização Mundial de Saúde

Programa Estadual de Proteção e Defesa do Consumidor

Sindicato das Escolas Particulares de Minas Gerais

Tecnologias da Informação e Comunicação 


\section{SUMÁRIO}

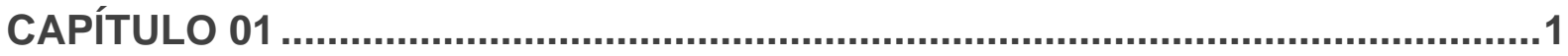

INTRODUÇÃO

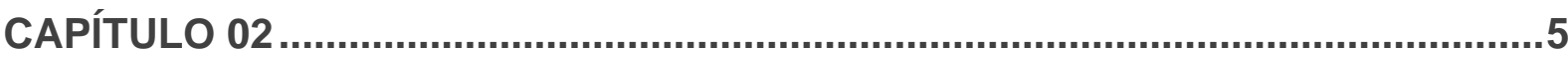
OBJETIVOS

CAPÍTULO 03 .6 REFERÊNCIAL TEÓRICO

CAPÍTULO 04 .13 METODOLOGIA

CAPÍTULO 05. .18 APRESENTAÇÃO E DISCUSSÃO DE RESULTADOS

CAPÍTULO 06. .66 CONSIDERAÇÕES FINAIS 


\section{CAPÍTULO 01 INTRODUÇÃO}

$\mathrm{Na}$ sociedade capitalista, cujo valor é considerando seu ponto principal, a educação se norteia por uma racionalidade ética, tendo em vista que o significado do ato de educar é tornar o aprendiz uma pessoa radicalmente humana (CAMPOS, 2010). Adicionalmente, devido às aparentes e constantes mudanças na sociedade globalizada, é crucial que as organizações promovam alternativas adequadas para que conquistem o sucesso da própria empresa (MENDES, 2013). Nessa direção, as escolas precisam buscar novos métodos de gestão para conciliar o sucesso no âmbito educativo e empresarial.

Alves (2006) e Kerbes (2018) apontam que a redução dos números de filhos por família, crises econômicas e a chegada de maior concorrência no ramo têm influenciado sobremaneira a crise nas escolas particulares no país. Já quanto à realidade nas escolas públicas, Oliveira, Duarte e Clementino (2017) apontam que o perfil da direção escolar pública mudou nos últimos tempos para uma gestão que busca por maiores resultados com menor emprego de recursos, além de ser uma gestão solucionadora de problemas. Ferreira e Pereira (2017), por sua vez, trazem outra dificuldade da direção encontrada em três escolas municipais no sul do país, que é a ausência da participação ativa, crítica e consciente dos alunos em discussões e tomada de decisões referentes ao processo político-pedagógico da escola.

Em resumo, as escolas públicas precisam de técnicas de gestão para acompanhar a realidade na qual elas vivem, com o foco na melhoria do ensino. Já as escolas particulares, com técnicas de gestão assertivas, precisam estar à frente para valorizar a escolha dos responsáveis em manter os filhos na rede privada, bem como o investimento realizado para se manterem vivas no mercado.

A situação dos gestores escolares se agravou durante a pandemia do novo coronavírus'. Por ser um vírus altamente contagioso, logo se disseminou rapidamente no planeta, deixando inúmeras vítimas fatais. Com isso, nos primeiros meses de 2020, a Organização Mundial de Saúde (OMS) recomendou o isolamento

${ }^{1} \mathrm{O}$ SAR-CoV2, popularmente conhecido como coronavírus, foi inicialmente identificado em Wuhan, na China, em 2019, e se espalhou ao redor do mundo causando uma pandemia. A Organização Mundial de Saúde nomeou a doença como Covid-19. 
social e medidas restritivas. Frente a esse cenário, o comitê extraordinário da Covid19, no uso da atribuição que Ihe foi conferida no art. 2 do Decreto n. 47.886, suspendeu as atividades presenciais nas escolas do estado de Minas Gerais (MINAS GERAIS, 2020).

Para minimizar o impacto da impossibilidade de fornecimento de aulas presenciais, o Conselho Nacional de Educação (CNE) autorizou a realização de atividades não presenciais para os alunos desde a Educação Infantil ao Ensino Médio. Diante dessa conjuntura, as escolas precisaram buscar alternativas para se adaptarem à nova realidade e atenuarem o impacto da impossibilidade de realização de aula presencial (SOUZA, 2020). Ou seja, a utilização de tecnologias da informação e comunicação (TIC) se tornou essencial diante do cenário atual, sendo importante na prática de ensino-aprendizagem dos alunos e como meio de comunicação com as famílias.

Estudos relacionados às TICs na área da educação demonstram a dificuldade de incorporá-las à prática pedagógica ${ }^{2}$.Vale ressaltar que a utilização de recursos tecnológicos é bem vista quando se minimizam os efeitos prejudiciais por meio de orientações e conscientização de seu uso (PASSERO; ENGSTER; DAZZI, 2016; TEIXEIRA, 2019).

Nesse sentido, Coutinho (2018) deixa claro que, diante da atual realidade brasileira, a dificuldade encontrada em escolas públicas em ofertar as TICs passa por questões como falta de preparo dos profissionais e de acessibilidade das escolas. Por sua vez, Henrique (2016) aponta que a realidade da utilização das TICs na rede particular está mais caracterizada por uma técnica instrumental e tecnicista do que em um processo de ensino-aprendizagem que objetiva uma aprendizagem mais significativa e colaborativa.

Mesmo diante de uma realidade volátil, como a enfrentada durante a pandemia, os gestores das escolas têm a missão de formar cidadãos fornecendo conteúdo de qualidade. Para tanto, é salutar a utilização de tecnologias conciliadas com uma gestão organizada com estratégias claras a serem seguidas. Em adição, para Dias e Melão (2009), as escolas, bem como grande parte das organizações atuais, buscam priorizar com frequência a qualidade, cujos conceitos têm sido estudados de forma valorizada.

${ }^{2}$ Cf. PASSERO; ENGSTER; DAZZI, 2016; HENRIQUE, 2016; TEIXEIRA, 2019. 
As organizações, de acordo com Lucinda (2010), são prejudicadas com a falta de qualidade não somente pelos custos que ela gera, mas também pela destruição da reputação frente aos clientes. Sendo assim, Dias e Melão (2009) atribuíram a importância dada à qualidade à necessidade de satisfazer os objetivos dos alunos e responsáveis, buscando saber os pontos positivos e negativos da escola. Adicionalmente, Carpinetti (2012) ressalta que para uma empresa adquirir uma boa reputação e se manter competitiva, conquistando um maior número de mercado, ela necessita priorizar a busca das necessidades de seus clientes quanto aos produtos e serviços.

Com a pandemia, a necessidade de comunicação entre a escola, os responsáveis dos alunos, alunos e colaboradores aumentou, dada a pressão devido ao isolamento social associada à utilização de recursos tecnológicos. Logo, as TICs se transformaram em um tópico relevante para a sobrevivência das escolas. Foi nesse contexto que surgiu este estudo, o qual visa analisar a implantação da metodologia de análise e solução de problemas (MASP) em uma escola particular no contexto da pandemia.

A MASP foi utilizada neste estudo pois, segundo Moraes, Borges e Sá (2010), essa técnica auxilia os gestores a estudar os processos, identificar os motivos ou causas de problemas encontrados e buscar soluções que os façam reduzir ou mesmo acabar. De forma complementar, Facci (2015) afirma que a MASP é baseada no ciclo $\mathrm{PDCA}^{3}$, sendo assim, a ferramenta permite orientar a empresa por meio de uma sequência de passos de modo a encontrar as causas e soluções de um problema com base em dados e fatos. As oito etapas que compõem a metodologia são: identificar, observar, analisar, elaborar plano de ação, executar, verificar e realizar treinamento e padronização.

Por fim, a MASP já foi utilizada em diferentes setores a fim de auxiliar nas tomadas de decisões, como no setor logística de uma rede varejista para amenizar excessos de estoque ${ }^{4}$; em empresas manufatureiras para reduzir a taxa de peças fora da especificação ou com defeitos ${ }^{5}$; no processo de expedição de uma agroindústria para fornecer melhor qualidade no produto, reduzir o número de

\footnotetext{
${ }^{3}$ Trata-se de uma metodologia que visa à melhoria contínua de processos e soluções em empresas por meio do ciclo planejar, fazer, checar e agir, do inglês, plan, do check e act.

${ }^{4}$ Cf. SANTOS, 2016.

${ }^{5} \mathrm{Cf}$. ANDRADE; RODRIGUES, 2017.
} 
devoluções nas vendas totais e no relacionamento com os clientes ${ }^{6} ; \mathrm{em}$ um processo industrial de paletização de garrafas PET em uma indústria de bebidas, tendo favorecido o aumento na produtividade? ${ }^{7}$.

A MASP, segundo Werkema (1995), é uma metodologia que auxilia a empresa a tomar decisões analisando os fatos e os dados do passado comprovados como causas raízes dos problemas.

Frente a toda essa conjuntura, o objetivo deste estudo foi aplicar a MASP em uma empresa de educação que atende crianças, como suporte na solução de problemas durante a pandemia do novo coronavírus. Para tanto, o estudo foi organizado da seguinte maneira: no capítulo 1 foi apresentada uma breve contextualização do tema; no capítulo 2, o objetivo geral e os objetivos específicos que nortearam a pesquisa; no capítulo 3 , referente ao referencial teórico, foram debatidos os temas sobre a pandemia e seus impactos nas escolas particulares, metodologia PDCA, ferramentas da qualidade, a MASP e suas características; o capítulo 4 foi dedicado à apresentação do percurso metodológico adotado; no capítulo 5 foram apresentados e discutidos os resultados obtidos; no capítulo 6 foram apresentadas as conclusões do estudo, as limitações e as propostas para futuros trabalhos; e, por fim, as referências utilizadas no embasamento da pesquisa. 


\section{CAPÍTULO 02 OBJETIVOS}

Foram apresentados no decorrer deste capítulo o objetivo geral e os objetivos específicos que nortearam esta pesquisa.

\subsection{Objetivo geral}

Aplicar a MASP em uma empresa de educação que atende crianças como suporte na solução de problemas durante a pandemia do novo coronavírus.

\subsection{Objetivos específicos}

Identificar, analisar e observar problemas a partir da ocorrência da pandemia da Covid-19 na empresa em questão utilizando ferramentas da qualidade;

Planejar ações afim mitigar problemas ocasionados em diferentes partes da empresa pelo isolamento social provocado pela pandemia do coronavírus;

Checar e padronizar as ações tomadas durante o estudo para garantir que elas não sejam prejudiciais e que melhorem o processo;

Refletir no final de cada ciclo MASP aplicado sobre os problemas ocasionados em reflexo à Covid-19, as ações tomadas, resultados obtidos e novos problemas a serem trabalhados. 


\section{CAPÍTULO 03 REFERÊNCIAL TEÓRICO}

Neste capítulo foram abordados temas relevantes para a continuidade deste estudo, como: a pandemia e seus impactos nas escolas particulares, a metodologia PDCA, ferramentas de qualidade e MASP.

\subsection{Pandemia e seus impactos nas escolas particulares}

A OMS, nos primeiros meses de 2020, declarou estado de pandemia em decorrência da disseminação global do novo coronavírus, causador da Covid-19. O vírus, altamente contagioso, disseminou-se rapidamente no planeta, deixando inúmeras vítimas fatais (SILVA, 2020; SOUZA, 2020).

Diante da realidade do isolamento social, a tecnologia passou a ser crucial no período da pandemia do novo coronavírus, pois, além de proporcionar uma funcionalidade no acompanhamento de resultados imediatos nos diferentes processos de ensino e aprendizagem, ela passou a ser utilizada como meio de contato com as famílias e de continuidade das atividades escolares por meio do ensino remoto (SILVA, 2020).

Silva e Silva (2020) realizaram um estudo nas escolas particulares de pequeno porte que trabalhavam no estado de São Paulo a fim de apresentar a importância da continuação da formação em cadeia criativa e a função social da escola de retomar valores universais, como empatia, alegria, solidariedade e afetos através do meio virtual. Alunos e professores perderam seu território, pais e/ou responsáveis passaram por dificuldades com a não presença física de suas crianças na escola, porém, por meio de alternativas em meios tecnológicos, a escola pôde se reinventar, transformar e encarar a reinvenção da educação e de si mesma de forma resiliente e mostrando o quão importante é para a sociedade (SILVA; SILVA, 2020).

\subsection{Metodologia PDCA}

O PDCA, também conhecido como Ciclo de Deming, é amplamente utilizado em diferentes setores das empresas (DINKAR, 2020). Kuliš e Hodžić (2020) apontam que ele pode ser utilizado como técnica de gestão da qualidade ou na 
empresa em geral. Adicionalmente, segundo Sharma, Grover e Sharma (2020), a implementação das ferramentas da qualidade tem fornecido muitos benefícios ao longo dos anos para as organizações manufatureiras e relatam também que vários pesquisadores e profissionais têm reconhecido sua significativa contribuição em empresas que possuem diferentes campos de atuação

De acordo com Deming (1990), o PDCA é um método que é aplicado em quatro etapas: planejamento (plan), que tem a função de definir uma meta e o planejamento para atingi-la; execução (do), que é a etapa de compreender o objetivo estabelecido na etapa anterior, de modo que todos os envolvidos no projeto entendam a meta e concordem com ela e com o planejamento; verificação (check), este é o momento de comparar os resultados encontrados com o objetivo que foi estabelecido na primeira etapa; e, por fim, ação (action), etapa responsável por transformar o plano que obteve o resultado positivo na nova maneira de realizar os processos.

\subsection{Ferramentas de qualidade}

Para Lemos Junior et al. (2019), as ferramentas de qualidade contribuem para uma maior compreensão do processo e são essenciais para identificar vulnerabilidades. Em adição, Silva et al. (2020) afirmam que a aplicação dessas ferramentas contribui significativamente para melhorar a gestão da qualidade e aumentar a proporção de cumprimento dos requisitos exigidos pela legislação da empresa.

\subsubsection{Brainstorming}

Bonnardel e Didier (2019) acreditam que a técnica brainstorming é capaz de buscar as habilidades criativas das pessoas envolvidas e que estimula o pensamento divergente ou convergente. Complementarmente, Danes, Mullikin e Lertwachara (2020) apontam que o brainstorming como mecanismo de ideias se torna ainda mais eficiente quando os participantes se abstêm de julgamentos, arriscam ideias ousadas e quando têm a oportunidade de se basearem nas ideias de outras pessoas

\subsubsection{Matriz GUT}


A matriz GUTé uma metodologia alternativa que permite classificar e priorizar problemas de modo a auxiliar na tomada de decisões da gestão (NOVASKl; FREITAS; BILLIG, 2020). Trata-se de uma matriz de priorização em tomadas de decisão que considera a gravidade, a urgência e a tendência dos problemas.

\subsubsection{Diagrama Ishikawa}

O diagrama de Ishikawa, também conhecido como diagrama de causa e efeito ou diagrama espinha de peixe, pode ajudar a identificar os principais erros e problemas em processos diversos. Segundo Moreira e Loos (2018), o diagrama é capaz de identificar as causas para um determinado efeito ou problema. Pacana e Siwiec (2020) apontam que o diagrama pode considerar seis áreas de atuação: mão de obra (man), processo ou método (method), máquina (machine), matéria-prima (materia), gestão (management) e meio ambiente (environment). Czerwińska, Dwornicka e Pacana (2020), por sua vez, considerando essas seis áreas, trocaram meio ambiente por medida (measurement), o que demonstra a flexibilização das áreas na aplicação do diagrama.

\subsubsection{Técnica dos cinco porquês}

A técnica interrogativa iterativa dos cinco porquês foi trazida pelo sistema Toyota de produção e trata-se de um método de perguntar cinco vezes, após definido exatamente o problema, o porquê de ele acontecer afim de buscar a causa raiz. Sendo assim, a técnica dos cinco porquês é um procedimento simples, porém eficiente, para entender as razões de um determinado problema (PERUSSI; ALVES; LIMA, 2020).

\subsubsection{W2H}

O 5W2H é um checklist de atividades específicas a serem desenvolvidas de modo a direcionar de forma clara e eficiente as etapas de um projeto. Os caracteres que nomeiam a metodologia se referem aos questionamentos que visam orientar as atividades: o que será feito (what), porque será feito (why), onde será feito (where), 
quando será feito (when), por quem será feito (who), como será feito (how), quanto irá custar (how much), portanto, $5 \mathrm{~W}$ e $2 \mathrm{H}$.

Para Perussi, Alves e Lima (2020), a ferramenta 5W2H é uma metodologia eficaz para organizar e planejar ações afim de dar suporte para soluções de problemas e tomadas de decisões mais eficientes, quer sejam antes ou depois de ocorrer o problema (ações preventivas ou corretivas). Vale ressaltar que atualmente existe o 5W3H. Ele é utilizado acrescentando mais uma análise, que é caracterizada, segundo Silva et al., (2020), pela descrição da eficácia da ação em termo de tempo (how long).

Devido a realidade da empresa e a necessidade de utilizar os recursos sem investimentos e a não necessidade de cálculo da eficiência em termos de tempo, pois as datas relevantes foram inseridas na etapa do quando (when), a ferramenta utilizada neste estudo foi o $5 \mathrm{~W} 1 \mathrm{H}$.

\subsubsection{Fluxograma}

Fluxogramas possibilitam uma visão ampla de cada etapa de um processo (TEIXEIRA et al., 2020). Essa metodologia também pode ser aplicada em diferentes áreas das empresas, como: atendimento em um centro de atenção psicossocial, fornecendo mais tranquilidade para as pessoas no dia a dia ${ }^{8}$; auxiliando no design de interfaces digitais de empresas ${ }^{9}$; e na identificação da sequência das fases do processo e dos correlacionados períodos de tempo necessários para a produção de estruturas metálicas por completo ${ }^{10}$.

\subsection{MASP}

De acordo com Oliveira e Hu (2018), MASP é a união do ciclo PDCA e as ferramentas de qualidade, caracterizando-se como uma metodologia vastamente empregada na análise e solução de problemas dos sistemas de gestão da qualidade. Sob ponto de vista dos mesmos autores, as principais recomendações da MASP é conhecer bem o efeito para extrair suas causas raízes, propor soluções, 
trabalhar com fatos e dados e eliminar decisões sem base no conhecimento concreto.

A Figura 1 traz a relação entre as etapas da MASP com o ciclo PDCA.

Figura 1 - Metodologia de solução de problemas (QC-Story).

\begin{tabular}{|c|c|c|c|}
\hline PDCA & $\begin{array}{l}\text { Fluxo- } \\
\text { grama }\end{array}$ & Fase & Objetivo \\
\hline & & Identificação do problema & $\begin{array}{l}\text { Definir claramente o problema e reconhecer } \\
\text { sua importância }\end{array}$ \\
\hline & & Observação & $\begin{array}{c}\text { Investigar as características específicas do } \\
\text { problema com uma visão ampla e sob vários } \\
\text { pontos de vista }\end{array}$ \\
\hline & & Análise & Descobrir as causas fundamentais \\
\hline & & Plano de ação & $\begin{array}{l}\text { Conceder um plano para bloquear as causas } \\
\text { fundamentais }\end{array}$ \\
\hline & & Ação & Bloquear as causas fundamentais \\
\hline & & Verificação & Verificar se o bloqueio foi efetivo \\
\hline & & (Bloqueio foi efetivo?) & \\
\hline & & Padronização & Prevenir contra o reaparecimento do problema \\
\hline & & Conclusão & $\begin{array}{l}\text { Recapitular todo o processo de solução do } \\
\text { problema para o trabalho futuro }\end{array}$ \\
\hline
\end{tabular}

Fonte: CAMPUS, 2004. (Adaptada pelo autor).

Conforme a Figura1, a etapa planejar (P) do PDCA é subdividida nas etapas de identificação do problema, observação, análise e plano de ação da MASP. Já a etapa que é chamada de fazer (D) equivale à etapa de ação. A etapa checar (C) equivale à fase seis de verificação. $E$, por último, a etapa agir (A) do PDCA é subdividida nas fases de padronização e conclusão da MASP.

\subsubsection{Aplicações da MASP em diferentes empresasijku}

Segundo o estudo de Lorenzon e Diedrich (2019) sobre a utilização da MASP em uma granja de suínos na cidade de Encantado, no Rio Grande do Sul, a metodologia auxiliou na redução do esmagamento de leitões, contribuindo na identificação deque esse problema representava 7,99 \% das mortes dos leitões. Por 
meio de ferramentas de qualidade foram sugeridas soluções de melhoria para a redução do número de mortes e, consequentemente, aumento da produtividade.

Em um estudo realizado por Oliveira, Albertin e Pontes (2018), essa metodologia auxiliou na melhoria do controle de estoque no atacado e varejo alimentício, reduzindo o impacto financeiro que era de $-2,59 \%$ do faturamento da empresa.

Andrade e Rodrigues (2017) estudaram os impactos da aplicação da MASP em uma empresa manufatureira situada em Lavras, no estado de Minas Gerais, a qual atuava na produção de máquinas de irrigação. Após a aplicação da metodologia, a empresa conseguiu reduzir a taxa de peças rejeitadas, o que colaborou com a redução do lead time da produção, além de ter fornecido maior controle e conhecimento nos padrões produtivos dos fornecedores.

Nicolao (2018) estudou a proposição e a implantação de melhorias de processo em uma indústria de papel e celulose do estado do Paraná utilizando a metodologia MASP, o que proporcionou para a empresa uma análise mais detalhada para o problema de transbordo em seus tanques. $O$ autor sugeriu a utilização da metodologia também em outras áreas da empresa em trabalhos futuros.

Em adição, Venanzi et al., (2018) estudaram uma empresa situada no estado de São Paulo no ramo de papel e celulose que utilizou a MASP para identificar os motivos mais relevantes das paradas e permitiu que a gestão da empresa se concentrasse nos aspectos mais importantes.

Trindade et al., (2019) estudaram a aplicação da MASP em busca da otimização do processo de atendimento de um pronto-socorro no primeiro atendimento ao paciente. Segundo os pesquisadores, a metodologia auxiliou na padronização do processo de classificação de urgência no atendimento dos pacientes com base na técnica do protocolo de classificação Manchester ${ }^{11}$.

O trabalho desenvolvido por Martins et al. (2019) em uma fábrica de móveis utilizando a MASP auxiliou na redução de falhas no processo de produção. Segundo os autores, o trabalho desenvolvido possuiu resultados satisfatórios e positivos, de modo que a empresa conseguiu reduzir $58 \%$ no número de pedidos de assistência

\footnotetext{
${ }^{11}$ Consiste na classificação por cores (vermelho, laranja, amarelo, verde e azul) dos pacientes que chegam ao hospital conforme o estado em que se encontram, determinando, desse modo, a gravidade do caso.
} 
técnica e, consequentemente, reduziu os gastos gerados pelas ocorrências de falhas em $49 \%$, gerando ganhos financeiros para a empresa.

\subsubsection{Síntese de metodologias e ferramentas utilizadas nas fases da MASP}

A MASP utiliza ferramentas da qualidade em suas fases que permitem organizar os dados e fatos e transformá-los em informações para auxiliar nas decisões, conforme apresentado no Quadro 1.

Quadro 1 - Ferramentas da qualidade para cada fase da MASP.

\begin{tabular}{l|c}
\hline \multicolumn{1}{c}{ Etapas da MASP } & Ferramentas \\
\hline 1. Identificação do & Brainstorming, entrevistas, diagrama de Pareto e gráfico de controle \\
problema & Fluxograma, análise de Pareto, folha de verificação \\
2. Observação do problema & prainstorming, diagrama de Ishikawa, diagrama de dispersão e 5 \\
3. Análise do problema & porquês \\
& $5 \mathrm{~W} 1 \mathrm{H}$ \\
4. Plano de ação & $5 \mathrm{~W} 1 \mathrm{H}$ \\
5. Ação & $5 \mathrm{~W} 1 \mathrm{H}$ \\
6. Verificação & - \\
7. Padronização & Diagrama de Pareto e gráfico de controle \\
8. Conclusão & Brate \\
\hline
\end{tabular}

Fonte: MORAIS et al., 2017.

Morais et al., (2017) ressaltam que não há limites de aplicações de ferramentas em cada etapa. 


\section{CAPÍTULO 04 METODOLOGIA}

Este estudo teve como o objetivo aplicar a metodologia de análise e solução de problemas em uma escola particular como suporte na solução de problemas durante a pandemia do novo coronavírus. A escola escolhida para aplicação da metodologia atendia crianças com idade inferior a 10 anos e superior a 2 anos e estava situada na região metropolitana de Belo Horizonte, Minas Gerais.

Primeiramente foi realizada uma revisão bibliográfica acerca da pandemia deCovid-19 e seus impactos nas escolas particulares. Em seguida, abordou-se a metodologia PDCA, assim como as ferramentas de qualidade utilizadas neste estudo e, por fim, a MASP, ou QC-Story. Como técnica e procedimento de análise foi realizada uma revisão bibliográfica abordando temas essenciais, sendo que as fontes utilizadas para adquirir as informações nessa etapa foram secundárias, pois foram utilizados artigos, livros, monografias e teses. Em contrapartida, as fontes captadas para o estudo de caso foram primárias, pois tais detalhes foram coletados na escola objeto da pesquisa ${ }^{12}$.

O tratamento dos resultados foi qualitativo, já que as informações coletadas na instituição eram dados necessários para a implementação e aperfeiçoamento de técnicas e habilidades importantes para a nova realidade escolar.

O estudo cobriu todo o período pandêmico da escola em 2020 e os primeiros meses de 2021, de modo a tentar contribuir com decisões assertivas em busca da qualidade do serviço. As etapas da MASP derivaram do ciclo PDCA, logo, para a MASP ser aplicada na escola foi necessário seguir as seguintes etapas: identificação do problema, observação, análise, plano de ação, ação, verificação, padronização e conclusão. Durante a aplicação da metodologia, a equipe responsável se reuniu semanalmente.

\subsection{Identificação do problema}

Para Maurici e Chaves (2016), problema é a diferença entre o resultado atual e o resultado almejado (meta). Sendo assim, o objetivo dessa etapa foi determinar

12 Vale frisar que o pesquisador autor desta dissertação exercia suas atividades diárias na escola objeto de estudo, tendo acesso às informações apresentadas. 
as metas a serem alcançadas, reconhecendo as possíveis perdas e ganhos existentes. Vale ressaltar que a ferramenta brainstorming e a matriz GUT foram selecionadas para fazer parte da identificação do problema nos setes ciclos que foram aplicados na empresa.

O brainstorming é utilizado como uma chuva de ideias de modo a fazer emergir os mais diferentes tipos de problemas que a empresa esteja passando. Segundo Oliveira e Hu (2018), o brainstorming é uma metodologia eficaz tanto para escolher problemas quanto para seu entendimento e resolução.

Para completar essa etapa foi utilizada a Matriz GUT, a qual seleciona dentre os problemas encontrados aqueles que devem ser priorizados. A margem de corte entre os problemas a serem priorizados e os problemas a serem observados varia de acordo com a capacidade de trabalhá-los em paralelo e com a necessidade de aplicação imediata, porém, neste estudo, optou-se por selecionar os problemas classificados em 75 ou mais como problemas a serem priorizados.

\subsection{Observação}

Para Campus (2004), o objetivo da observação é levantar as características do problema. Para essa etapa, as pessoas envolvidas na aplicação da MASP na escola determinaram que seria separado um momento da reunião para levantar características que o problema apresentava.

\subsection{Análise}

O objetivo da etapa de análise é estudar os problemas a fim de buscar suas causas raízes (MAURICl; CHAVES, 2016). Para isso, durante o período em que a escola esteve sob o impacto da pandemia em 2020, foram selecionadas duas ferramentas para análise do problema: a técnica dos cinco porquês e o diagrama de Ishikawa.

A técnica dos cinco porquês é utilizada para buscar a causa fundamental do problema por meio de perguntas sucessivas sobre o porquê de ele ter ocorrido (MAURICI; CHAVES, 2016). Essa metodologia é utilizada quando se tem uma causa considerada genérica e é necessário "cavar" ou afunilar para que se encontre a causa raiz do problema. 
Outra técnica utilizada no trabalho durante essa fase foi a construção do diagrama de Ishikawa. Esse diagrama é utilizado quando o resultado pode ser atribuído a múltiplas causas e pode ser analisado em seis categorias: mão de obra, matéria-prima, método, máquina, meio ambiente e medidas (OLIVEIRA; HU, 2018).

\subsection{Plano de ação}

O plano de ação é caracterizado pela organização do conjunto de ações que leva em conta o tempo de duração e os responsáveis pela execução (MAURICl; CHAVES, 2016). Nessa etapa foram utilizadas duas metodologias: o $5 \mathrm{~W} 1 \mathrm{H}$, para problemas mais complexos, e o fluxograma, quando um problema possuía um passo a passo bem definido.

\subsection{Ação}

A etapa ação é a hora de colocar o plano de ação em prática considerando os prazos determinados (MAURICI; CHAVES, 2016). Para este trabalho foi utilizado o fluxograma para auxiliar nas demandas consideradas mais complexas para compreensão e resolução pelas pessoas envolvidas.

\subsection{Verificação}

A etapa de verificação é o momento de comparar os resultados obtidos com as metas que foram estabelecidas (MAURICI; CHAVES, 2016). Essa etapa foi realizada por meio de reuniões semanais e com base no acompanhamento da direção durante o processo. Por esse motivo não foi utilizada nenhuma ferramenta.

\subsection{Padronização}

A etapa de padronização consiste no procedimento de estabelecer, utilizar e estimar padrões afim de verificar seu cumprimento, adaptação e efeitos (MAURICl; CHAVES, 2016). Sendo assim, essa etapa ocorreu basicamente com a orientação de continuidade da realização das ações com as pessoas envolvidas por meio de reuniões. 


\subsection{Conclusão}

A etapa da conclusão é o momento de refletir sobre como era o processo antes da MASP e como está atualmente afim de levantar os pontos positivos e negativos acerca do problema tratado.

Segundo Maurici e Chaves (2016), o PDCA é um processo dinâmico que se inicia com um problema e, ao encontrar a solução, já indica um novo problema a ser tratado. Sendo assim, a filosofia que o ampara é a melhoria contínua devido à criação de sucessivos ciclos. Nessa direção, a MASP, que derivou do ciclo PDCA, segue a mesma filosofia.

Neste trabalho, a MASP foi aplicada sete vezes, sendo que a cada vez era denominado um novo ciclo, conforme apresentado na Figura 2.

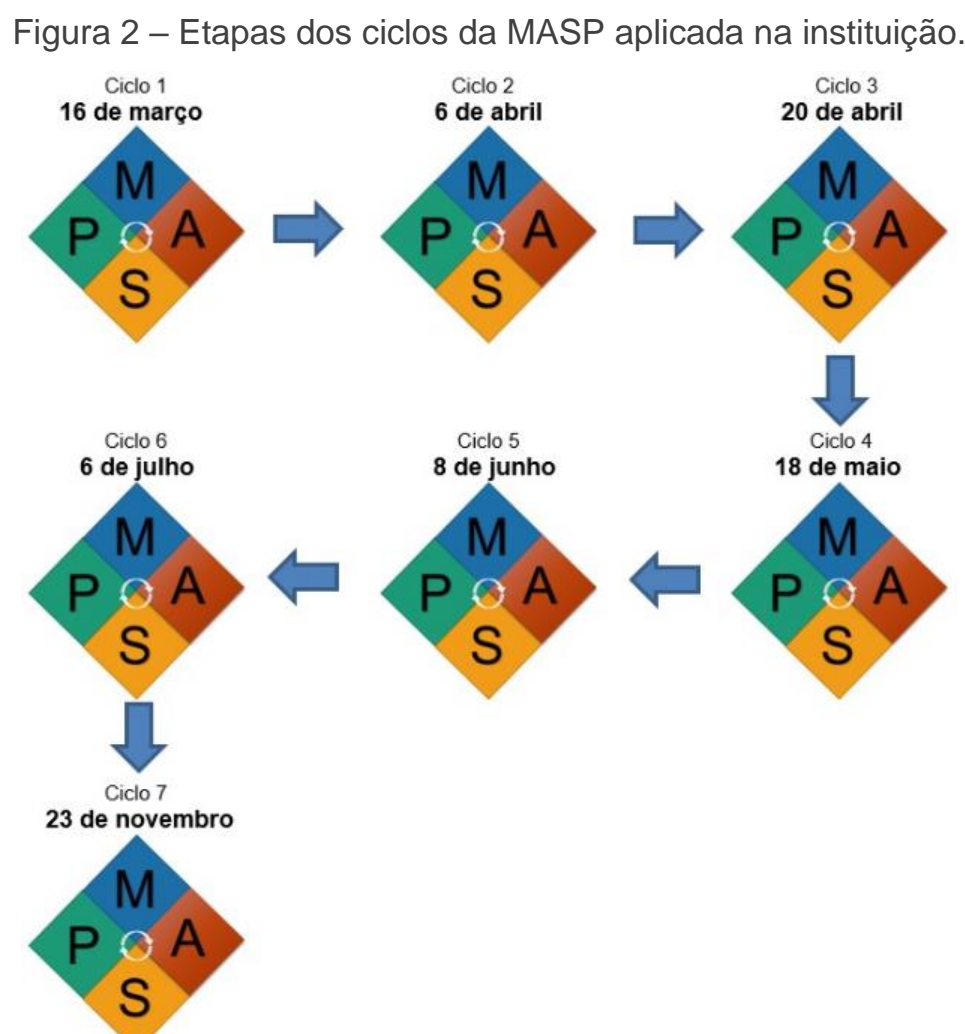

Fonte: Do autor, 2021.

De acordo com a sequência apresentada na Figura 2, o trabalho foi divido em ciclos da MASP, sendo que os inícios deles são respectivamente: 16 de março, 6 de abril, 20 de abril, 18 de maio, 8 de junho, 6 de julho e 23 de novembro, todos no ano de 2020. 
As ferramentas que foram utilizadas em cada fase das MASPs estão apresentadas no Quadro 2.

Quadro 2 - Técnicas utilizadas por fase da MASP.

\begin{tabular}{cc}
\hline Etapas do MASP & Ferramentas \\
\hline 1. Identificação do problema & Brainstorming, matriz GUT, reuniões \\
2. Observação do problema & Tabela para registro das características, reuniões \\
3. Análise do problema & Diagrama de Ishikawa, 5 porquês e reuniões \\
4. Plano de ação & Fluxograma, $5 \mathrm{~W} 1 \mathrm{H}$, reuniões \\
5. Execução & $5 \mathrm{~W} 1 \mathrm{H}$ e fluxograma \\
6. Verificação & Tabelas (checklist), reuniões \\
7. Padronização & Reuniões \\
8. Conclusão & Reuniões \\
\hline
\end{tabular}

Fonte: Do autor, 2021.

Vale ressaltar que foram selecionadas as metodologias, técnicas ou ferramentas nos primeiros ciclos MASP e nos demais foram mantidas as mesmas opções pelo fato de as pessoas envolvidas estarem familiarizadas com elas. 


\section{CAPÍTULO 05 \\ APRESENTAÇÃO E DISCUSSÃO DE RESULTADOS}

Foram apresentados no decorrer deste capítulo a contextualização da empresa e os resultados das aplicações dos sete ciclos MASP na instituição que foi alvo de estudo.

\subsection{Contextualização da empresa}

A instituição na qual o estudo foi desenvolvido foi fundada em 1979 e ficou conhecida na região pelo seu trabalho com foco no desenvolvimento de cada criança, pelo carinho e amor transpassado entre os colaboradores, famílias e alunos e por ser administrada por uma família. Vale ressaltar que a empresa foi comprada no ano de 2000 por uma família da mesma comunidade que apresentava ter os mesmos objetivos, atuando até os dias de hoje na direção da escola.

O foco no ensino tradicional combinado com técnicas de aprendizagem mais atuais atraiu a atenção e conquistou a confiança de muitas famílias moradoras do bairro da escola e seus adjacentes. No início do ano de 2021, a escola atendia em torno de 250 alunos com idades entre 2 e 10 anos, distribuídos nas turmas: maternal manhã, maternal 2 tarde, maternal 3 tarde, $1^{\circ}$ período manhã, $1^{\circ}$ período tarde, $2^{2}$ período manhã, $2^{\circ}$ período tarde, $1^{\circ}$ ano/9 tarde, $2^{\circ}$ ano/9 tarde, $3^{\circ}$ ano/9 manhã, $4^{\circ}$ ano/9 manhã e 5ำ ano/9 manhã. Essa distribuição está apresentada no Quadro 3.

Quadro 3 - Turmas da instituição estudada.

\begin{tabular}{c|c|c}
\hline Etapas & Agrupamento & Idade \\
\hline \multirow{4}{*}{ Educação Infantil } & Maternal & 2 e 3 anos \\
& $1^{\circ}$ período & 4 anos \\
& $2^{\circ}$ período & 5 anos \\
& $1^{\circ}$ ano $/ 9$ & 6 anos \\
Ensino & $2^{\circ}$ ano $/ 9$ & 7 anos \\
Fundamental & $3^{\circ}$ ano $/ 9$ & 8 anos \\
& $4^{\circ}$ ano $/ 9$ & 9 anos \\
& $5^{\circ}$ ano $/ 9$ & 10 anos \\
\hline
\end{tabular}

Fonte: Do autor, 2021.

Vale ressaltar que devido ao contexto educacional que a instituição apresenta, a escola sempre foi valorizada pelos atendimentos presenciais de pais 
por meio de reuniões e interferências no desenvolvimento dos alunos, sendo cada criança tratada com respeito quanto às individualidades inerentes à cada sujeito. Adicionalmente, os meios de contato entre família e escola se resumiam em telefone, agenda impressa e encontros presenciais.

Diante da nova realidade, adaptações tiveram que ser realizadas e novos desafios foram surgindo. Com isso, a escola precisou estabelecer um plano consistente e viável para manter suas funcionalidades e atividades afim de dar continuidade no desenvolvimento de seus alunos e também se manter financeiramente.

\subsection{Aplicação da MASP na escola}

Para analisar os problemas enfrentados na instituição de ensino no período da pandemia foi implementada a MASP e visto o passo a passo de cada etapa dos problemas. Após a resolução ou mitigação dos problemas foi iniciado um novo ciclo.

\subsubsection{MASP ciclo 1}

No dia 16 de março de 2020 foram suspensas as aulas presenciais por motivo de segurança e, com isso, foram gerados novos problemas que foram somados com as demandas já existentes. Assim, o primeiro ciclo da MASP foi iniciado no mesmo dia.

\subsubsection{Identificação do problema}

Para auxiliar na identificação dos problemas foi realizada a técnica de brainstorming na reunião entre a direção e a coordenação da empresa. Essa técnica foi selecionada por ter sido entendida pelos colaboradores como uma oportunidade de opinarem livremente, de pensarem alternativas diferentes daquelas que são levantadas durante as tarefas do dia a dia, de relacionarem problemas em cima de problemas, pontuarem os questionamentos de pais, alunos, professores e demais colaboradores da escola, além de ser um momento de reflexão nas falhas também da direção e coordenação. A Figura 3 traz os problemas observados após aplicação da técnica de brainstorming. 
Figura 3 - Brainstorming no ciclo 1.
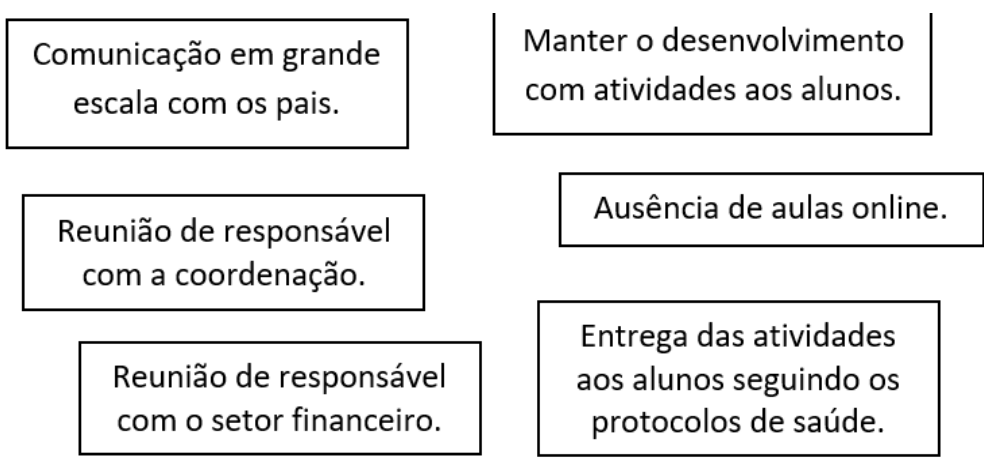

Atendimentos presenciais.

Entrega das atividades aos alunos seguindo os protocolos de saúde.

Compra de equipamentos de segurança.

Reunião de responsável com a direção.

Fonte: Do autor, 2021.

Após levantar os problemas da escola foi utilizada a matriz GUT. Ela foi considerada uma metodologia de fácil adesão e levou em consideração a opinião da direção e coordenação da escola, além de analisar as opiniões dos stakeholders ${ }^{13}$. A matriz GUT relaciona os parâmetros gravidade $(G)$, urgência $(U)$ e tendência $(T)$ dos problemas. Sendo assim, os valores dos parâmetros foram indicados na mesma reunião em que foi realizado o brainstorming.

A Tabela 1 traz a representação da primeira matriz GUT elaborada.

Tabela 1 - Matriz GUT no ciclo 1.

\begin{tabular}{|c|c|c|c|c|c|}
\hline Problemas & G & $\mathrm{U}$ & $\mathbf{T}$ & Total & \\
\hline Comunicação em grande escala com os pais & 5 & 5 & 5 & 125 & \\
\hline Manter o desenvolvimento com atividades aos alunos & 4 & 5 & 5 & 100 & 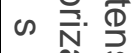 \\
\hline $\begin{array}{l}\text { Entrega das atividades aos alunos seguindo os protocolos de } \\
\text { saúde }\end{array}$ & 4 & 4 & 5 & 80 & صి \\
\hline Atendimentos presenciais & 3 & 3 & 2 & 18 & \\
\hline Compra de equipamentos de segurança & 3 & 2 & 2 & 12 & \\
\hline Reunião de responsável com a direção & 1 & 1 & 1 & 1 & D \\
\hline Reunião de responsável com a coordenação & 2 & 1 & 1 & 2 & ڤ్ \\
\hline Reunião de responsável com o setor financeiro & 3 & 2 & 1 & 6 & D \\
\hline Aulas on-line & 1 & 1 & 1 & 1 & \\
\hline
\end{tabular}

Fonte: Do autor, 2021.

De acordo com a análise realizada, os problemas de comunicação em grande escala com os pais, manter o desenvolvimento com atividades aos alunos e entrega das atividades aos alunos seguindo os protocolos de saúde deveriam ser tratados naquele momento. O próximo passo foi a observação.

\footnotetext{
${ }^{13}$ Trata-se das pessoas interessadas nas demandas em questão, como, por exemplo, professores, funcionários do administrativo, alunos, responsáveis pelos alunos, entre outros.
} 


\subsubsection{Observação}

A etapa de observação é o momento de analisar os atributos de cada demanda que foi considerada como prioridade na matriz GUT. Sendo assim, foi elaborado um quadro levantando o porquê do item ser um problema, bem como algumas características específicas de cada item, conforme apresentado no Quadro 4.

Quadro 4 - Características dos problemas no ciclo 1.

\begin{tabular}{l|l}
\hline \multicolumn{1}{c|}{ Problemas } & \multicolumn{1}{c}{ Características específicas } \\
\hline $\begin{array}{l}\text { Comunicação em } \\
\text { grande escala com } \\
\text { os pais }\end{array}$ & $\begin{array}{l}\text { Com a falta do contato presencial, a necessidade de comunicação } \\
\text { com os pais aumenta, e a instituição não possui retrospecto de } \\
\text { comano utilizando recursos tecnológicos anteriormente. Logo, } \\
\text { deve ser selecionado um meio rápido, eficaz e de fácil acesso para a } \\
\text { escola e a família } \\
\text { O desenvolvimento dos alunos não pode parar, esse é o } \\
\text { compromisso da escola com cada família }\end{array}$ \\
$\begin{array}{l}\text { Manter o } \\
\text { desenvolvimento } \\
\text { com atividades aos } \\
\text { alunos }\end{array}$ & $\begin{array}{l}\text { Durante esse período ainda não havia uma legislação quanto ao } \\
\text { trabalho dos professores, pois, até então, deveriam cumprir a carga } \\
\text { horária das aulas posteriormente. Sendo assim, a direção e a }\end{array}$ \\
$\begin{array}{l}\text { Entrega das } \\
\text { coovisão para cada turma da escola }\end{array}$ \\
$\begin{array}{l}\text { atividades aos } \\
\text { alunos seguindo } \\
\text { os protocolos de } \\
\text { saúde }\end{array}$ & $\begin{array}{l}\text { A escola necessita que a entrega seja segura e tranquila para que } \\
\text { tenha maior adesão dos alunos }\end{array}$ \\
\hline
\end{tabular}

Fonte: Do autor, 2021.

Levantadas as principais características dos problemas previamente selecionados, a próxima etapa da MASP foi analisar de maneira mais criteriosa essas demandas.

\subsubsection{Análise}

O objetivo principal da etapa de análise foi descobrir as causas de cada problema. Para tanto foi elaborado um diagrama de Ishikawa e a técnica dos cinco porquês foi utilizada duas vezes. 


\subsection{Comunicação em grande escala com os pais}

O problema com a comunicação em grande escala com os pais foi analisado utilizando o diagrama de Ishikawa. Essa metodologia foi escolhida por ser um problema que envolve uma mudança radical no sistema de informação da escola e porque as pessoas envolvidas na reunião acreditarem haver diferentes causas raízes. A Figura 4 apresenta as causas raízes de acordo com o diagrama de Ishikawa para a demanda de comunicação em grande escala com os pais.

Figura 4 - Diagrama de Ishikawa sobre a falta de comunicação em grande escala com os pais.

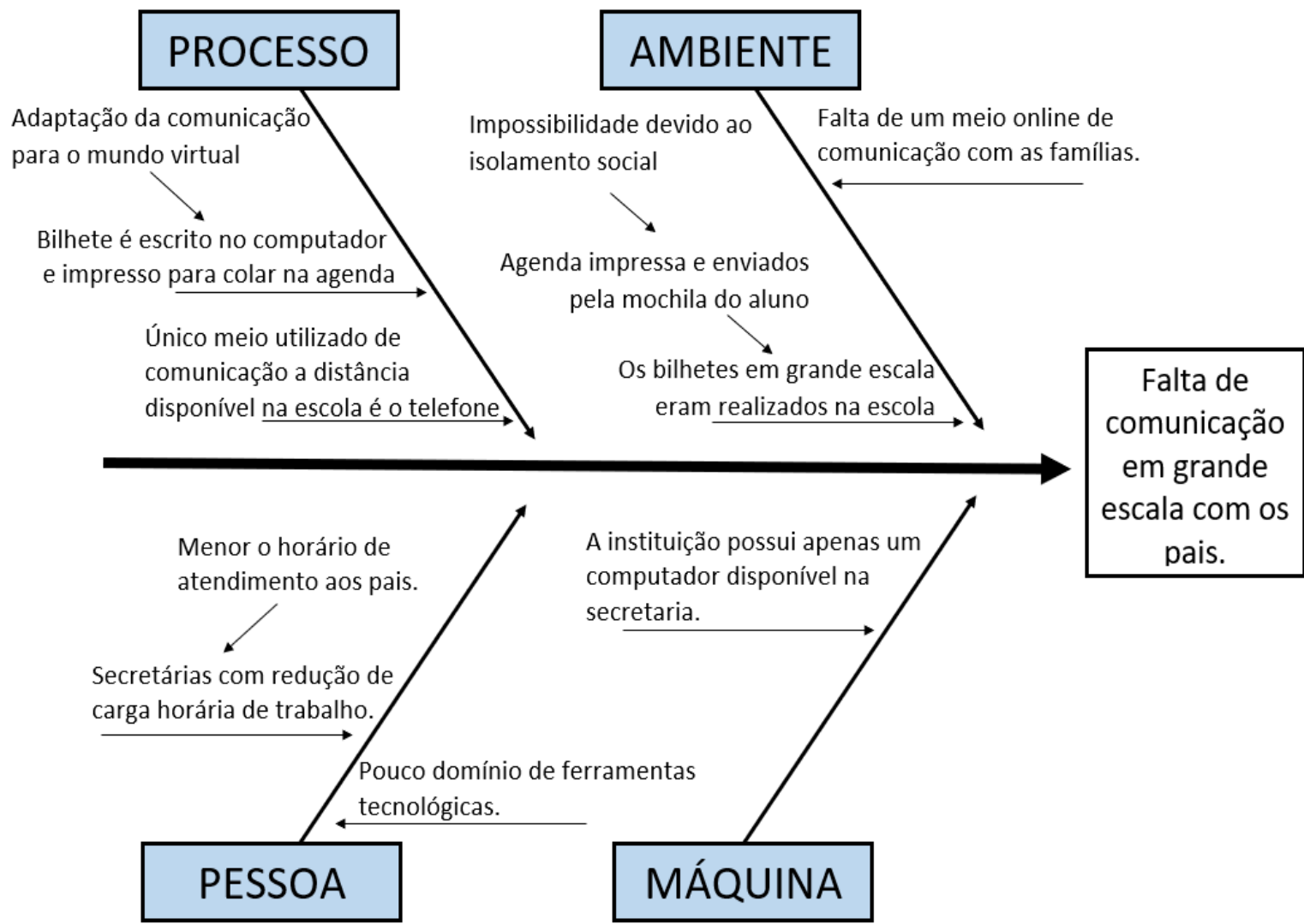

Fonte: Dos autores, 2021.

As causas raízes do primeiro problema levantadas a partir do diagrama foram: adaptação da comunicação para o mundo virtual, seleção e treinamento dos colaboradores para a nova função, secretárias com carga horária reduzida e secretaria possuía apenas um computador disponível. Essas causas foram somadas com a causa raiz do próximo problema, analisado a seguir. 
5.2.1.3.2 Manter o desenvolvimento com atividades aos alunos

Como a demanda mostrou ser mais genérica e a causa raiz aparentou ser mais específica, a direção e a coordenação da escola optaram por utilizar a técnica dos cinco porquês, a qual possibilita destacar apenas uma causa raiz por meio de uma análise pontual do problema.

A Figura 5 apresenta a análise realizada com a demanda de manter o desenvolvimento com atividades aos alunos.

Figura 5 - Aplicação da técnica dos cinco porquês sobre manter o desenvolvimento com atividades aos alunos.

Elaborar atividades de revisão com qualidade

As professoras elaboram as atividades, porém a lei não deixou claro se elas poderiam fazê-lo

Elas deverão cumprir carga horária posteriormente

A escola tem que cumprir a mesma carga horária de aula durante o ano

A escola necessita de alguém para elaborar atividades que sejam atrativas e com qualidade para os alunos

Fonte: Do autor, 2021.

Seguindo a análise dos cinco porquês realizada, a causa raiz que foi somada às outras causas do primeiro problema foi: a escola necessitava de alguém para elaborar atividades que fossem atrativas e com qualidade para os alunos. E, para finalizar essa etapa, foi analisado o último problema, apresentado no tópico a seguir.

\subsection{Entrega das atividades aos alunos seguindo os protocolos de saúde}

Devido ao fato de a entrega das atividades aos alunos seguindo os protocolos de saúde se tratar de um problema considerado amplo e que necessitava ser afunilado, ele foi analisado com a técnica dos cinco porquês, conforme Figura 6. 
Figura 6 - Aplicação da técnica dos cinco porquês sobre a entrega das atividades aos alunos seguindo os protocolos de saúde.

Entrega das atividades aos alunos seguindo os protocolos de saúde

Falta de adesão na realização das atividades

Perder a confiança dos pais com a escola

Pouco desenvolvimento dos alunos. Necessidade intervenção de qualidade e

atrativa para melhorar o desenvolvimento dos alunos com as atividade de

aperfeiçoamento pedagógico e demonstrar a importância aos pais da intervenção

para aderirem a busca das atividades na escola

Necessidade de campanha para realizar as atividades e demonstrar segurança nas

entregas presenciais

A escola necessita de alguém para elaborar atividades que sejam atrativas e com

qualidade para os alunos, além de precisar demonstrar segurança com protocolos contra a Covid-19 nas entregas

Fonte: Do autor, 2021.

Após analisar o último problema, a causa raiz foi igual a anterior, logo, a necessidade de alguém para elaborar atividades que fossem atrativas e com qualidade para os alunos era indispensável naquele momento. Adicionalmente, foi observado ser preciso demonstrar segurança com protocolos contra a Covid-19 nas entregas das atividades. Assim, finalizou-se a etapa de análise. O próximo passo da MASP foio plano de ação.

\subsubsection{Plano de ação}

A etapa plano de ação tem o objetivo de elaborar um plano a ser seguido para minimizar as causas raízes dos problemas analisados na etapa anterior, que foram: i) adaptação da comunicação para o meio virtual; ii) seleção e treinamento das colaboradoras para a nova função; iii) secretárias com carga horária reduzida; iv) secretaria possui apenas um computador disponível; e v) necessidade de alguém para elaborar atividades que fossematrativas e com qualidade para os alunos.

\subsection{Adaptação da comunicação para o meio virtual}

Nessa etapa foi utilizado o fluxograma por ser uma técnica considerada pelos envolvidos acessível, prática e rápida, pois a escola estava no último dia de aula presencial e a direção precisava colar as orientações nas agendas dos alunos, conforme era realizado antes do isolamento social. 
A equipe de direção e o pesquisador se reuniram a fim de buscar a redução ou resolução do problema de adaptação da comunicação para o meio virtual. Como foi rápido determinar o passo a passo, as pessoas envolvidas consideraram necessário apenas elaborar o passo a passo por meio de um fluxograma, conforme apresentado na Figura 7.

Figura 7 - Fluxograma para adaptação da comunicação para o meio virtual.

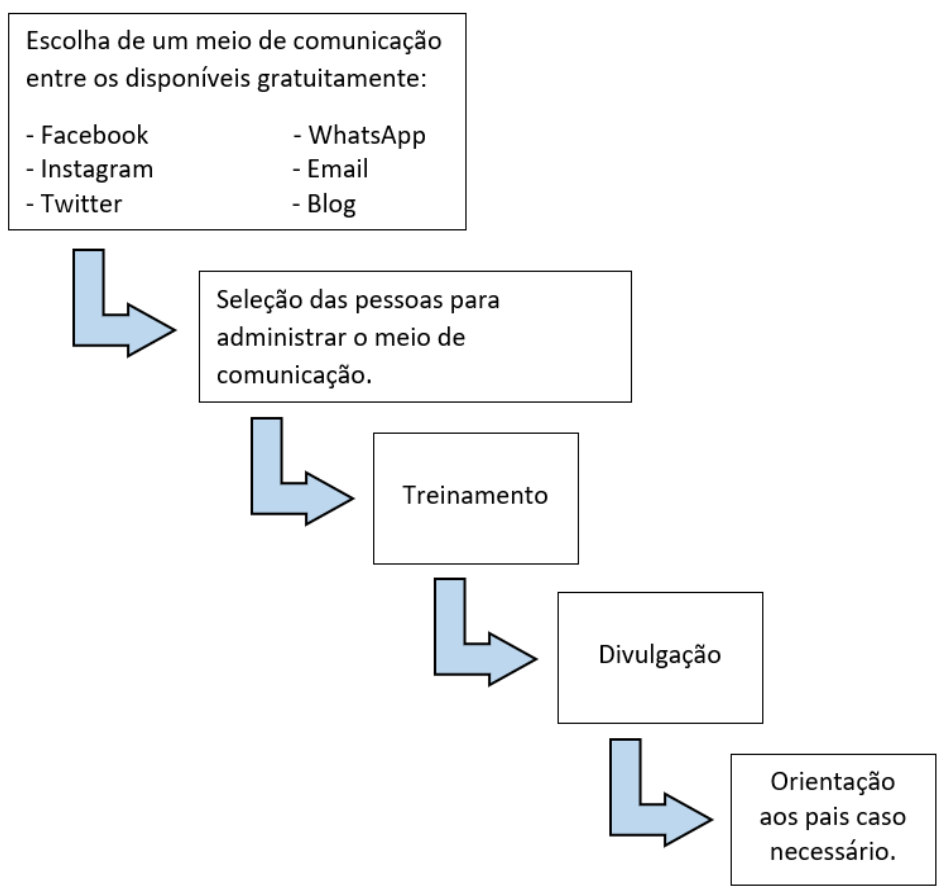

Fonte: Do autor, 2021.

A técnica utilizada proporcionou uma visão geral da mitigação do problema, podendo ser observado que os passos adotados eram necessários devido à escola não utilizar meios digitais anteriormente.

\subsection{Seleção e treinamento das colaboradoras para a nova função}

Para a seleção e treinamento das colaboradoras para a nova função foi realizada uma reunião entre os membros da direção da escola, tendo sido analisados os seguintes tópicos: i) disponibilidade; ii) habilidade; e iii) redistribuição de outras funções. Assim, uma das duas secretárias foi selecionada.

O treinamento foi realizado em paralelo com os atendimentos devido à falta de tempo hábil para realizá-lo. Vale ressaltar que a direção ficou responsável por acompanhar todas as ações da secretária relacionada ao meio de comunicação selecionado. 


\subsection{Secretárias com carga horária reduzida}

O planejamento para a demanda da redução da carga horária das secretárias envolveu a organização do horário de atendimento na escola. A princípio, os pais só seriam atendidos na escola uma vez na semana até o retorno presencial. $O$ dia selecionado foi a segunda-feira no horário de $9 \mathrm{~h}$ às $11 \mathrm{~h}$ e de $13 \mathrm{~h}$ às $16 \mathrm{~h}$. Nos demais dias, a direção atenderia os pais de maneira remota.

\subsection{Secretaria possui apenas um computador disponível}

Para solucionara dificuldade de haver apenas um computador disponível na secretaria, a direção alterou suas tarefas diárias concentrando todas as atividades no computador no período que a secretária não estivesse atendendo os pais. Caso houvesse necessidade de utilização do computador pela direção nos horários em que a secretária estivesse no computador, deveriam realizar uma escala.

5.2.1.4.5 A escola necessita de alguém para elaborar atividades que sejam atrativas e com qualidade para os alunos, além de precisar demonstrar segurança com protocolos contra a Covid-19 nas entregas

O problema em questão foi dividido novamente para a necessidade de alguém para elaborar atividades que fossem atrativas e com qualidade para os alunos e entrega com segurança. Sendo assim, as pessoas envolvidas julgaram ser mais eficaz pelo fato de se tratarem de setores diferentes da escola, como coordenação e secretaria.

Para tratar dos dois tópicos selecionados foi elaborado um plano de ação utilizando a técnica $5 \mathrm{~W} 1 \mathrm{H}$. Essa metodologia foi escolhida por ser considerada mais norteadora, destrinchando tópicos coerentes para os problemas envolvidos e para determinar as seguintes variáveis: i) tempo para trabalho; ii) profissionais envolvidos; iii) porque o tópico é um problema ou porque a ação pode ajudar a minimizar ou acabar com o problema; e iv) como seriam realizadas as ações de soluções.

O Quadro 5 apresenta a divisão e organização para a mitigação dos dois problemas analisados. 
Quadro 5-5W1H do ciclo 1.

\begin{tabular}{|c|c|c|c|c|c|c|}
\hline \multirow{2}{*}{$\begin{array}{c}\text { Solução / } \\
\text { o que } \\
\text { (What) }\end{array}$} & \multicolumn{2}{|c|}{$\begin{array}{l}\text { Quando } \\
\text { (When) }\end{array}$} & \multirow{2}{*}{$\begin{array}{l}\text { Onde } \\
\text { (Where) }\end{array}$} & \multirow[t]{2}{*}{ Quem (Who) } & \multirow{2}{*}{$\begin{array}{c}\text { Por que } \\
\text { (Why) }\end{array}$} & \multirow[t]{2}{*}{ Como (How) } \\
\hline & Início & Fim & & & & \\
\hline $\begin{array}{l}\text { Necessidade } \\
\text { de alguém } \\
\text { para elaborar } \\
\text { atividades } \\
\text { que fossem } \\
\text { atrativas e } \\
\text { com } \\
\text { qualidade } \\
\text { para os } \\
\text { alunos } \\
\end{array}$ & 19/03 & $22 / 03$ & Biblioteca & $\begin{array}{l}\text { Coordenação } \\
\text { e direção }\end{array}$ & $\begin{array}{c}\text { Incerteza } \\
\text { perante a lei } \\
\text { se as } \\
\text { professoras } \\
\text { poderiam } \\
\text { elaborar as } \\
\text { atividades }\end{array}$ & $\begin{array}{c}\text { - Utilizando livros } \\
\text { disponíveis na } \\
\text { biblioteca }\end{array}$ \\
\hline $\begin{array}{c}\text { Entrega com } \\
\text { segurança }\end{array}$ & 23/03 & $03 / 04$ & $\begin{array}{c}\text { Portaria da } \\
\text { escola }\end{array}$ & $\begin{array}{c}\text { Secretaria e } \\
\text { direção }\end{array}$ & $\begin{array}{c}\text { Manter a } \\
\text { credibilidade } \\
\text { da escola e } \\
\text { estar em } \\
\text { contato com } \\
\text { os pais }\end{array}$ & $\begin{array}{l}\text { - Barreira de } \\
\text { isolamento no } \\
\text { atendimento, uso } \\
\text { de álcool em gel e } \\
\text { uso de máscara } \\
\text { para entrega das } \\
\text { atividades } \\
\text { impressas; } \\
\text { - Envio de } \\
\text { atividades por e- } \\
\text { mail criado para } \\
\text { esse fim para os } \\
\text { responsáveis que } \\
\text { optarem por } \\
\text { receber as } \\
\text { atividades em } \\
\text { casa; } \\
\text { - Ligações para os } \\
\text { responsáveis que } \\
\text { não tiveram acesso } \\
\text { às atividades. }\end{array}$ \\
\hline
\end{tabular}

Fonte: Do autor, 2021.

Frente aos problemas apresentados, as ações previstas foram: i) utilizar livros disponíveis na biblioteca; ii) montar uma barreira de isolamento no atendimento; iii) utilizar e disponibilizar o álcool em gel; iv) utilizar máscara na entrega das atividades impressas; v) organizar o envio de atividades por e-mail para os responsáveis que optassem por receber as atividades em casa; e v) realizar ligações para os responsáveis que não tivessem acesso às atividades. Uma vez analisado e elaborado o plano de ação de acordo com cada demanda, o próximo passo foi a execução.

\subsubsection{Execução}

A etapa de execução foi o momento de colocar em prática o planejamento realizado de cada problema. Para gerar uma visão ampla da execução e aproximá-la 
mais da realidade, optou-se, para essa etapa, pela realização da descrição de maneira discursiva.

5.2.1.5.1 Adaptação da comunicação para o meio virtual

O primeiro problema foi tratado de acordo com as seguintes ações:

- Seleção do aplicativo: devido à maior praticidade, facilidade, domínio do aplicativo pelos colaboradores da escola e acessibilidade das famílias, o aplicativo Instagram foi selecionado como meio de comunicação;

- Como foi realizada a adoção do aplicativo: a página da escola foi criada e o endereço foi enviado aos pais no último bilhete impresso colado na agenda. Além disso, foi colado um bilhete com orientação no portão da escola e as secretárias ligaram para os responsáveis pelos alunos que não estavam presentes na escola no dia de aula presencial;

- Processo de atendimento pelo aplicativo: a princípio, a direção da escola assumiu os atendimentos pelo aplicativo a fim de estar mais próxima dos pais dos alunos. Inicialmente, os atendimentos foram realizados 24 horas por dia, incluindo sábados, domingos e feriados. A cada novidade divulgada nas mídias, a escola recebia várias solicitações de esclarecimentos pelo Instagram ou pelo telefone da escola;

- Intervenções: foram necessárias algumas orientações aos responsáveis que não utilizavam o aplicativo pela direção e secretaria. A escola prestou os esclarecimentos e atendimentos por telefone e presencialmente de forma a auxiliálos.

5.2.1.5.2 Seleção e treinamento das colaboradoras para a nova função

O treinamento das colaboradoras para a nova função foi realizado com orientações de atendimento, pois a secretária selecionada já tinha habilidade com o aplicativo. Em contrapartida, a direção ficou responsável por acompanhar e auxiliar nas respostas por ser um momento bastante delicado para a instituição.

\subsection{Secretárias com carga horária reduzida}

Os atendimentos aos pais foram reduzidos para o horário no qual as duas secretárias poderiam estar trabalhando, que foi de $13 \mathrm{~h}$ às $16 \mathrm{~h}$ apenas às segundasfeiras. 
5.2.1.5.4 Secretaria possui apenas um computador disponível

A fim de mitigar o problema de haver apenas um computador disponível na escola foi organizada uma escala de horário para cada pessoa utilizar o computador de acordo com a necessidade, como, por exemplo, tirar notas ficais, elaborar documentos que mantêm a organização da secretaria e atendimentos de maneira geral.

5.2.1.5.5 A escola necessita de alguém para elaborar atividades que sejam atrativas e com qualidade para os alunos, além de precisar demonstrar segurança com protocolos contra a Covid-19nas entregas das atividades

As elaborações das atividades foram realizadas na biblioteca da escola, tendo a coordenação e a direção preparado um aparato de atividades de revisão do início do ano letivo. Adicionalmente, a direção tirou uma fotocópia das atividades para todos os alunos da escola de acordo com a idade e ciclo de curso.

Quanto à entrega das atividades de maneira segura foram realizadas as seguintes ações: i) campanha de resolução das atividades por meio do Instagram da escola com postagens de incentivo e valorização da realização das atividades; ii) para fornecer acessibilidade aos alunos das famílias que optaram por não sair de casa foi feito o envio das atividades por meio de um link de um drive criado por $e$ mail ou Instagram; e iii) foi feita uma lista de controle de recebimento das atividades, tendo a secretaria realizado ligações àqueles que não as receberam orientando e valorizando a realização das mesmas.

\subsubsection{Verificação}

A verificação das mensagens enviadas aos pais pelo Instagram foi realizada por meio do acompanhamento das mensagens pela direção. Houve necessidade de realizar reuniões semanais entre a direção e a coordenação para avaliar e acompanhar as decisões da MASP.

Já a verificação da acessibilidade das informações enviadas pela escola foi realizada por checklist, uma a técnica simples, mas robusta. Foram feitas ligações para a casa de cada um dos alunos perguntando sobre o acesso às informações e 
sobre como estavam os alunos. Essa lista foi utilizada para controle de todos os contatos iniciais realizados e também para o controle de recebimento das atividades presenciais ou on-line. Dessa forma, a escola tinha o controle da realização das atividades entre as entregas das semanas.

\subsubsection{Padronização}

Devido à alta demanda de respostas no Instagram e para que não houvesse divergências de informações nos atendimentos realizados pela secretária e direção foram criadas respostas padrões, as quais eram personalizadas com o nome de cada responsável e/ou criança, além do nome do funcionário que estava respondendo. Outra padronização foi em relação às atividades elaboradas. A direção da escola auxiliou com as atividades da Educação Infantil e ficou responsável pelas atividades do $1^{\circ} \mathrm{e}$ 2ำano do Ensino Fundamental. Já a coordenação auxiliou na elaboração das atividades da Educação Infantil e ficou responsável pela elaboração das turmas do $3^{\circ}, 4^{\circ}$ e $5^{\circ}$ ano do Ensino Fundamental. As entrega serão realizadas semanalmente.

\subsubsection{Conclusão}

A implementação do Instagram como meio de comunicação foi considerada um sucesso por ambas as partes - escola e família. A nova demanda nesse item foi gerar uma arte mais profissionalizada para a página da escola, pois o Instagram também funcionaria como vitrine para novos alunos.

As atividades foram bem vistas pelos responsáveis dos alunos, pois a escola ofereceu um acompanhamento pedagógico de qualidade mesmo antes de uma semana de isolamento social. Já em relação à entrega de atividades, os responsáveis dos alunos agradeceram e elogiaram a disponibilidade de a entrega poder ser feita tanto de forma presencial quanto virtual.

Ao término do primeiro ciclo da MASP, a escola identificou outros problemas devido à nova realidade de isolamento que perdurou por mais tempo. Com isso, a pesquisa continuou com um novo ciclo da MASP, que foi iniciado no dia 6 de abril de 2020. 
No dia 6 de abril de 2020 foi realizada uma nova reunião entre a coordenação e a direção para dar início ao novo ciclo da MASP de modo a sanar as demandas desse período.

\subsubsection{Identificação do problema}

Para auxiliar na identificação dos problemas foi realizada a técnica de brainstorming na reunião entre a direção e a coordenação da empresa, tendo sido levantados os problemas apontados na Figura 8.

Figura 8 - Brainstorming no ciclo 2.
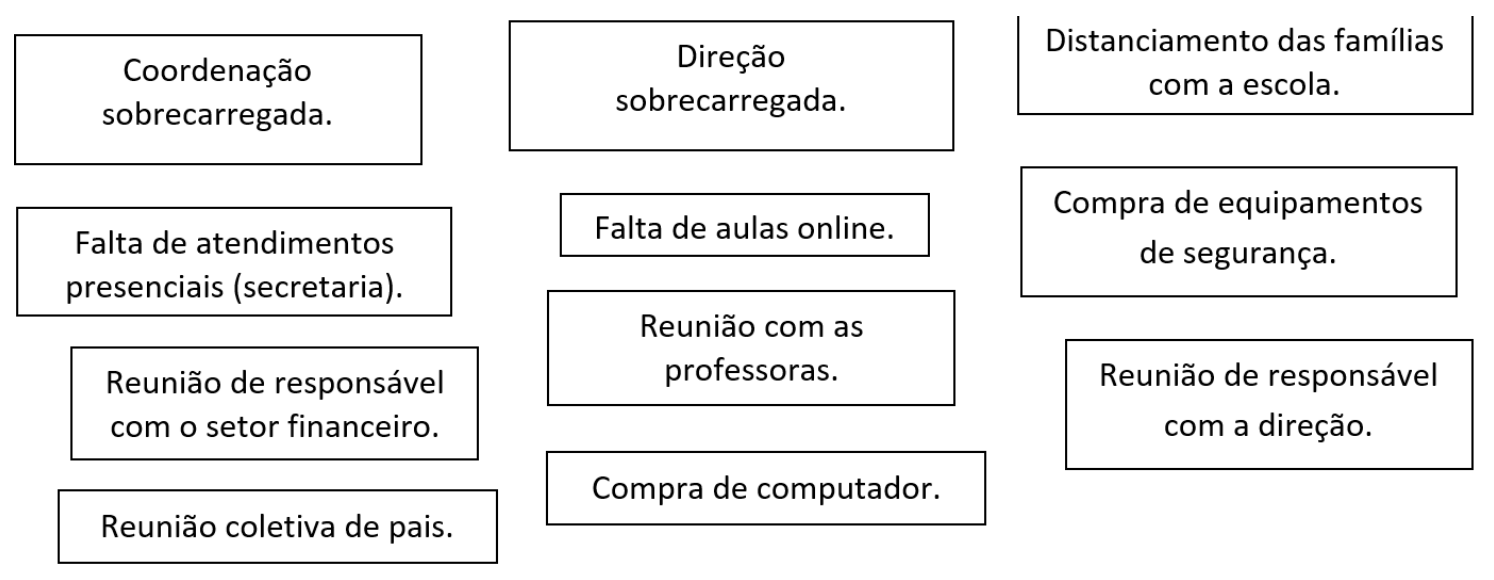

Fonte: Do autor, 2021.

Após o levantamento dos problemas atuais da escola foi utilizada a matriz GUT, tendo os valores dos parâmetros sido caracterizados na mesma reunião em que foi realizado o brainstorming. Na Tabela 2 é apresentada a matriz GUT no ciclo 2.

Tabela 2 - Matriz GUT no ciclo 2.

\begin{tabular}{|c|c|c|c|c|c|}
\hline Problemas & G & $\mathrm{U}$ & $T$ & Total & \\
\hline Distanciamento das famílias com a escola & 5 & 5 & 5 & 125 & \\
\hline Coordenação sobrecarregada & 4 & 5 & 5 & 100 & 을. $\overline{\bar{D}}$ \\
\hline Aulas on-line & 5 & 4 & 5 & 100 & $\begin{array}{lll}N & 0 \\
0 & 0 & 0 \\
0\end{array}$ \\
\hline Falta de atendimentos presenciais(secretaria) & 4 & 4 & 5 & 80 & \\
\hline Reunião de responsável com a direção & 4 & 4 & 5 & 80 & \\
\hline Compra de equipamentos de segurança & 3 & 2 & 4 & 24 & \\
\hline Reunião com as professoras & 2 & 2 & 3 & 12 & $\stackrel{\overparen{D}}{=}$ \\
\hline Reunião de responsável com o setor financeiro & 3 & 2 & 1 & 6 & \\
\hline
\end{tabular}


Direção sobrecarregada

Reunião coletiva de pais

Compra de computador

$\left.\begin{array}{llll}2 & 1 & 1 & 2 \\ 1 & 1 & 2 & 2 \\ 2 & 1 & 1 & 2\end{array}\right]$

Fonte: Do autor, 2021.

De acordo com a análise realizada, os problemas como falta de aproximação com as famílias, coordenação sobrecarregada, necessidade de atendimentos presenciais(secretaria) e reunião entre responsável do aluno com a direção da escola precisavam ser priorizados. Na reunião foi decidido analisar também o item aulas on-line, mesmo este não sendo considerado como item a ser priorizado, pois ele apresentava uma tendência forte a acontecer e a escola precisaria estar preparada.

\subsubsection{Observação}

$\mathrm{Na}$ etapa de observação foram analisadas as características dos problemas selecionados, conforme apresentado no Quadro 6.

Quadro 6 - Características dos problemas no ciclo 2.

\begin{tabular}{|c|c|}
\hline Problemas & Características específicas \\
\hline $\begin{array}{l}\text { Distanciamento das } \\
\text { famílias }\end{array}$ & $\begin{array}{l}\text { A escola tem em sua história o calor humano bastante presente e } \\
\text { com a falta de contato físico foi percebido um esfriamento na } \\
\text { relação entre a escola, a família e as crianças }\end{array}$ \\
\hline $\begin{array}{l}\text { Coordenação } \\
\text { sobrecarregada }\end{array}$ & $\begin{array}{l}\text { A elaboração das atividades impressas de diferentes turmas, } \\
\text { além de auxiliar no acompanhamento das notícias e estar junto } \\
\text { com a direção nas demandas de cada família deixaram a } \\
\text { coordenação sobrecarregada }\end{array}$ \\
\hline $\begin{array}{l}\text { Necessidade de } \\
\text { atendimentos } \\
\text { presenciais(secretaria) }\end{array}$ & $\begin{array}{l}\text { Os pais dos alunos da instituição de ensino em questão } \\
\text { começaram a questionar no próprio Instagram sobre os } \\
\text { atendimentos por telefone e/ou presenciais. A escola só estava } \\
\text { aberta às segundas-feiras de } 9 \mathrm{~h} \text { às } 11 \mathrm{~h} \text { e de } 13 \mathrm{~h} \text { às } 16 \mathrm{~h} \text {. }\end{array}$ \\
\hline $\begin{array}{l}\text { Reunião entre } \\
\text { responsável do aluno } \\
\text { com a direção da } \\
\text { escola }\end{array}$ & $\begin{array}{l}\text { Muitos pais solicitaram reuniões com a direção da escola para } \\
\text { esclarecer o que estava acontecendo e para saber se a escola já } \\
\text { tinha definido ações para minimizar os impactos }\end{array}$ \\
\hline Falta de aulas on-line & $\begin{array}{l}\text { Devido à continuidade da pandemia e à falta de preparo da } \\
\text { escola quantoàs tecnologias, iniciou-se a conversa da } \\
\text { possibilidade de aulas on-line,de modo a haver um preparo com } \\
\text { antecedência }\end{array}$ \\
\hline
\end{tabular}

Fonte: Do autor, 2021.

Levantadas as principais características dos problemas previamente selecionados, a próxima etapa da MASP foi analisar essas demandas. 


\subsubsection{Análise}

Para a etapa de análise foram elaborados três diagramas de Ishikawa por se tratarem de problemas que necessitavam de análises em mais de uma categoria e por terem a possibilidade de ter mais de uma causa raiz. Adicionalmente foram utilizadas duas vezes a técnica dos cinco porquês, uma vez que eram problemas gerais e que precisavam de afunilamento para se determinar uma causa raiz.

\subsection{Distanciamento das famílias}

O problema de distanciamento das famílias foi analisado utilizando o diagrama de Ishikawa, pois a direção e a coordenação acharam importante analisar as seis áreas que o diagrama possui, mesmo tendo encontrado causas em apenas duas áreas, conforme apresentado na Figura 9.

Figura 9 - Diagrama de Ishikawa sobre distanciamento das famílias.

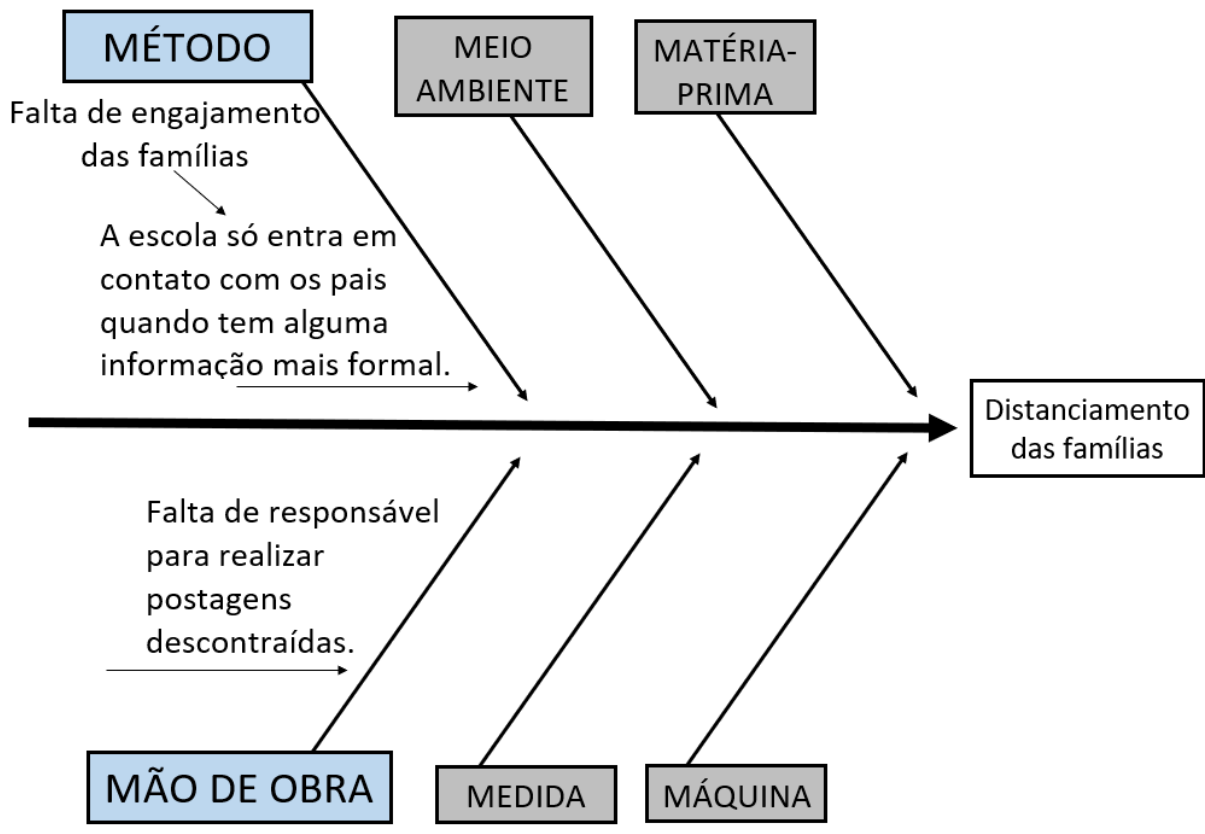

Fonte: Do autor, 2021.

As causas raízes do primeiro problema levantadas a partir da Figura 9 foram: falta de engajamento das famílias devido à formalidade das postagens da escola e falta de um responsável para realizar postagens mais descontraídas. 


\subsection{Coordenação sobrecarregada}

Para a análise da causa raiz da coordenação sobre carregada foi aplicada a técnica dos cinco porquês, como pode ser observado na Figura 10.

Figura 10 - Aplicação da técnica dos cinco porquês sobre a coordenação sobrecarregada.

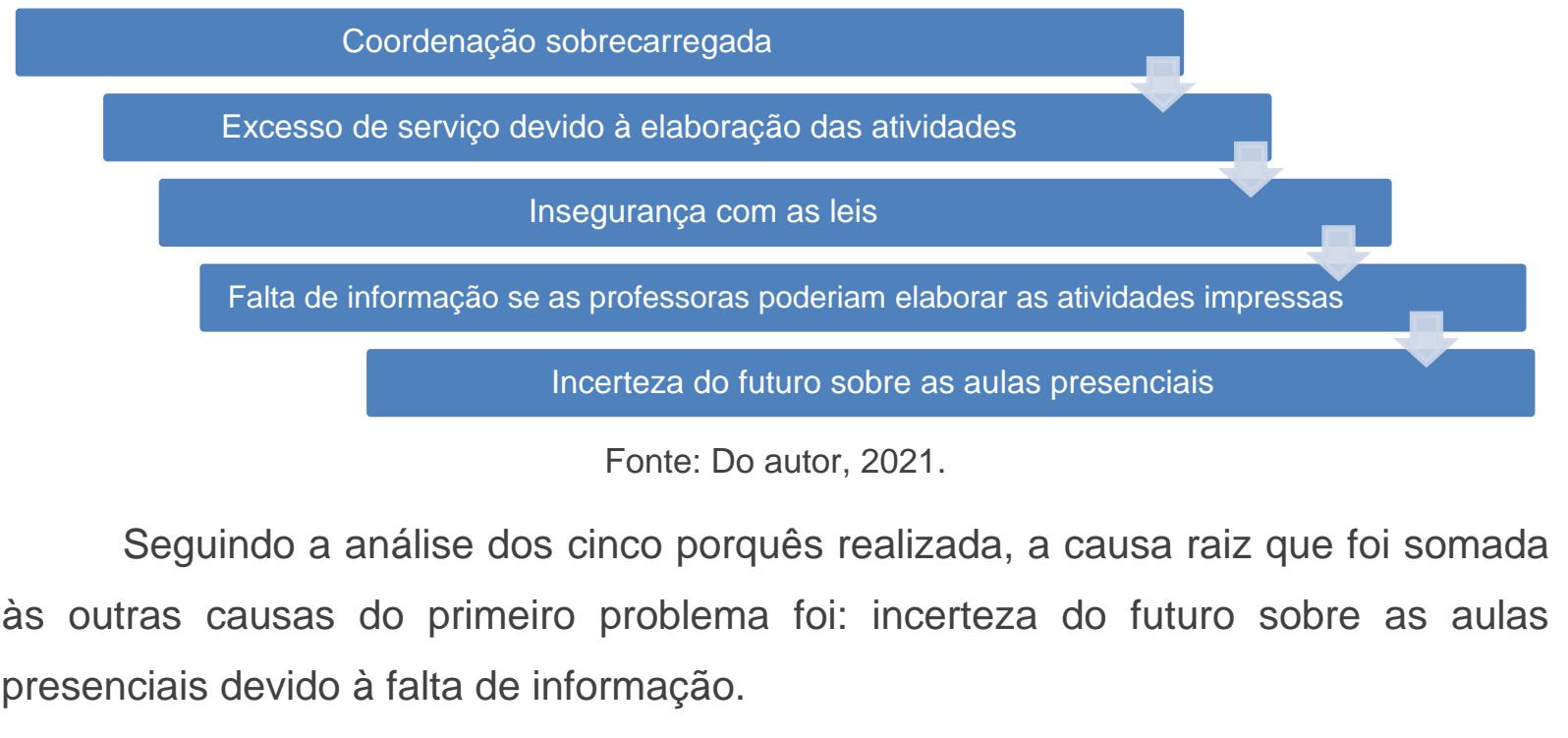

\subsection{Falta de atendimentos presenciais(secretaria)}

A análise dos cinco porquês foi utilizada para descobrir a causa raiz do problema de falta de atendimento presenciais, conforme apresentado na Figura 11.

Figura 11 - Aplicação da técnica dos cinco porquês sobre a falta de atendimentos presenciais (secretaria).

\footnotetext{
Falta de atendimentos presenciais (secretaria)
Distanciamento das familias
Perda da confiança dos pais com a escola por falta de informação
Falta de orientação para os pais ao receber informaçōes da escola pela rede social
Falta de realizar atendimentos no telefone e receber os pais na escola

Fonte: Do autor, 2021.

A necessidade de se realizarem atendimentos no telefone e receber os pais na escola foi a causa raiz do problema analisado.
} 
Para análise da demanda de reunião com os responsáveis pelos alunos com a direção da escola foi utilizado o diagrama de Ishikawa, pois a direção e coordenação também viram importância em analisar as seis áreas, conforme apresentado na Figura 12.

Figura 12 - Diagrama de Ishikawa sobre reunião entre responsável do aluno com a direção da escola.

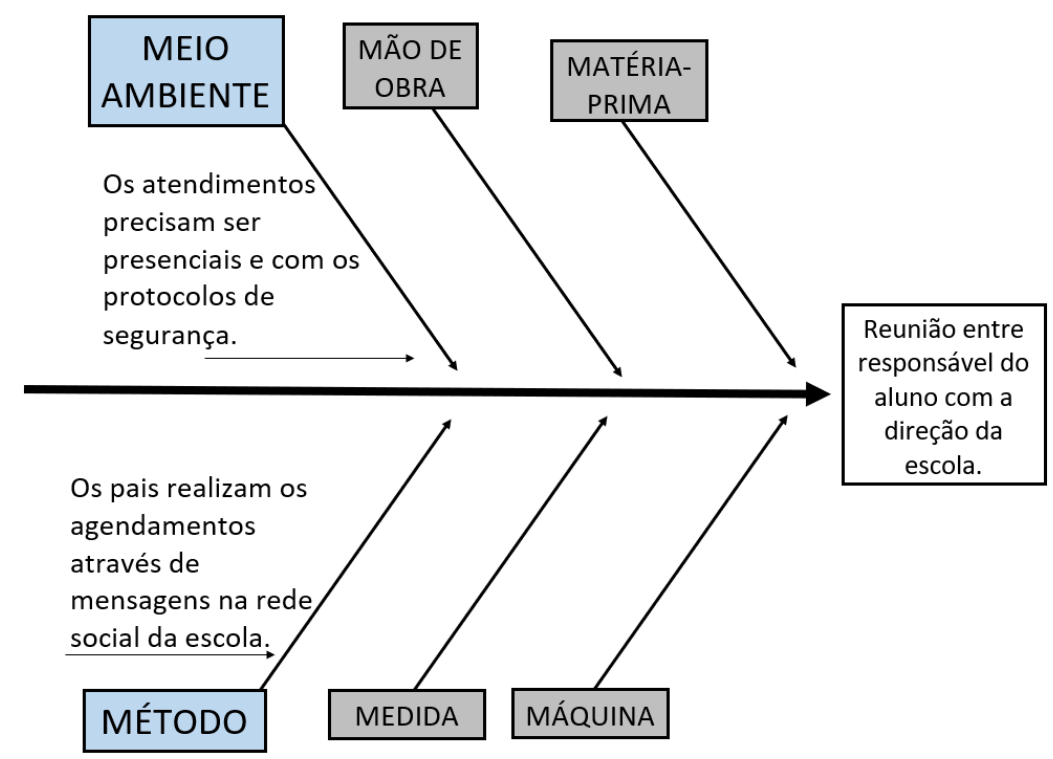

Fonte: Do autor, 2021.

As causas raizes do problema da reunião entre responsável pelo aluno com a direção da escola foram: atendimentos presenciais com protocolos de segurança e os agendamentos realizados pela rede social da escola.

\subsection{Falta de aulas on-line}

Para descobrir as causas raízes dos problemas gerados pela implementação das aulas on-line foi utilizado o diagrama de Ishikawa,conforme Figura 13. 
Figura 13 - Diagrama de Ishikawa sobre falta de aulas on-line.

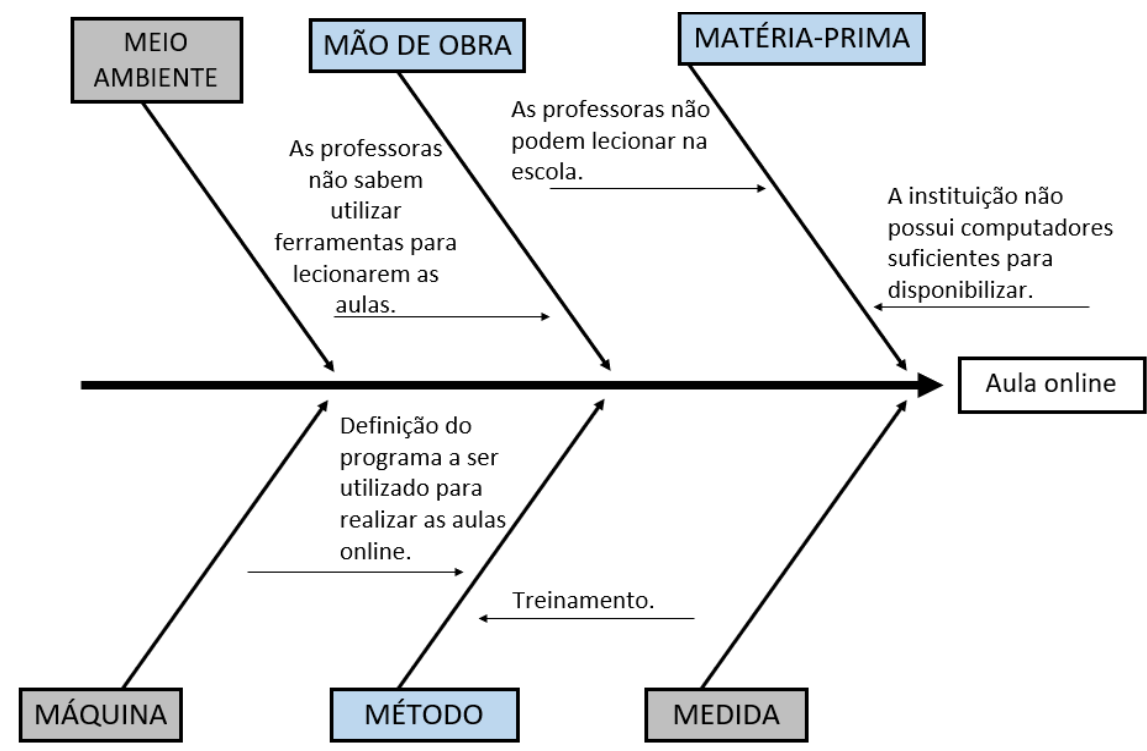

Fonte: Do autor, 2021.

Após analisar o último problema, mais causas raízes foram adicionadas as dos demais problemas para serem tratadas, como: i) falta de computadores; ii) escolha de programa a ser utilizado nas aulas; iii) professores não podiam lecionar na escola, mesmo sendo de maneira remota com seus alunos; e iv) falta de treinamento. Nesseponto, a etapa de análise foi concluída e a próxima etapa foi iniciada.

\subsubsection{Plano de ação}

A etapa plano de ação tem o objetivo de elaborar um plano a ser seguido para minimizar as causas raízes dos problemas em questão, que foram: i) falta de engajamento das famílias devido à formalidade das postagens da escola; ii) falta de responsável para realizar postagens descontraídas; iii) incerteza do futuro sobre as aulas presenciais devido à falta de informações legais; iv) a secretaria necessitava realizar atendimentos por telefone e receber os pais na escola; v) a direção necessitava atender presencialmente com protocolos de segurança; vi) os agendamentos das reuniões eram realizados apenas pela rede social da escola; vii) falta de computadores para os professores lecionarem aulas on-line; viii) escolha de programa a ser utilizado nas aulas; ix) professores não podiam lecionar na escola, mesmo sendo de maneira remota com seus alunos; e x) falta de treinamento dos professorespara as aulas on-line.

Para auxiliar na organização das etapas foi utilizada a técnica 5W1H em todas as demandas encontradas,conformepode ser observado no Quadro 7. 
Quadro 7 - 5W1H no ciclo 2.

\begin{tabular}{|c|c|c|c|c|c|c|}
\hline \multirow{2}{*}{ Solução / O que (What) } & \multicolumn{2}{|c|}{ Quando (When) } & \multirow{2}{*}{$\begin{array}{c}\text { Onde } \\
\text { (Where) }\end{array}$} & \multirow{2}{*}{ Quem (Who) } & \multirow{2}{*}{ Por que (Why) } & \multirow{2}{*}{ Como (How) } \\
\hline & Início & Fim & & & & \\
\hline $\begin{array}{l}\text { Falta de engajamento das } \\
\text { famílias devido à formalidade } \\
\text { das postagens da escola }\end{array}$ & 09/04 & $17 / 04$ & \multirow{2}{*}{$\begin{array}{l}\text { Na direção e } \\
\text { home office }\end{array}$} & \multirow{2}{*}{ Direção } & \multirow{2}{*}{$\begin{array}{l}\text { Quanto mais próxima a } \\
\text { relação entre as famílias } \\
\text { e a escola, mais apoio a } \\
\text { instituição possui. } \\
\text { Gentileza gera gentileza }\end{array}$} & $\begin{array}{l}\text { Postagens com dicas de atividades, brincadeiras, } \\
\text { experiências, dicas interessantes para auxiliar as famílias }\end{array}$ \\
\hline $\begin{array}{l}\text { Falta de responsável para } \\
\text { realizar postagens } \\
\text { descontraídas }\end{array}$ & 08/04 & $09 / 04$ & & & & $\begin{array}{l}\text { A princípio, a direção assume essa função para obter } \\
\text { segurança sobre o conteúdo transmitido na rede social }\end{array}$ \\
\hline $\begin{array}{l}\text { Incerteza do futuro sobre as } \\
\text { aulas presenciais devido à } \\
\text { falta de informações }\end{array}$ & 08/04 & $17 / 04$ & $\begin{array}{l}\text { Na direção e } \\
\text { home office }\end{array}$ & $\begin{array}{l}\text { Direção e } \\
\text { coordenação }\end{array}$ & $\begin{array}{l}\text { Quanto melhor a } \\
\text { qualidade das } \\
\text { informações, maior a } \\
\text { probabilidade de a } \\
\text { escola ser assertiva }\end{array}$ & $\begin{array}{c}\text { Aproveitar que a escola é sindicalizada com o Sindicato } \\
\text { das Escolas Particulares de Minas Gerais e manter o } \\
\text { contato para receber as informações, além de participar } \\
\text { dos cursos oferecidos por ele } \\
\text { Acompanhar ações de outras escolas particulares }\end{array}$ \\
\hline $\begin{array}{l}\text { A secretaria necessita realizar } \\
\text { atendimentos por telefone e } \\
\text { receber os pais na escola } \\
\text { Agendamentos das reuniões } \\
\text { eram realizados apenas pela } \\
\text { rede social da escola }\end{array}$ & $07 / 04$ & $17 / 04$ & Secretaria & Secretárias & $\begin{array}{l}\text { A escola precisa manter- } \\
\text { se em contato frequente } \\
\text { com a família de seus } \\
\text { alunos. }\end{array}$ & $\begin{array}{c}\text { Retorno das secretárias e dos atendimentos aos pais } \\
\text { presenciais apenas no portão da escola e por telefone de } \\
13 \mathrm{~h} \text { às } 16 \mathrm{~h}\end{array}$ \\
\hline $\begin{array}{l}\text { A direção necessita atender } \\
\text { presencialmente com } \\
\text { protocolos de segurança }\end{array}$ & $13 / 04$ & $17 / 04$ & $\begin{array}{l}\text { Sala de aula } \\
\text { do } 5^{\circ} \text { ano }\end{array}$ & Direção & $\begin{array}{l}\text { Ouvir as demandas dos } \\
\text { pais }\end{array}$ & $\begin{array}{l}\text { Atendimento realizado em uma sala isolada na escola de } \\
\text { forma agendada nas segundas-feiras }\end{array}$ \\
\hline $\begin{array}{c}\begin{array}{c}\text { Falta de computadores para } \\
\text { os professores lecionarem } \\
\text { aulas on-line }\end{array} \\
\text { Professores não podem } \\
\text { lecionar na escola, mesmo } \\
\text { sendo de maneira remota com } \\
\text { seus alunos }\end{array}$ & $10 / 04$ & $10 / 04$ & Home office & $\begin{array}{l}\text { Direção, } \\
\text { coordenação } \\
\text { e professores }\end{array}$ & $\begin{array}{l}\text { Possibilidade de a } \\
\text { escola fornecer aulas } \\
\text { on-line em um futuro } \\
\text { próximo }\end{array}$ & $\begin{array}{l}\text { Reunião on-line para buscar alternativas e soluções para } \\
\text { esse problema }\end{array}$ \\
\hline $\begin{array}{l}\text { Escolha de programa a ser } \\
\text { utilizado nas aulas }\end{array}$ & 09/04 & $12 / 04$ & Home office & Direção & $\begin{array}{l}\text { Escolher o programa } \\
\text { com maior } \\
\text { acessibilidade para os } \\
\text { professores, familiares e } \\
\text { secretaria } \\
\end{array}$ & $\begin{array}{c}\text { Pesquisa dos programas que fornecem o serviço, testes e } \\
\text { análise de acesso para os pais e professores }\end{array}$ \\
\hline $\begin{array}{c}\text { Falta de treinamento dos } \\
\text { professores para as aulas on- } \\
\text { line }\end{array}$ & $13 / 04$ & $14 / 04$ & Home office & $\begin{array}{l}\text { Direção e } \\
\text { professores }\end{array}$ & $\begin{array}{l}\text { Proporcionar a } \\
\text { viabilidade das aulas on- } \\
\text { line }\end{array}$ & $\begin{array}{l}\text { A escola irá fornecer um vídeo explicando como utilizar o } \\
\text { programa, fazer uma reunião para tirar dúvidas com todas } \\
\text { os professores e ficará disponível durante dois dias para } \\
\text { fazer testes e tirar todas as dúvidas que virem a surgir }\end{array}$ \\
\hline
\end{tabular}

Fonte: Do autor, 2021. 
Uma vez analisado e elaborado o plano de ação de acordo com cada demanda, o próximo passo foi a execução.

\subsubsection{Execução}

A etapa de execução foi o momento de colocar em prática o planejamento realizado de cada problema.

5.2.2.5.1 Falta de engajamento das famílias devido à formalidade das postagens da escola e falta de um responsável para realizar postagens descontraídas

A direção da escola não abriu mão de realizar as postagens na rede social da escola. Isso ocorreu pois havia uma preocupação quanto ao conteúdo das postagens da escola e também para garantir que a instituição continuasse com a imagem de cuidado, carinho e amor com os alunos e familiares. Sendo assim, a estratégia adotada foi praticar repostagens de outras contas de dicas de atividades, brincadeiras, experiências, dicas interessantes para auxiliar as famílias, oferecendo o crédito para as contas que criaram as postagens e utilizando hashtags para aumentar o alcance das postagens e adquirir novos seguidores.

5.2.2.5.2 Incerteza do futuro sobre as aulas presenciais devido à falta de informações

A direção ficou responsável por manter contato com o Sindicato das Escolas Particulares de Minas Gerais (SINEP/MG), participar dos cursos oferecidos pelo sindicato e tentar estabelecer contato com a Secretaria Municipal de Educação de Minas Gerais e com a Secretaria Estadual de Educação de Minas Gerais. A coordenação ficou responsável por pesquisar ação de outras escolas particulares para analisar possibilidades futuras.

5.2.2.5.3 Agendamentos das reuniões eram realizados apenas pela rede social da escola e a secretaria necessita realizar atendimentos pelo telefone e receber os pais na escola

Para minimizar os problemas de agendamentos e atendimento, a escola ampliou os dias de atendimentos da secretaria de segunda-feira à sexta-feira nos 
seguintes horários: segunda-feira de $9 \mathrm{~h}$ às $11 \mathrm{~h}$ e de $13 \mathrm{~h}$ às $16 \mathrm{~h}$ e de terça-feira à sexta-feira de 12h30min às 16h. Dessa forma, os pais e/ou responsáveis tiveram mais acessibilidade para atendimentos na instituição.

5.2.2.5.4 A direção necessita de atender presencialmente com protocolos de segurança

A fim de atender melhor as famílias, a direção da escola abriu a agenda de atendimentos uma vez por semana alternando entre os turnos da manhã e da tarde e variando os dias de acordo com a demanda.

5.2.2.5.5 Falta de computadores para os professores lecionarem aulas on-line e impedimento para os professores lecionarem mesmo de maneira remota na escola

Como a direção e a coordenação não encontraram soluções para a falta de computadores para os professores lecionarem aulas on-line e para o impedimento de as aulas serem remotas serem ministradas da escola foi marcada uma reunião on-line com os professores para explicar a situação e ouvir o que os eles tinham a dizer. Nessa reunião, os professores se propuseram a usar os computadores pessoais para fazerem um teste com aulas on-line de uma hora de duração já nos dias 15, 16 e 17 de abril.

Vale ressaltar que os objetivos propostos em reunião por todos envolvidos foram de realizar o teste de formato de aula on-line no contexto vivido, manter o vínculo com o aluno mesmo em tempos de pandemia e sanar dúvidas pedagógicas oriundas da realização das atividades entregues.

\subsection{Escolha do programa a ser utilizado nas aulas}

A seleção do programa foi feita levando em consideração que um dos integrantes da direção sabia utilizar uma determinada plataforma, que, além de ser de fácil acesso, oferecia videochamadas de até 40 minutos em sua versão gratuita. Essa escolha visou otimizar o tempo para aprendizagem das ferramentas e treinamento dos professores. Após a aprovação da direção e coordenação, a direção ficou responsável por fornecer o treinamento e elaborar o manual de uso para os pais e/ou responsáveis até o dia 14 de abril. A direção e secretaria ficaram 
também responsáveis por entrar em contato com a família dos alunos para solicitar o e-mail e enviar o link de acesso.

5.2.2.5.7 Falta de treinamento dos professores para as aulas on-line

Devido ao curto espaço de tempo foi realizada apenas uma reunião para apresentar a ferramenta para os professores. Assim, um dos responsáveis da direção assumiu a responsabilidade de ser o anfitrião de todas as salas e auxiliar os docentes nos três primeiros dias. Logo, as aulas foram marcadas de $7 \mathrm{~h}$ às $11 \mathrm{~h}$ (quatro turmas com uma hora de duração cada aula) e de 13h às 15h (duas turmas com uma hora de duração cada aula).

\subsubsection{Verificação}

$\mathrm{Na}$ etapa de verificação, os resultados obtidos foram comparados aos objetivos traçados.

5.2.2.6.1 Falta de engajamento das famílias devido à formalidade das postagens da escola e falta de responsável para realizar postagens descontraídas

Uma vez executado o plano de ação, houve um aumento no número de seguidores de 150 para 453, bem como um aumento no número de interações em cada publicação da escola.

5.2.2.6.2 Incerteza do futuro sobre as aulas presenciais devido à falta de informações

A verificação desse item se deu por meio do acompanhamento das ações de outras escolas situadas em Belo Horizonte, pois, caso outras instituições adotassem diferentes estratégias, a escola estaria informada e entraria em contato com o sindicato para perguntar sobre a legalidade dessas ações. Como o intuito da instituição era apenas ver as possibilidades, não foi divulgado o nome de outras instituições para o sindicato. 
5.2.2.6.3 Agendamentos das reuniões eram realizados apenas pela rede social da escola e a secretaria necessitava realizar atendimentos por telefone e receber os pais na escola

As reuniões passaram a ser agendadas em sua maioria por telefone e a procura dos pais por aproximação com a escola aumentou. A escola passou a atender em torno de 30 pais diariamente por telefone ou presencialmente.

5.2.2.6.4 A direção necessita atender presencialmente com protocolos de segurança

A escola acompanhou as informações de segurança da OMS e os protocolos de segurança elaborados pelos órgãos competentes da região na qual a escola está situada.

5.2.2.6.5 Falta de computadores para os professores lecionarem aulas on-line, impedimento para os professores lecionarem mesmo de maneira remota na escola, escolha de programa a ser utilizado nas aulas e falta de treinamento dos professores para as aulas on-line

A verificação foi realizada através dos feedbacks dos pais e com a lista de presença nas aulas on-line, além de a direção e a coordenação estarem em contato com os professores diariamente. Nas aulas-teste, apenas uma professora perdeu a conexão, mas a direção estava de prontidão para continuar a aula seguindo o planejamento enviado previamente até que a professora conseguisse retomar a aula.

\subsubsection{Padronização}

Com o aumento do engajamento na página da escola na rede social foi estabelecido realizar três postagens diárias, porém, quando a escola fizesse uma publicação com informação importante, a regra seria voltar a postar novamente apenas com o prazo de 24 horas.

A respeito da incerteza e da falta de informação, a escola se organizou para realizar uma reunião semanal com a direção e coordenação e quinzenalmente com os professores para decidirem juntos as ações da escola. 
Em relação às reuniões de pais com a direção foi padronizado um atendimento semanal,sendo as marcações realizadas no decorrer da semana.

Quantoàsaulas on-line era necessário $100 \%$ de adesão dos alunos para validação das aulas perante o governo, porém as porcentagens de presenças variaram de $57 \%$ a $78 \%$, de modo quenão puderam ser validadas.

\subsubsection{Conclusão}

O aumento do número de seguidores e do engajamento das famílias foi interpretado como ponto positivo, de modo que a ação das postagens foi considerada válida. Adicionalmente, as ações para manter a instituição informada sobre as leis atuais para o ambiente incerto também foi considerada positiva, pois a escola conseguiu ter mais confiança em suas ações. Ademais, as reuniões proporcionaram melhor interação com a equipe.

A impressão que os pais forneceram para a escola foi que eles tiveram mais liberdade e aproximação para falarem das demandas individuais com a direção e com a secretaria. A escola tornou-se mais acessível na percepção deles. Já a ação de ofertar aulas on-line foi muito elogiada e tida como válida, porém não era algo autorizado por lei, já que nem todos os alunos participaram.

Em resumo, a MASP proporcionou maior segurança e clareza para a caminhada incerta até o momento. Porém, a escola apresentou novas demandas, de modo que uma nova MASP foi iniciada no dia 20 de abril.

\subsubsection{MASP ciclo 3}

No dia 20 de abril de 2020 foi realizada uma nova reunião entre coordenação e a direção para dar início a uma nova MASP de modo a sanar as demandas desse período.

\subsubsection{Identificação do problema}

Para auxiliar na identificação dos problemas foi realizada a técnica de brainstorming na reunião entre a direção e a coordenação da empresa, tendo sido levantados os problemas, conforme apresentado na Figura 14. 
Figura 14 - Brainstorming no ciclo 3.
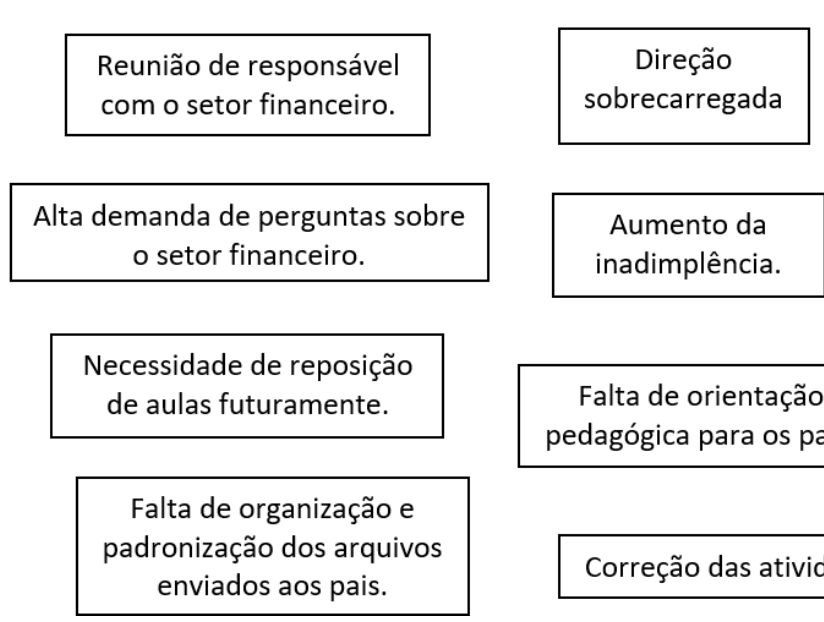
Sistema de avaliação diagnóstica.

com o setor financeiro.

Alta demanda de perguntas sobre setor financeiro.

Necessidade de reposição de aulas futuramente.

Falta de organização e enviados aos pais.

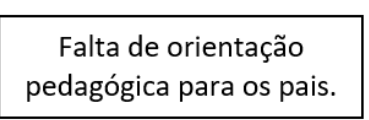

Reunião coletiva de pais.

Falta de aulas.
Correção das atividades remotas.

Fonte: Do autor, 2021.

Após levantamento dos problemas da escola nesse período foi utilizada a matriz GUT, tendo os valores dos parâmetros sido caracterizados na mesma reunião em que foi realizado o brainstorming. Na Tabela 3 é apresentada a matriz GUT no ciclo 3.

Tabela 3 - Matriz GUT no ciclo 3.

\begin{tabular}{|c|c|c|c|c|c|}
\hline Problemas & G & $\mathbf{U}$ & $\mathrm{T}$ & Total & \\
\hline Falta às aulas & 5 & 5 & 5 & 125 & \\
\hline Alta demanda de perguntas sobre o setor financeiro & 4 & 5 & 5 & 100 & స. \\
\hline Falta de organização e padronização dos arquivos enviados aos pais & 5 & 4 & 5 & 100 & \\
\hline Presente do dia das mães & 4 & 3 & 5 & 60 & \\
\hline Necessidade de reposição de aulas futuramente & 3 & 2 & 5 & 30 & \\
\hline Aumento da inadimplência & 3 & 2 & 2 & 12 & $\circ \overrightarrow{0}$ \\
\hline Correção das atividades remotas & 2 & 2 & 2 & 8 & \\
\hline Reunião coletiva de pais & 1 & 2 & 2 & 4 & \\
\hline Direção sobrecarregada & 3 & 1 & 1 & 3 & \\
\hline Sistema de avaliação diagnóstica & 1 & 1 & 2 & 2 & \\
\hline Compra de equipamentos de segurança & 1 & 1 & 1 & 1 & \\
\hline
\end{tabular}

Fonte: Do autor, 2021.

De acordo com a análise realizada, os problemas como falta às aulas, alta demanda de perguntas sobre o setor financeiro, falta de organização e padronização dos arquivos enviados aos pais e presente referente ao dia das mães precisavam ser priorizados.

\subsubsection{Observação}

$\mathrm{Na}$ etapa observação foram analisadas as características dos problemas selecionados, conforme apresentado no Quadro 8. 
Quadro 8 - Características dos problemas no ciclo 3.

\begin{tabular}{|c|c|}
\hline Problemas & Características específicas \\
\hline Falta às aulas & $\begin{array}{l}\text { As aulas on-line em tempo real não obtiveram } 100 \% \text { de participação } \\
\text { dos alunos, logo, a escola precisa criar outra alternativa para continuar } \\
\text { ensinando os alunos para que eles tenham habilidade e conhecimento } \\
\text { para realizar as atividades remotas e atividades dos livros que estão } \\
\text { sendo enviadas para realizarem em casa }\end{array}$ \\
\hline
\end{tabular}

Como a escola estava impedida de fornecer os serviços preestabelecidos no contrato anual assinado pela instituição mantenedora e pelos responsáveis legais pelos alunos, os

Alta demanda de perguntas sobre 0 setor financeiro responsáveis começaram a questionar a necessidade de pagamento das mensalidades, o que é um risco para a sobrevivência da escola, pois sua única receita advém das mensalidades. Em contrapartida, o sindicato que representa os professores na região não permitiu a redução de carga horária, pois eles teriam que repor todas as aulas futuramente

Falta de organização e padronização dos arquivos enviados aos pais

Presente referente ao dia das mães
A cada semana, a direção da escola é responsável por receber as atividades de cada sala elaboradas pelo professor e avaliadas pela coordenação para impressão e envio aos responsáveis. Porém, as atividades enviadas precisam ser organizadas no computador da direção e enviadas para a secretaria para auxílio no envio. A escola precisa otimizar esse processo para facilitar para todos envolvidos

Todos os anos, a escola oferece lembrancinhas em datas comemorativas elaboradas pela própria direção sem custo adicional. Com a chegada do dia das mães, é necessário planejar para que a essência dos projetos desenvolvidos não seja perdida e para que a escola possa demonstrar a todos que continua funcionando normalmente

Fonte: Do autor, 2021.

Levantadas as principais características dos problemas previamente selecionados, a próxima etapa da MASP foi analisar essas demandas.

\subsubsection{Análise}

Para a análise foi elaborado um diagrama de Ishikawa e a técnica dos cinco porquês foi utilizada duas vezes.

\subsection{Falta às aulas}

O problema de falta às aulas foi analisado utilizando o diagrama de Ishikawa, conforme apresentado na Figura 15. 
Figura 15 - Diagrama de Ishikawa sobre falta às aulas.

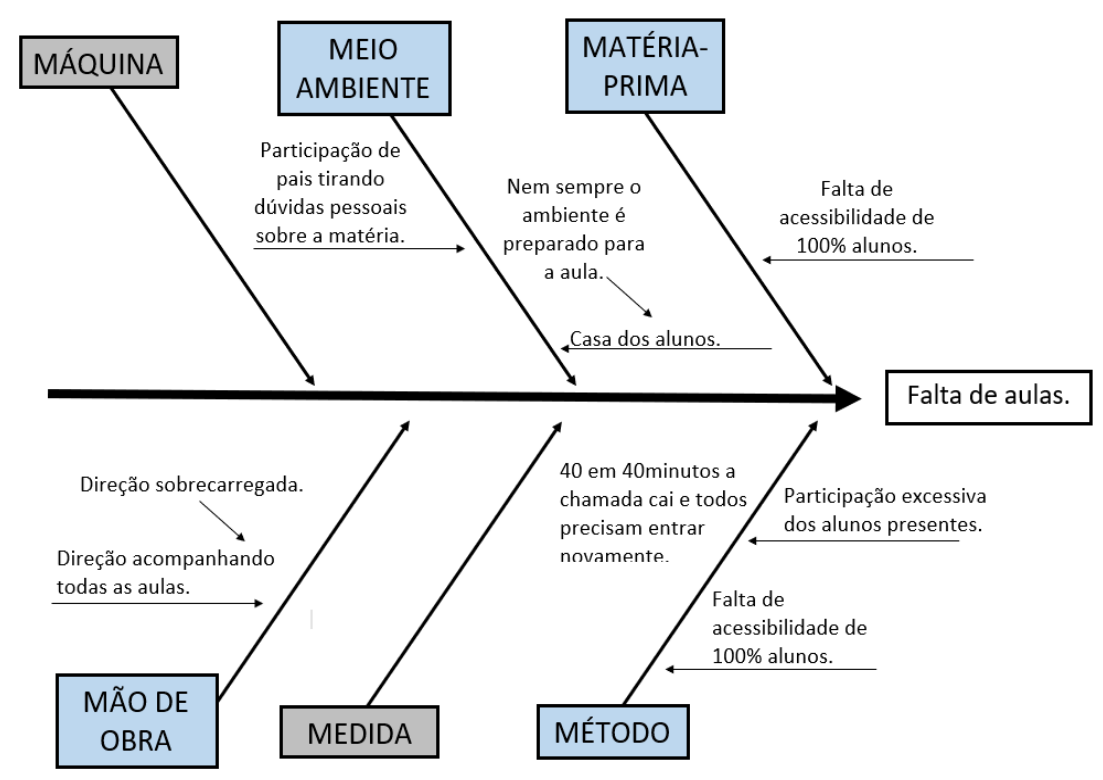

Fonte: Do autor, 2021.

As causas raízes do primeiro problema levantadas a partir da Figura 15 foram: participação de pais tirando dúvidas pessoais sobre a matéria, nem sempre o ambiente estava preparado para a aula, falta de acessibilidade de $100 \%$ alunos, direção sobrecarregada, de 40 em 40 minutos a chamada caía e todos precisam entrar novamente e participação excessiva dos alunos presentes. Diante da quantidade de dificuldades apontadas foi observado que a escola precisava buscar um novo meio para fornecer as aulas on-line.

5.2.3.3.2 Alta demanda de perguntas sobre o setor financeiro

Para a análise da causa raiz da alta demanda de perguntas sobre o setor financeiro foi aplicada a técnica dos cinco porquês, conforme apresentado na Figura 16. 
Figura 16 - Aplicação da técnica dos cinco porquês para a alta demanda de perguntas sobre o setor financeiro.

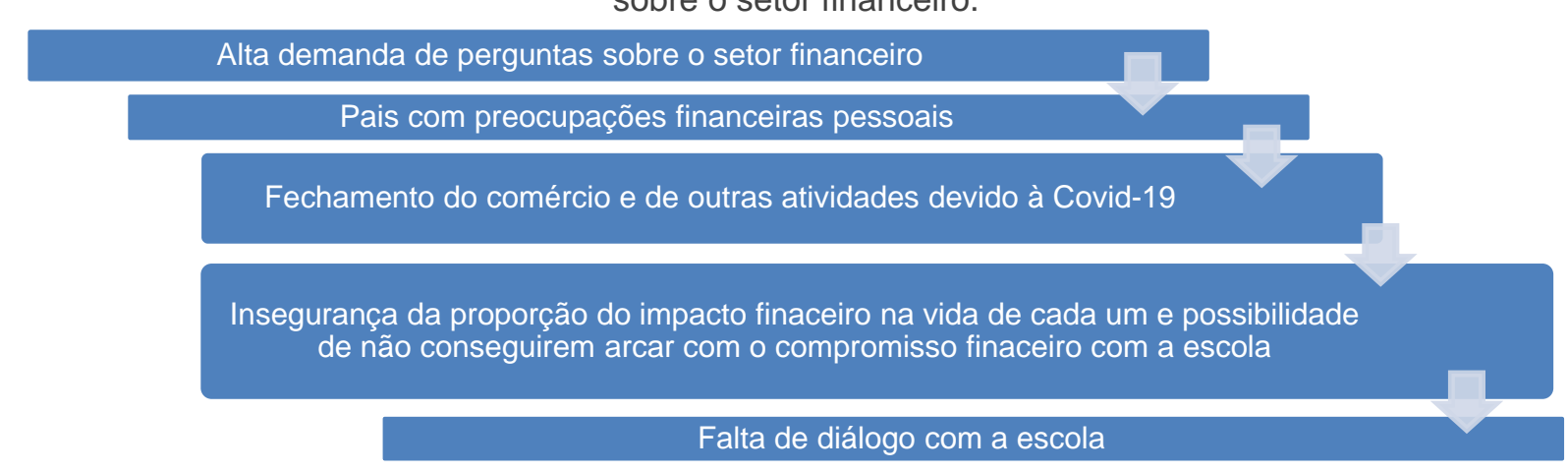

Fonte: Do autor, 2021.

Seguindo a análise dos cincoporquês realizada, a causa raiz que foisomada àsoutras causas do primeiro problema foi a falta de diálogo com a escola.

5.2.3.3.3 Falta de organização e padronização dos arquivos enviados aos pais

Foi utilizada na análise da demanda de falta de organização e padronização dos arquivos enviados aos pais a técnica dos cinco porquês, conforme Figura 17.

Figura 17 - Aplicação da técnica dos cinco porquês sobre a falta de organização e padronização dos arquivos enviados aos pais

Falta de organização e padronização dos arquivos enviados aos pais

Recebimento dos arquivos de diferentes professores e com formatos com necessidade de alterações

Alta demanda de tempo na busca de arquivos quando os responsáveis solicitam posteriomente a data

Arquivos em computadores diferentes

Alta possibilidade de perder arquivos com as atividades

Fonte: Do autor, 2021.

A alta possibilidade de perder arquivos com as atividades foi mais uma causa raiz que foi somada àsoutras desseciclo MASP.

5.2.3.3.4 Presente referente ao dia das mães

Para analisar as cauzas raízes dessa demanda foi utilizado o método de Ishikawa, conforme apresentado na Figura 18. 
Figura 18 - Diagrama de Ishikawa sobre presente do dia das mães.

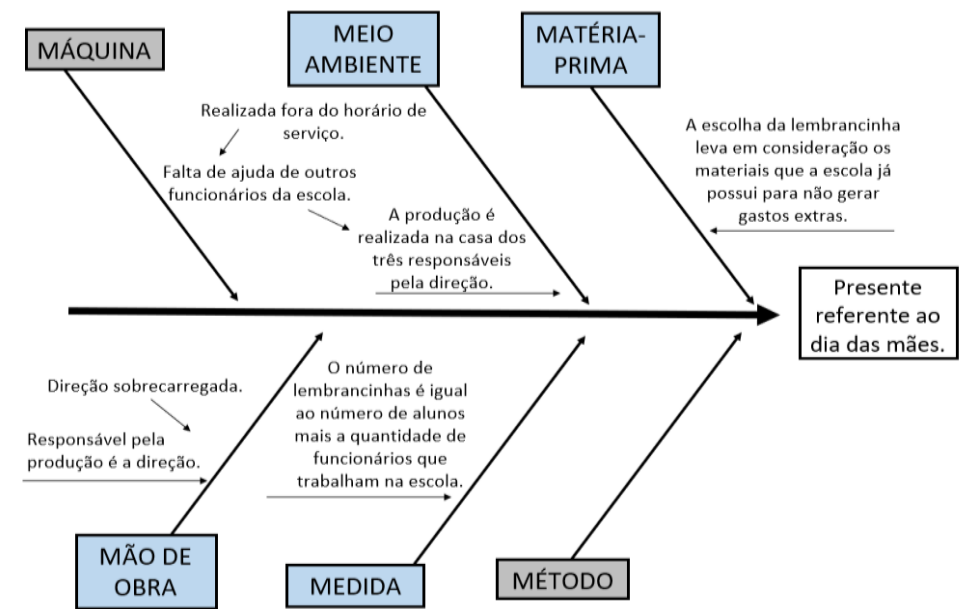

Fonte: Do autor, 2021.

Diante do diagrama de Ishikawa utilizado foi possível observar que a principal dificuldade nas causas raízes foi a sobrecarga da direção para elaborar a lembrança do dia das mães. Esse problema foiadicionado àbusca de um novo meio para fornecer as aulas on-line, falta de diálogo com a escola e alta possibilidade de perder arquivos com as atividades. Frente a essas demandas foi elaborado o plano de ação.

\subsubsection{Plano de ação}

A etapa plano de ação tem o objetivo de elaborar um plano a ser seguido para minimizar as causas raízes dos problemas em questão, que foram: i) busca de um novo meio para fornecer as aulas on-line; ii) falta de diálogo com a escola em relação ao financeiro; iii) alta possibilidade de perder arquivos com as atividades; e iv) sobrecarga da direção para elaborar a lembrança do dia das mães.

Para auxiliar na organização das etapas foi utilizada a técnica $5 \mathrm{~W} 1 \mathrm{H}$ em todas as demandas encontradas, conforme apresentado no Quadro 7.

Quadro $9-5 \mathrm{~W} 1 \mathrm{H}$ do ciclo 3.

\begin{tabular}{|c|c|c|c|c|c|c|}
\hline \multirow{2}{*}{$\begin{array}{c}\text { Solução / } \\
\text { O que } \\
\text { (What) }\end{array}$} & \multicolumn{2}{|c|}{$\begin{array}{l}\text { Quando } \\
\text { (When) }\end{array}$} & \multirow{2}{*}{$\begin{array}{c}\text { Onde } \\
\text { (Where) }\end{array}$} & \multirow{2}{*}{$\begin{array}{l}\text { Quem } \\
\text { (Who) }\end{array}$} & \multirow[t]{2}{*}{ Por que (Why) } & \multirow[t]{2}{*}{ Como (How) } \\
\hline & Início & Fim & & & & \\
\hline $\begin{array}{l}\text { Busca de } \\
\text { um novo } \\
\text { meio para } \\
\text { fornecer as } \\
\text { aulas on- } \\
\text { line }\end{array}$ & $20 / 04$ & $16 / 05$ & $\begin{array}{c}\text { Home } \\
\text { office }\end{array}$ & $\begin{array}{c}\text { Direção, } \\
\text { coordenaçã } \\
\text { o e } \\
\text { professores }\end{array}$ & $\begin{array}{c}\text { A escola precisa } \\
\text { chegar até seus } \\
\text { alunos para ensinar e } \\
\text { passar atividades. Ou } \\
\text { seja, a escola precisa } \\
\text { oferecer } \\
\text { desenvolvimento e } \\
\text { conhecimento a eles }\end{array}$ & $\begin{array}{c}\text { Decidiu-se por fornecer } \\
\text { aulas gravadas e } \\
\text { enviadas por link } \\
\text { utilizando a nuvem do e- } \\
\text { mail da escola }\end{array}$ \\
\hline
\end{tabular}




\begin{tabular}{|c|c|c|c|c|c|c|}
\hline $\begin{array}{l}\text { Falta de } \\
\text { diálogo com } \\
\text { a escola em } \\
\text { relação ao } \\
\text { financeiro }\end{array}$ & $20 / 04$ & $27 / 04$ & $\begin{array}{l}\text { Sala de } \\
\text { aula do } \\
5^{\circ} \text { ano }\end{array}$ & $\begin{array}{l}\text { Direção - } \\
\text { setor } \\
\text { financeiro }\end{array}$ & $\begin{array}{l}\text { Pressão dos pais } \\
\text { quanto ao } \\
\text { posicionamento da } \\
\text { escola }\end{array}$ & $\begin{array}{l}\text { Reuniões semanais com o } \\
\text { responsável do setor } \\
\text { financeiro, sendo } \\
\text { preferencialmente às } \\
\text { segundas-feiras, pois é o } \\
\text { momento que muitos pais } \\
\text { buscam as atividades na } \\
\text { escola }\end{array}$ \\
\hline $\begin{array}{l}\text { Alta } \\
\text { possibilidad } \\
\text { e de perder } \\
\text { arquivos } \\
\text { com as } \\
\text { atividades }\end{array}$ & $22 / 04$ & $29 / 04$ & $\begin{array}{l}\text { Home } \\
\text { office }\end{array}$ & Direção & $\begin{array}{l}\text { Caso ocorra a perda } \\
\text { do arquivo, a escola } \\
\text { precisará refazer as } \\
\text { atividades ou } \\
\text { digitalizar as } \\
\text { atividades que estão } \\
\text { impressas }\end{array}$ & $\begin{array}{l}\text { Concentrar o recebimento } \\
\text { em apenas um } \\
\text { computador; transformar } \\
\text { todos os arquivos no } \\
\text { formato PDF; criar um link } \\
\text { para salvar e } \\
\text { disponibilizar todas as } \\
\text { atividades separadamente } \\
\text { por idade }\end{array}$ \\
\hline $\begin{array}{l}\text { Sobrecarga } \\
\text { da direção } \\
\text { para } \\
\text { elaborar a } \\
\text { lembrança } \\
\text { do dia das } \\
\text { mães }\end{array}$ & $21 / 04$ & $08 / 05$ & $\begin{array}{c}\text { Home } \\
\text { office }\end{array}$ & Direção & $\begin{array}{l}\text { A direção tem outras } \\
\text { funções, logo, precisa } \\
\text { de um processo mais } \\
\text { fácil para ter tempo } \\
\text { hábil para realizar } \\
\text { outras tarefas }\end{array}$ & $\begin{array}{l}\text { Seleção do modelo da } \\
\text { lembrancinha e } \\
\text { determinação das } \\
\text { pessoas que irão } \\
\text { desenvolvê-las }\end{array}$ \\
\hline
\end{tabular}

Fonte: Do autor, 2021.

Uma vez analisado e elaborado o plano de ação de acordo com cada demanda, o próximo passo foi a execução.

\subsubsection{Execução}

A etapa de execução foi o momento de colocar em prática o planejamento realizado de cada problema.

\subsection{Busca de um novo meio para fornecer as aulas on-line}

O processo para envio das videoaulas foi de acordo com o fluxograma representado na Figura 19.

Figura 19 - Fluxograma para a busca de um novo meio para fornecer as aulas on-line.

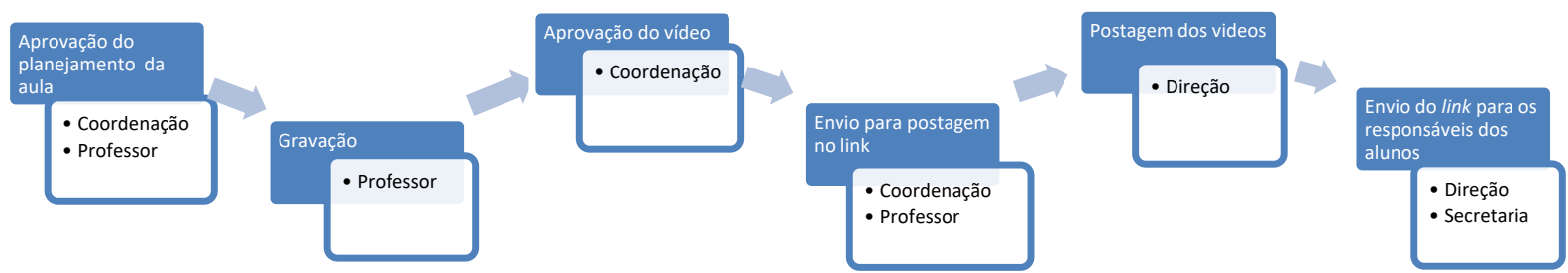

Fonte: Do autor, 2021.

O processo para envio das videoaulas foi realizado primeiramente com a aprovação do planejamento da aula pela coordenação, em seguida, os professores gravaram os vídeos, que foram enviados novamente para aprovação da coordenação. Após essas etapas, o vídeo foi enviado para a direção para que o link 
de acesso fosse gerado e enviado aos responsáveis. A secretaria auxiliou nessa etapa. Em adição, no dia 8 de maio de 2020, a escola forneceu um plantão pedagógico para tirar dúvidas on-line com os professores utilizando o mesmo aplicativo e com o acompanhamento da direção.

\subsection{Falta de diálogo com a escola em relação ao financeiro}

Para aumentar o diálogo com os responsáveis dos alunos da escola, a secretaria passou a agendar outras reuniões com o setor da direção responsável pela parte financeira. Assim, a direção teria acesso direto às demandas e poderia planejar o que faria para auxiliá-los.

\subsection{Alta possibilidade de perder arquivos com as atividades}

Foi elaborado um fluxograma para apresentar o processo necessário para reduzir os problemas relacionados à alta possibilidade de perder arquivos com atividades. O fluxograma elaborado pode ser observado na Figura 20.

Figura 20 - Fluxograma sobre alta possibilidade de perder arquivos com as atividades.

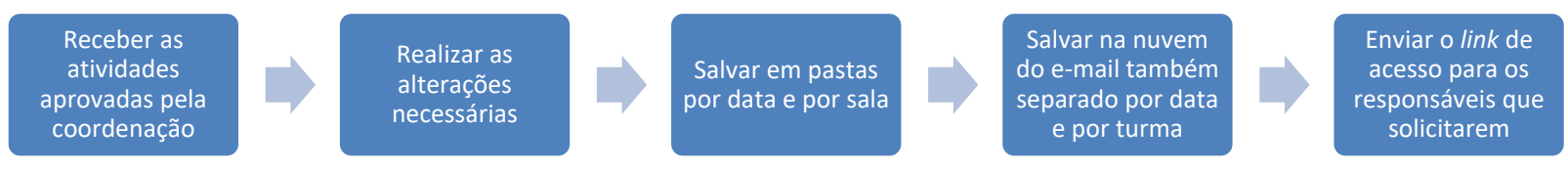

Fonte: Do autor, 2021.

Para evitar a perda das atividades, a direção passou a receber as aprovadas pela coordenação, realizar as alterações necessárias, salvar em pastas por data e por sala, salvar na nuvem do e-mail também separado por data e por turma e enviar o link de acesso para os responsáveis que solicitassem.

\subsection{Sobrecarga da direção para elaborar a lembrança do dia das mães}

Para facilitar para a direção, a elaboração da lembrança do dia das mães foi redistribuída entre as pessoas envolvidas de acordo com a carga de serviço e a habilidade. Assim, após a escolha da lembrancinha a ser elaborada, uma das pessoas ficou com a responsabilidade dessa demanda e as demais ficaram apenas 
como apoio. Ademais, a direção contratou uma pessoa externa para auxiliar no processo.

\subsubsection{Verificação}

A verificação dos problemas dessa etapa foi realizada conforme o Quadro 10.

Quadro 10 - Relação de problema com a checagem.

\begin{tabular}{|c|c|}
\hline Problema & Verificação \\
\hline $\begin{array}{l}\text { Busca de um novo meio para fornecer as } \\
\text { aulas on-line }\end{array}$ & $\begin{array}{l}\text { E-mail enviado a todos os pais com o link } \\
\text { das videoaulas }\end{array}$ \\
\hline $\begin{array}{l}\text { Falta de diálogo com a escola em relação } \\
\text { ao financeiro }\end{array}$ & $\begin{array}{l}\text { Atas de reuniões com os responsáveis } \\
\text { financeiros dos alunos }\end{array}$ \\
\hline Alta possibilidade de perder arquivos com & $\begin{array}{l}\text { Arquivos de atividades bem organizado nos } \\
\text { dois computadores }\end{array}$ \\
\hline & Upload das atividades para o link \\
\hline $\begin{array}{l}\text { Sobrecarga da direção para elaborar a } \\
\text { lembrança do dia das mães }\end{array}$ & $\begin{array}{l}\text { Número de lembrancinhas finalizadas a cada } \\
\text { semana }\end{array}$ \\
\hline
\end{tabular}

Fonte: Do autor, 2021.

Conforme o Quadro 10, o controle foi realizado por meio de: i) e-mail enviado a todos os pais com o link das videoaulas; ii) atas de reuniões com os responsáveis financeiros dos alunos; iii) arquivos de atividades bem organizado nos dois computadores; iv) upload das atividades para o link; e v) número de lembrancinhas finalizadas a cada semana.

\subsubsection{Padronização}

A padronização das videoaulas foi realizada também em reunião, tendo sido definido que cada professor do Ensino Fundamental ficaria responsável por elaborar seis vídeos por semana e que os professores da Educação Infantil ficariam com o compromisso de enviar dois vídeos por semana. Já as reuniões financeiras seriam realizadas com agendamento e nas segundas-feiras quando os responsáveis fossem buscar as atividades impressas dos alunos.

O controle das atividades foirealizado através do link e nos dois computadores e a produção das lembrancinhas foiacompanhada semanalmente. 


\subsubsection{Conclusão}

A busca por um novo modelo de aula foi interessante e desafiadora, tendo possibilitado uma nova modalidade de aula aos alunos. Com isso, a escola conseguiu atender o pré-requisito de $100 \%$ dos alunos terem acesso, cumprindo, assim, as orientações da Secretaria de Educação.

Para a falta de diálogo com a escola em relação ao financeiro, a ação de marcar reuniões foi produtiva quanto à aproximação com os pais. Em contrapartida, os responsáveis financeiros pelos alunos aumentaram as pressões para redução das mensalidades, de modo que a escola precisaria planejar suas reduções de despesas para fornecer uma redução consciente e responsável.

O controle e organização das atividades enviadas semanalmente, por sua vez, foi considerado de sucesso. As pastas ficaram organizadas e as atividades ficaram disponíveis para todos os responsáveis com maior acessibilidade. Porém, foi identificada uma dificuldade quanto aos prazos entre receber as atividades aprovadas e realizar o upload e imprimir as atividades. Já a produção das lembrancinhas ocorreu dentro dos prazos estabelecidos semanalmente.

Diante da continuidade do isolamento social, novos problemas surgiram, além do aumento dos aspectos de gravidade, tendência e urgência dos antigos que foram considerados como itens a serem observados. Em virtude disso, uma nova MASP foi ativada.

\subsubsection{MAS Pciclo 4}

Neste ponto do estudo, a MASP acabou se tornando não apenas uma metodologia de mitigação de problemas, mas também uma técnica apurada para a escola estipular metas de curto prazo a serem alcançadas. Outro ponto analisado foi uma padronização das ferramentas utilizadas a cada ciclo da MASP ${ }^{14}$. Isso se deu pela maior adaptação da equipe a essas técnicas e por terem sido observadas como ferramentas de qualidade eficazes para o ambiente vivido.

\footnotetext{
${ }^{14}$ Considerando essa padronização, este estudo continuou com uma forma mais sucinta das ações aplicadas nos próximos ciclos. Todavia, a técnica foi apresentada na íntegra quando houve ferramentas utilizadas ou tópicos que foram considerados de maior relevância pelo pesquisador.
} 
Sendo assim, no dia 17 de maio de 2020 foi realizada uma nova reunião entre a coordenação e a direção para dar início a uma nova MASP, de modo a sanar as demandas desse período.

Durante a etapa de identificação foram detectados12 problemas por meio da técnica de brainstorming, dentre os quais seis foram priorizados. Já na etapa de observação foram levantadas as características de cada problema priorizado, conforme apresentado no Quadro 11.

Quadro 11 - Características dos problemas no ciclo 4.

\begin{tabular}{|c|c|}
\hline Problemas & Características específicas \\
\hline $\begin{array}{l}\text { Prazo curto para } \\
\text { elaboração, } \\
\text { impressão e entrega } \\
\text { para as atividades } \\
\text { remotas }\end{array}$ & $\begin{array}{l}\text { A direção está assumindo todo o setor de impressão com a } \\
\text { entrega semanal, pois não há tempo hábil para imprimir todas as } \\
\text { cópias no horário de trabalho. Logo, as impressões estão sendo } \\
\text { realizadas entre sexta-feira e domingo à noite. }\end{array}$ \\
\hline $\begin{array}{l}\text { Planejamento para } \\
\text { possível redução de } \\
\text { mensalidades }\end{array}$ & $\begin{array}{l}\text { A pressão para a redução das mensalidades aumenta a cada dia } \\
\text { devido à falta das aulas presenciais e à continuidade do } \\
\text { fechamento de muitos setores devido ao isolamento social. Os } \\
\text { responsáveis financeiros afirmam estar com dificuldades } \\
\text { financeiras. Valorizando o esforço dos responsáveis financeiros, } \\
\text { a escola precisa realizar esse planejamento e ver a possibilidade } \\
\text { de redução }\end{array}$ \\
\hline $\begin{array}{l}\text { Necessidade de } \\
\text { reposição de aulas } \\
\text { futuramente }\end{array}$ & $\begin{array}{l}\text { Com a continuidade da impossibilidade das aulas presenciais } \\
\text { está ficando pendente a carga horária a ser cumprida. Logo, } \\
\text { surge a possibilidade de precisar de aulas nos recessos e em } \\
\text { janeiro }\end{array}$ \\
\hline $\begin{array}{l}\text { Falta de orientação } \\
\text { pedagógica para os } \\
\text { pais }\end{array}$ & $\begin{array}{l}\text { Alguns pais começaram a procurar a instituição para pedir } \\
\text { orientações pedagógicas para lidar com os filhos nos momentos } \\
\text { de atividade escolar }\end{array}$ \\
\hline $\begin{array}{l}\text { Aumento da } \\
\text { inadimplência }\end{array}$ & $\begin{array}{l}\text { Com a continuidade do fechamento de muitos setores devido ao } \\
\text { isolamento social e pelo fato de os responsáveis estarem com } \\
\text { dificuldades financeiras, a inadimplência na escola começou a } \\
\text { aumentar }\end{array}$ \\
\hline $\begin{array}{l}\text { Insatisfação dos pais } \\
\text { em relaçãoàs } \\
\text { videoaulas }\end{array}$ & $\begin{array}{l}\text { As reclamações dos responsáveis dos alunos são sobre as } \\
\text { dúvidas que foram surgindo durante as videoaulas e sobre a falta } \\
\text { de interação com o professor para tirar dúvidas diretamente. }\end{array}$ \\
\hline
\end{tabular}

Fonte: Do autor, 2021.

Levantados as principais características dos problemas previamente selecionados, a próxima etapa da MASP foi analisar essas demandas. Para tanto, utilizou-se o diagrama de Ishikawa e a técnica dos cinco porquês foi utilizada duas vezes. Por meio dessas análises foram extraídas as seguintes causas raízes, conforme apresentado no Quadro 12. 
Quadro 12 - Relação dos problemas com as causas raízes.

\begin{tabular}{ll}
\hline \multicolumn{1}{c}{ Problemas } & \multicolumn{1}{c}{ Causas raízes } \\
\hline Prazo curto para impressão e & Falta de planejamento e organização de prazos \\
entrega para as atividades remotas & com os professores \\
$\begin{array}{l}\text { Planejamento para possível redução } \\
\text { de mensalidades }\end{array}$ & $\begin{array}{l}\text { Pressão do Programa Estadual de Proteção e } \\
\text { Defesa do Consumidor do Ministério Público }\end{array}$ \\
$\begin{array}{l}\text { Necessidade de reposição de aulas } \\
\text { futuramente }\end{array}$ & $\begin{array}{l}\text { Pagamento dos professores precisa ser realizado } \\
\text { de forma integral }\end{array}$ \\
$\begin{array}{l}\text { Falta de orientação pedagógica para } \\
\text { os pais de maneira individual }\end{array}$ & $\begin{array}{l}\text { Falta de organização e definição de dia para } \\
\text { atendimentos da coordenação pedagógica à } \\
\text { comunidade escolar }\end{array}$ \\
Aumento da inadimplência & $\begin{array}{l}\text { Insegurança do futuro financeiro dos pais e falta de } \\
\text { redução das mensalidades }\end{array}$ \\
Insatisfação dos pais em relação às & $\begin{array}{l}\text { Falta de interação dos alunos com o professor e } \\
\text { videoaulas }\end{array}$ \\
\hline
\end{tabular}

Fonte: Do autor, 2021.

Entre os tópicos citados no Quadro 12, vale ressaltar que a escola continuava sem fornecer aulas presenciais e mais de $50 \%$ dos responsáveis financeiros haviam solicitado redução das mensalidades. Adicionalmente, o Programa Estadual de Proteção e Defesa do Consumidor (Procon), órgão vinculado ao Ministério Público do Estado de Minas Gerais (MPMG), e os promotores de Justiça Coordenadores Regionais de Defesa do Consumidor emitiram a nota técnica № 01/2020 deliberando que todas as escolas deveriam reduzir suas mensalidades. Com isso, a pressão dos pais aumentou ainda mais.

Para uma redução consciente no valor da mensalidade da escola seria preciso uma análise detalhada de redução de custos. Adicionalmente, a não redução da mensalidade poderia gerar efeitos críticos para a escola, como: i) alto número de cancelamento de matrícula; ii) aumento do número de inadimplência; iii) insatisfação com a escola; iv) quebra de vínculo futuro e v) perda de credibilidade. Assim, concluiu-se que a falta da redução do valor da mensalidade era a causa raiz.

Sendo assim, o estudo prosseguiu para a próxima etapa da MASP,o plano de ação, que foi realizado por meio da técnica $5 \mathrm{~W} 1 \mathrm{H}$. Nessa etapa, os prazos do plano de ação foram determinados de acordo com o tempo hábil previsto para realizar cada tarefa, e as pessoas envolvidas foram os colaboradores da direção, coordenação e direção. A direção ficou responsável pela maior parte das demandas, como: a pesquisa e análise se a escola realmente era obrigada a reduzir suas mensalidades; determinar tempo de férias dos professorese montar as planilhas no 
Excel com a simulação para prever as possíveis realidades financeiras nos próximos meses da escola. Por sua vez, a coordenação e professores auxiliaram a direção a planejar os prazos da entrega das atividades remotas para impressão e tiveram uma reunião para verificaras possibilidades futuras de aulas on-line em tempo real.

$\mathrm{Na}$ etapa de execução para redução dos problemas da escola foram executadas as seguintes ações: i) a direção e coordenação reorganizaram os prazos de entrega de atividades juntamente com os professores; ii) a direção entrou em contato com o Sinep para conseguir conversar com os responsáveis financeiros dos alunos a fim de justificar a não redução das mensalidades até no momento e ficou de plantão na escola para realizar todos os atendimentos necessários; iii) a coordenação passou a atender os pais com maior frequência na escola; iv) para adquirir mais prazo para realização das aulas on-line, a escola antecipou os recessos e feriados para os alunos durante esse período; v) foram fornecidas férias de 15 dias para os professores e, durante esse período, foi encaminhada apenas uma atividade avaliativa que já tinha sido preparada juntamente com as últimas video aulas elaboradas pelos professores antes de entrarem de férias; e, por último, foi elaborada uma planilha no Excel para analisar a realidade financeira da escola.

As ações modificadas nesse ciclo MASP foram verificadas por meio de reuniões semanais e análises nas datas de entregas. Vale ressaltar que foi constatado por meio das atas de reuniões realizadas um alto índice de responsáveis financeiros procurando a escola solicitando a redução da mensalidade. Porém, averiguou-se na análise financeira que a escola teriacondições de fornecer $20 \%$ de desconto a partir da parcela da mensalidade que venceria em junho.

Em conclusão, os prazos para impressão aumentaram, facilitando a vida da direção, que, antes, trabalhava durante todo o final de semana antes das entregas. Já a pressão dos responsáveis financeiros dos alunos diminuiu, pois a escola estava bem embasada e justificada pela não redução das mensalidades de acordo com as orientações do sindicato. Em contrapartida, a necessidade de redução das mensalidades ainda erapresente na escola, por isso, a escola propôs aos pais a redução de 20 \% das mensalidades e desligou três funcionários para não ficar com suas despesas maiores que a sua receita.

A padronização dessa etapa ocorreu com a determinação das datas de entregas com maior tempo para a impressão. As mensalidades foram reduzidas em $20 \%$ até o retorno das aulas presenciais. Além disso, optou-se pelaantecipação dos 
feriados e recessos para a escola ter a possibilidade de repor as aulas sem pagamento de honorários extras para os professores.

Conforme a previsão inicial, a MASP foi aplicado mais uma vez para trabalhar as novas demandas que surgiram devido à continuidade do período pandêmico no ano de 2020 e a insatisfação dos pais em relação às video aulas não pôde ser resolvida no ciclo anterior em função da falta de tempo.

\subsubsection{MAS Pciclo 5}

O quinto ciclo teve seu início no dia 8 de julho de 2020. Durante essaetapa foram identificados 12 problemas utilizando a técnica de brainstorming, dentre os quaisquatro foram priorizados utilizando a matriz GUT. Os quatro problemas selecionados podem ser observados no Quadro 13.

Quadro 13 - Características dos problemas no ciclo 5.

\begin{tabular}{ll}
\hline \multicolumn{1}{c}{ Problemas } & \multicolumn{1}{c}{ Características específicas } \\
\hline $\begin{array}{l}\text { Falta de controle que os } \\
\text { responsáveis estão } \\
\text { realmente recebendo } \\
\text { informações }\end{array}$ & $\begin{array}{l}\text { Uma das exigências da secretaria de educação é que a } \\
\text { escola tenha o controle dos alunos que estão assistindo às } \\
\text { aulas }\end{array}$ \\
$\begin{array}{l}\text { Insatisfação dos pais em } \\
\text { relaçãoàs videoaulas }\end{array}$ & $\begin{array}{l}\text { As reclamações dos responsáveis dos alunos são sobre as } \\
\text { dúvidas que foram surgindo durante as videoaulas e a falta } \\
\text { de interação com o professor para tirar dúvidas diretamente }\end{array}$ \\
$\begin{array}{l}\text { As videoaulas não proporcionaram uma boa relação entre } \\
\text { aluno e professor, pois o aluno não tinha como conversar, }\end{array}$ \\
$\begin{array}{l}\text { serem mais próximas da } \\
\text { realidade dos momentos } \\
\text { presenciais }\end{array}$ & $\begin{array}{l}\text { tirar dúvidas e participar das aulas de forma ativa. Foi } \\
\text { observado também a queda da entrega de atividades } \\
\text { remotas realizadas pelos alunos. Adicionalmente, os alunos } \\
\text { ficaram com mais tempo ocioso durante o dia, perdendo o } \\
\text { ritmo da rotina escolar }\end{array}$ \\
Falta de reunião de pais & $\begin{array}{l}\text { Onúmero de reclamações aumentando e a necessidade de } \\
\text { melhor posicionamento da escola configurou como } \\
\text { necessário um momento de reunião de pais }\end{array}$ \\
\hline
\end{tabular}

Fonte: Do autor, 2021.

Para realizar a análise dos problemas selecionados foram utilizados novamente o diagrama de Ishkawa ea técnica dos cinco porquês. A primeira e a última demanda tiveram suas causas raizes relacionadas, que foram respectivamente: a relação entre família e escola fica instável por falta de informações das ações da escola e falta de feedback dos pais para escola. Sendo assim, o estudo observou que a causa raiz dos dois problemas se unia pela falta de boa comunicação entre escola e família. Já os problemas de insatisfação dos pais 
em relaçãoàs video aulas e a necessidade de as aulas serem mais próximas da realidade dos momentos presenciais apresentaram também as causas raízes relacionadas, pois as duas solicitavam a melhoria da qualidade de aula fornecida pela escola.

O plano de ação elaborado para esse ciclo resultou na contratação de um aplicativo de comunicação escolar que funcionava como uma agenda eletrônica, tendo a direção e a coordenação ficado responsáveis por ele. Nesse momento também foi necessário marcar uma reunião de pais on-line. A direção da escola, a partir do plano de ação, também contratou uma plataforma que tinha a funcionalidade de oferecer aulas on-line em tempo real. Paralelamente às contratações foram realizados treinamentos aos coloboradores que as utilizariam.

Foram elaborados dois fluxogramas para exemplificar a etapa de execução da MASP, conforme pode ser observado na Figura 21. 
Figura 21 - Fluxogramas da contratação da agenda eletrônica e da contratação do programa para fornecer aulas on-line.

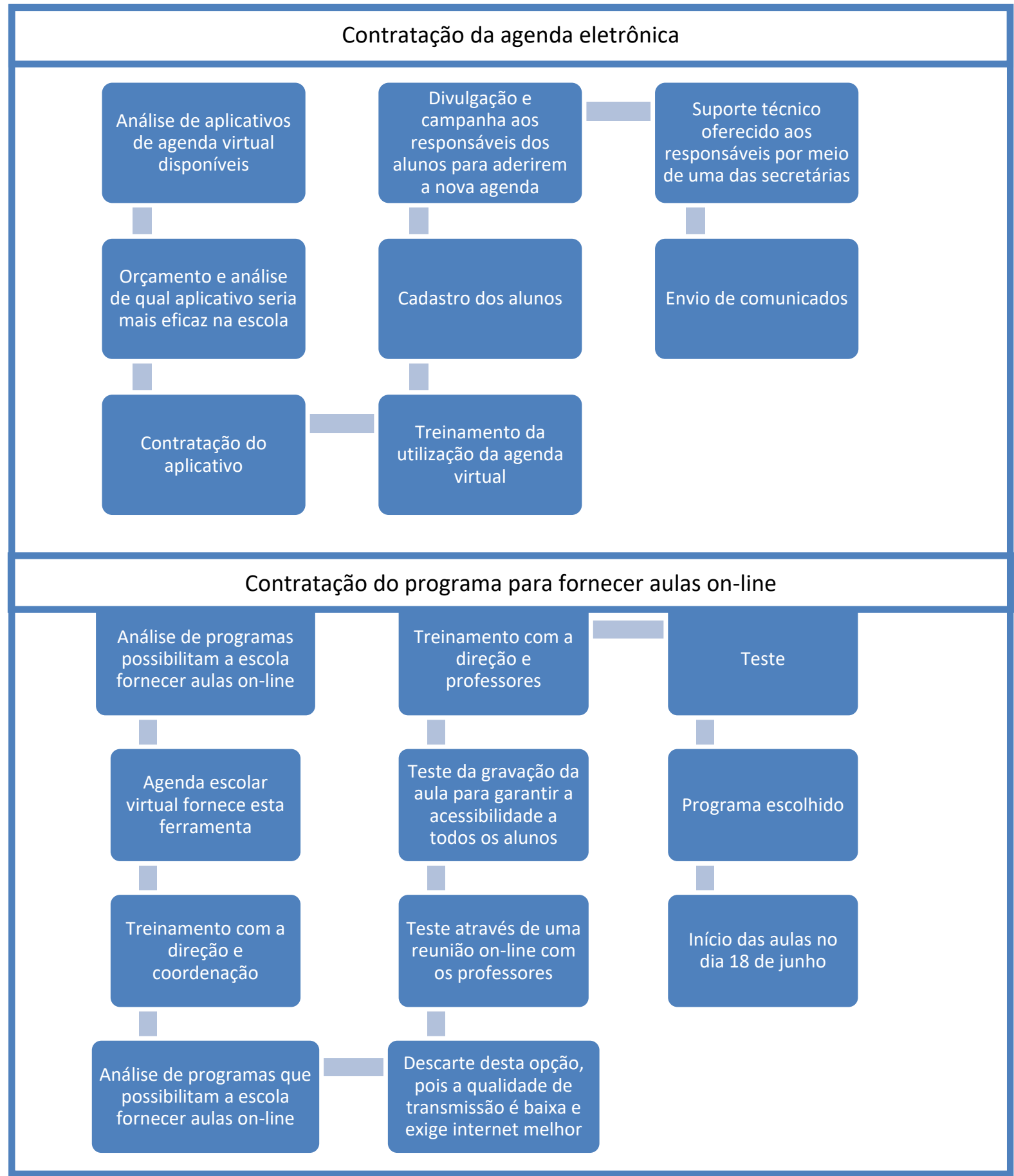

Fonte: Do autor, 2021.

Conforme apresentado na Figura 21, a contratação do primeiro programa para fornecer aulas on-line deu errado, de modo que foi necessário buscar outra alternativa.

A utilização da agenda eletrônica permitiu a verificação do recebimento das informações pelos responsáveis e se a mensagem que foi enviada pela escola foi 
lida. Já a verificação da presença na aula on-line foi realizada pela chamada em sala de aula ou pelos envios das aulas gravadas. A padronização ocorreu nesse ciclo com o auxílio dos programas utilizados na escola. A partir desse momento, a escola passou a possuir um meio de comunicação direto com as famílias dos alunos e obteve a garantia de que eles tiveram acesso às mensagens. Outro ponto importante foi a mudança das aulas fornecidas pela escola, que, antes, eram por video aulas e passaram a ser aulas aovivo e gravadas para os alunos que não pudessem participar.

Em conclusão ao quinto ciclo da MASP aplicado no período de isolamento social, as duas contratações foram consideradas benéficas para a escola, pois o retorno dos responsáveis dos alunos foi positivo, tendo a escola recebido três novos alunos para participar do ensino remoto oferecido. Além disso, foi fornecida uma condição mais tranquila para os colaboradores trabalharem, pois o número de reclamações reduziu significativamente. Dado o cenário, partiu-se para ociclo $6 \mathrm{da}$ MASP.

\subsubsection{MAS Pciclo 6}

O ciclo 6 teve o maior período de tempo para realização da MASP. Ele foi iniciado no dia 6 de julho e seu término foi no dia 23 de novembro de 2020. Dessa forma, esse ciclo foi fundamental para organização do final do ano letivo na escola, embora ele não tenha abordado o final das atividades letivas.

Nesse ciclo foram identificados 12 problemas por meio da técnica de brainstorming, dentre os quais quatro foram priorizados através da matriz GUT: i) falta do sistema de avaliação de término da etapa; ii) necessidade de fazer as planilhas de acordo com as exigências da Secretaria de Educação; iii) falta de organização na correção das atividades remotas; e iv) falta de demonstração de continuidade das atividades na escola. Adicionalmente, foram levantadas as características dos problemas em questão a fim de entender melhor as variáveis relacionadas.

$\mathrm{Na}$ etapa da análise foram analisados os problemas a fim de se descobrir a causa raíz de cada um deles. As causas podem ser observadas no Quadro 14. 
Quadro 14 - Características dos problemas no ciclo 6.

\begin{tabular}{|c|c|}
\hline Problemas & Características específicas \\
\hline Falta do sistema de avaliação & Impossibilidade de seguir com o conteúdo \\
\hline $\begin{array}{l}\text { Necessidade de fazer as planilhas de acordo } \\
\text { com as exigências da Secretaria de Educação }\end{array}$ & Orientação necessária \\
\hline $\begin{array}{l}\text { Falta de organização na correção das } \\
\text { atividades remotas }\end{array}$ & $\begin{array}{l}\text { Falta de plano de metas de curto prazo } \\
\text { para as professoras }\end{array}$ \\
\hline $\begin{array}{l}\text { Falta de demonstração de continuidade das } \\
\text { atividades na escola }\end{array}$ & Falta de movimento na faixada da escola \\
\hline
\end{tabular}

Fonte: Do autor, 2021.

Diante das causas raízes, os problemas em questão foram trabalhados seguindo um plano de ação por meioda ferramenta $5 \mathrm{~W} 1 \mathrm{H}$, conforme pode ser observado no Quadro 15. 
Quadro $15-5$ W1H do ciclo 6 .

\begin{tabular}{|c|c|c|c|c|c|c|}
\hline \multirow{2}{*}{$\begin{array}{c}\text { Solução / } \\
\text { O que (What) }\end{array}$} & \multicolumn{2}{|c|}{ Quando (When) } & \multirow{2}{*}{$\begin{array}{c}\text { Onde } \\
\text { (Where) }\end{array}$} & \multirow{2}{*}{$\begin{array}{l}\text { Quem } \\
\text { (Who) }\end{array}$} & \multirow{2}{*}{$\begin{array}{l}\text { Por que } \\
\text { (Why) }\end{array}$} & \multirow{2}{*}{$\begin{array}{l}\text { Como } \\
\text { (How) }\end{array}$} \\
\hline & Início & Fim & & & & \\
\hline $\begin{array}{l}\text { Falta do sistema de } \\
\text { avaliação de } \\
\text { término da etapa }\end{array}$ & $\begin{array}{l}\text { Início das } \\
\text { pesquisas, } \\
\text { antes do } \\
\text { processo } \\
\text { da MASP } \\
29 / 06 \\
\end{array}$ & $20 / 07$ & $\begin{array}{l}\text { Home } \\
\text { office }\end{array}$ & $\begin{array}{l}\text { Direção, } \\
\text { coordenação e } \\
\text { professores }\end{array}$ & $\begin{array}{l}\text { - Analisar o rendimento dos } \\
\text { alunos; } \\
\text { - Observar a necessidade de } \\
\text { revisão de algum conteúdo; } \\
\text { - Finalizar a etapa }\end{array}$ & $\begin{array}{l}\text { - Analisar quais são as práticas } \\
\text { utilizadas em outras instituições; } \\
\text { - Procurar informações do que } \\
\text { está dando certo e o que está } \\
\text { dando errado; } \\
\text { - Adaptar à realidade da escola }\end{array}$ \\
\hline $\begin{array}{c}\text { Necessidade de } \\
\text { fazer as planilhas } \\
\text { de acordo com as } \\
\text { exigências da } \\
\text { Secretaria de } \\
\text { Educação } \\
\end{array}$ & $10 / 07$ & $31 / 07$ & $\begin{array}{l}\text { Home } \\
\text { office }\end{array}$ & $\begin{array}{l}\text { Coordenação e } \\
\text { professores }\end{array}$ & $\begin{array}{l}\text { - Necessário para validação do } \\
\text { ensino remoto utilizado nas aulas. }\end{array}$ & $\begin{array}{c}\text { Participar da reunião on-line de } \\
\text { orientação ao preenchimento da } \\
\text { documentação necessária } \\
\text { fornecida pela Secretaria de } \\
\text { Educação e orientação dos } \\
\text { professores } \\
\end{array}$ \\
\hline $\begin{array}{c}\text { Falta de } \\
\text { organização na } \\
\text { correção das } \\
\text { atividades remotas }\end{array}$ & 06/07 & $23 / 11$ & $\begin{array}{l}\text { Sala de } \\
\text { aula do } \\
5^{\circ} \text { ano }\end{array}$ & $\begin{array}{l}\text { Direção, } \\
\text { coordenação e } \\
\text { professores }\end{array}$ & $\begin{array}{c}\text { - Necessário para estabelecer o } \\
\text { retorno das atividades corrigidas } \\
\text { para os pais; } \\
\text { - Acompanhar melhor os } \\
\text { professores durante as correções; } \\
\text { - Coordenação pedagógica ter } \\
\text { material para analisar o } \\
\text { desenvolvimento dos alunos de } \\
\text { cada turma e auxiliar nas } \\
\text { reuniões semanais }\end{array}$ & $\begin{array}{l}\text { Realizar um plano de ação } \\
\text { utilizando a ferramenta } \\
\text { fluxograma }\end{array}$ \\
\hline $\begin{array}{c}\text { Falta de } \\
\text { demonstração de } \\
\text { continuidade das } \\
\text { atividades na } \\
\text { escola }\end{array}$ & $20 / 07$ & $25 / 08$ & $\begin{array}{l}\text { Home } \\
\text { office e } \\
\text { portaria } \\
\text { da } \\
\text { escola }\end{array}$ & $\begin{array}{l}\text { Coordenação e } \\
\text { professores }\end{array}$ & $\begin{array}{l}\text { - Pouca procura na escola de } \\
\text { alunos novatos; } \\
\text { - Reclamações dos responsáveis } \\
\text { de possíveis alunos, pois ficaram } \\
\text { sabendo do funcionamento com } \\
\text { outros responsáveis de alunos já } \\
\text { matriculados na escola }\end{array}$ & Projeto Portão da Esperança \\
\hline
\end{tabular}

Fonte: Do autor, 2021. 
$\mathrm{Na}$ etapa de execução foram elaborados dois fluxogramas para organizar a falta do sistema de avaliação de término da etapa e a necessidade de fazer as planilhas de acordo com as exigências da Secretaria de Educação com o passo a passo a ser seguido de ações administrativas. Em contrapartida, para afalta de organização na correção das atividades remotas precisou ser elaborado um calendário de metas emcurto prazo para os professores pelo qualeles saberiam cada tarefa que precisavam realizar emcada intervalo de tempo. E, por último, foi montada uma escala para cada professor fazer um mural para o portão da escola até o final do ano, no chamado Projeto Portão da Esperança.

A verificação das ações realizadas foi feita nas reuniões semanais com a direção e com a coordenação e nas reuniões da coordenação com o professor em questão. Na etapa de padronização, os sistemas de avaliações da escola foram realizados no mesmo formato do primeiro e segundo trimestres. A escola recebeu elogios de responsáveis dos alunos quanto a essa organização. Já a entrega das planilhas foi padronizada para toda segunda-feira para a análise da coordenação.

A reorganização das entregas por datas proporcionou uma caminhada mais precisa durante esse período do ciclo. Sendo assim, a coordenação e a direção ficaram responsáveis pororganizar todas as datas de entrega até o final do ano letivo. E o Portão da Esperança foi divido de modo que cada professor fizesse o mural uma única vez.

Em resumo, a falta do sistema de avaliação de término da etapa foi solucionada e a escola recebeu muitos elogios pela credibilidade em deixar as avaliações com os responsáveis dos alunos. Outro ponto destacado foi a consideração para que os alunos não perdessem pontos devido a falhas tecnológicas.

A elaboração das planilhas de acordo com as exigências da Secretaria de Educação foi organizada e os professores receberam o aparato necessário para o desenvolvimento. Complementarmente foi elaborado um calendário incluindo as metas dos professores em cada período para auxiliar na organização da correção das atividades remotas e outras atividades afins, como o Portão da Esperança. Esse projeto foi importante por ter proporcionado maior interação e socialização com a comunidade escolar, tendo muitos alunos tirado fotos e postado nas redes sociais da escola, além de demonstrar a toda comunidade a continuidade das atividades na escola. Sendo assim, o estudo caminhou para o seu último ciclo MASP. 


\subsubsection{MAS Pciclo 7}

O último ciclo MASP abordado neste trabalho foi iniciado no dia 24 de novembro de 2020 e terminou no dia 23 de fevereiro de 2021. Nesse ciclo também foi utilizada a técnica de brainstorming para identificar os problemas referentes à matrícula e ao retorno das aulas presenciais. Adicionalmente, a matriz GUT foi utilizada para priorizar os problemas considerados mais graves, tendenciosos e urgentes, conforme pode ser observado no Quadro 16, que apresenta também as características específicas que fazem parte da etapa de observação da MASP.

Quadro 16 - Características dos problemas no ciclo 7.

\begin{tabular}{|c|c|}
\hline Problemas & Características específicas \\
\hline $\begin{array}{l}\text { Contrato } \\
\text { ultrapassado }\end{array}$ & $\begin{array}{l}\text { O contrato da instituição precisa ser reformulado devido à realidade } \\
\text { da pandemia, de modo a resguardar a escola de possíveis } \\
\text { acontecimentos que possam ocorrer ainda no ano de } 2021 \text {, além } \\
\text { de possuir algumas cláusulas divergentes ou confrontantes }\end{array}$ \\
\hline $\begin{array}{l}\text { Falta de definição } \\
\text { do valor da } \\
\text { mensalidade no ano } \\
\text { de } 2021\end{array}$ & $\begin{array}{l}\text { A definição do valor da mensalidade é sempre um desafio da } \\
\text { escola, pois a instituição precisa equilibrar a possível receita da } \\
\text { instituição com a previsão de alunos no próximo ano. } \\
\text { Adicionalmente, a saída financeira da escola é alta devido aos } \\
\text { encargos, salários, impostos, despesas físicas e investimentos em } \\
\text { melhorias }\end{array}$ \\
\hline $\begin{array}{l}\text { Financeiro no } \\
\text { vermelho }\end{array}$ & $\begin{array}{l}\text { Uma empresa, independentemente do seguimento que atua, } \\
\text { precisa se manter financeiramente saudável }\end{array}$ \\
\hline $\begin{array}{l}\text { Definição tardia dos } \\
\text { livros para adotar } \\
\text { em } 2021\end{array}$ & $\begin{array}{l}\text { Os livros do Ensino Fundamental na instituição são analisados e } \\
\text { definidos anualmente, a fim de estar sempre em consonância com } \\
\text { novidades e processos pedagógicos atualizados. Porém, é uma } \\
\text { prática que demanda tempo, principalmente da direção, por isso há á } \\
\text { a necessidade de um planejamento para que a resposta seja mais } \\
\text { rápida e efetiva. Em adição, o problema se agrava pela } \\
\text { necessidade de definição rápida e precisa }\end{array}$ \\
\hline $\begin{array}{l}\text { Falta de protocolo } \\
\text { caso haja retorno } \\
\text { das aulas }\end{array}$ & $\begin{array}{l}\text { Esse é um fator externo da instituição, por isso, é necessário } \\
\text { determinar uma linha de atuação até onde a escola pode investir } \\
\text { e/ou se preparar para um possível retorno das aulas presenciais. }\end{array}$ \\
\hline
\end{tabular}

Fonte: Do autor, 2021

$\mathrm{Na}$ etapa de análise foram utilizadosa técnica dos cinco porquês e o diagrama de Ishikawa para encontrar as causas raízes dos problemas. Na demanda do contrato ultrapassado, a causa raíz foi o alto risco de gastos desnecessários não previstos no contrato. Já quanto à falta de definição do valor da mensalidade no ano de 2021, a causa raíz foi a possível perda de alunos para a concorrência. O alto 
número de colaboradores foi o principal motivo do financeiro da escola estar no vermelho. Em adição, a tardia escolha dos livros a serem adotados em 2021 apresentou a alta possibilidade de adotar o mesmo livro do ano anterior sem análise completa como sua principal causa. E, por fim, foi realizada uma análise para o protocolo aser exigido pelos órgãos competentes, conforme apresentado na Figura 22.

Figura 22 - Diagrama de Ishikawa para falta de protocolo caso haja retorno das aulas.

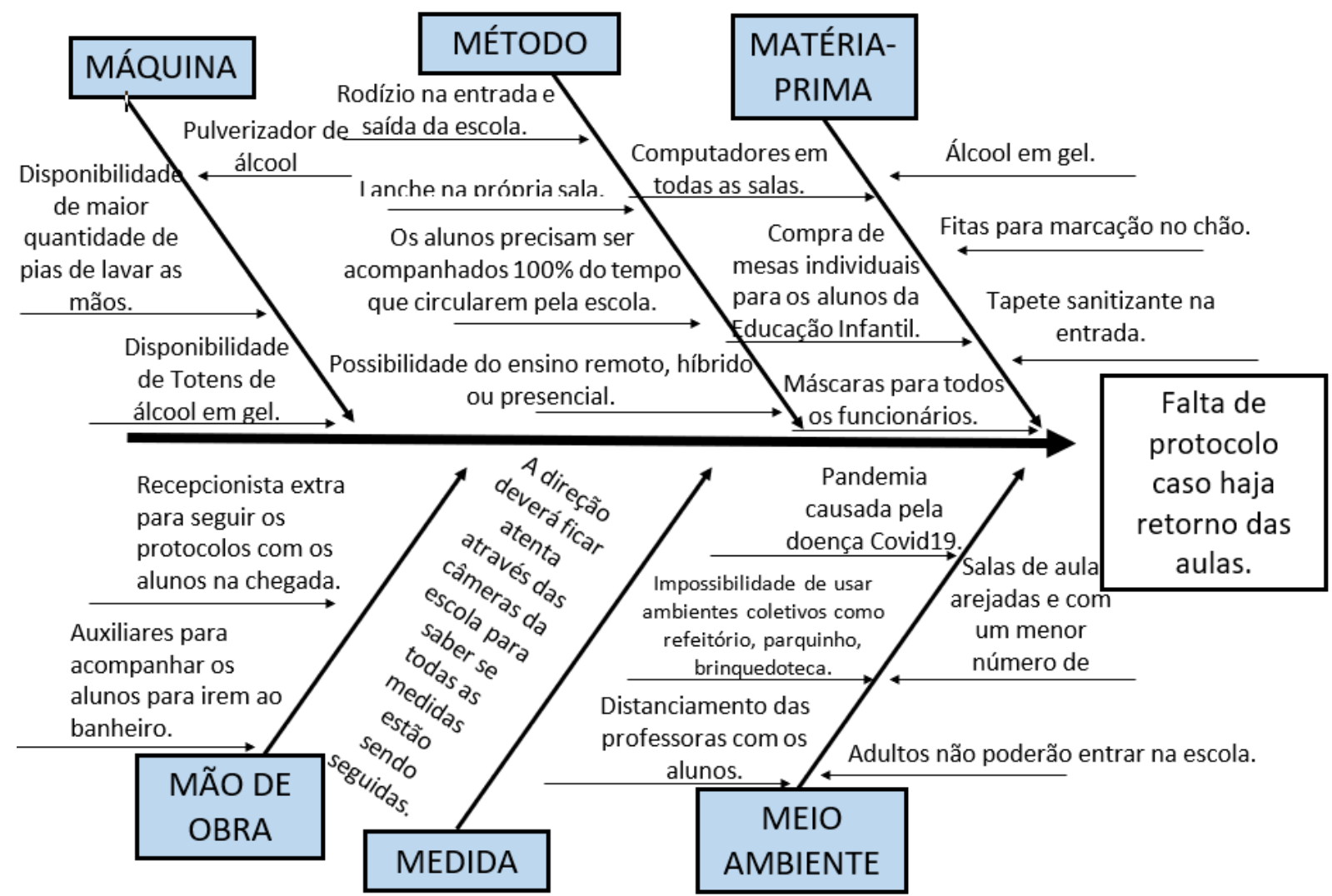

Fonte: Do autor, 2021.

Após analisar as variáveis apresentadas na Figura 22 foi determinado que a causa raíz do problema era a insegurança das medidas a serem tomadas com aulas presencias em relação à prevenção à Covid-19.

Para elaboração doplano de ação foi utilizada a metodologia 5W1H, conforme apresentado no Quadro 17. 
Quadro $17-5 \mathrm{~W} 1 \mathrm{H}$ do ciclo 7.

\begin{tabular}{|c|c|c|c|c|c|c|}
\hline \multirow{2}{*}{$\begin{array}{c}\text { Solução / } \\
\text { O que } \\
\text { (What) }\end{array}$} & \multicolumn{2}{|c|}{ Quando (When) } & \multirow{2}{*}{$\begin{array}{c}\text { Onde } \\
\text { (Where) }\end{array}$} & \multirow{2}{*}{$\begin{array}{l}\text { Quem } \\
\text { (Who) }\end{array}$} & \multirow{2}{*}{$\begin{array}{l}\text { Por que } \\
\text { (Why) }\end{array}$} & \multirow{2}{*}{$\begin{array}{l}\text { Como } \\
\text { (How) }\end{array}$} \\
\hline & Início & Fim & & & & \\
\hline $\begin{array}{c}\text { Contrato } \\
\text { ultrapassado }\end{array}$ & $\begin{array}{c}\text { Início das } \\
\text { pesquisas } \\
\text { antes do } \\
\text { processo } \\
\text { da MASP. } \\
16 / 11\end{array}$ & $26 / 11$ & $\begin{array}{l}\text { Home } \\
\text { office }\end{array}$ & $\begin{array}{c}\text { Direção } \\
\text { (Pessoa } \\
\text { A e B) }\end{array}$ & $\begin{array}{c}\text { - Contrato não } \\
\text { cobre a maioria } \\
\text { das } \\
\text { possibilidades } \\
\text { recorrentes no } \\
\text { dia a dia da } \\
\text { escola, ou seja, } \\
\text { a escola fica } \\
\text { vulnerável a } \\
\text { processos }\end{array}$ & $\begin{array}{c}\text { - O Sinep, } \\
\text { juntamente com } \\
\text { seus advogados, } \\
\text { montou um } \\
\text { documento com } \\
\text { possíveis cláusulas } \\
\text { que as escolas } \\
\text { poderiam precisar. } \\
\text { Logo, é necessário } \\
\text { realizar a leitura e } \\
\text { reestruturar o } \\
\text { contrato da } \\
\text { instituição de } \\
\text { maneira completa }\end{array}$ \\
\hline $\begin{array}{c}\text { Falta de } \\
\text { definição do } \\
\text { valor da } \\
\text { mensalidade } \\
\text { no ano de } \\
2021\end{array}$ & $27 / 11$ & $30 / 11$ & $\begin{array}{l}\text { Sala de } \\
\text { aula do } \\
5^{\circ} \text { ano }\end{array}$ & $\begin{array}{c}\text { Direção } \\
\text { (Pessoa } \\
\text { A) }\end{array}$ & $\begin{array}{c}\text { - Insegurança } \\
\text { dos } \\
\text { responsáveis, } \\
\text { gerando, assim, } \\
\text { uma } \\
\text { insatisfação. Em } \\
\text { conclusão, pode } \\
\text { ocasionar } \\
\text { perdas de } \\
\text { alunos }\end{array}$ & $\begin{array}{l}\text { - Planilhas de } \\
\text { controle financeiros } \\
\text { que deem a } \\
\text { possibilidade de } \\
\text { previsões futuras }\end{array}$ \\
\hline $\begin{array}{l}\text { Financeiro } \\
\text { no vermelho }\end{array}$ & & & & & $\begin{array}{l}\text { - Perigo da } \\
\text { escola entrar } \\
\text { em falência }\end{array}$ & \\
\hline $\begin{array}{c}\text { Definição } \\
\text { tardia dos } \\
\text { livros para } \\
\text { adotar em } \\
2021\end{array}$ & $01 / 12$ & $11 / 12$ & $\begin{array}{l}\text { Sala de } \\
\text { aula do } \\
5^{\circ} \text { ano }\end{array}$ & $\begin{array}{c}\text { Direção } \\
\text { (Pessoa } \\
\text { A e B) }\end{array}$ & $\begin{array}{l}\text { - Pouca análise } \\
\text { de outros livros }\end{array}$ & $\begin{array}{c}\text { - Analisar os livros } \\
\text { já disponíveis na } \\
\text { escola, conversar } \\
\text { com representante } \\
\text { das editoras, } \\
\text { levantar análises } \\
\text { de anos anteriores } \\
\text { dos livros e } \\
\text { negociação } \\
\text { financeira } \\
\end{array}$ \\
\hline $\begin{array}{c}\text { Insegurança } \\
\text { das medidas } \\
\text { a serem } \\
\text { tomadas em } \\
\text { combate ao } \\
\text { Covid19 com } \\
\text { aulas } \\
\text { presencias }\end{array}$ & $12 / 12$ & $16 / 01$ & $\begin{array}{l}\text { Home } \\
\text { office e } \\
\text { escola }\end{array}$ & $\begin{array}{l}\text { Direção } \\
\text { (Pessoa } \\
\text { A, B e } \\
\text { C) }\end{array}$ & $\begin{array}{c}\text { - Necessidade } \\
\text { de seguir as leis } \\
\text { estabelecidas } \\
\text { pelo Comitê } \\
\text { Municipal contra } \\
\text { a Covid-19. } \\
\text { - A escola pode } \\
\text { não ter tempo } \\
\text { de fazer as } \\
\text { adaptações } \\
\text { quando liberar } \\
\text { as aulas } \\
\text { presenciais }\end{array}$ & $\begin{array}{c}\text { - Análise de } \\
\text { orientações de } \\
\text { outras cidades, } \\
\text { assim como da } \\
\text { OMS }\end{array}$ \\
\hline
\end{tabular}

Fonte: Do autor, 2021.

Sendo assim, o plano de execução ocorreu com a elaborção de fluxogramas para realizar cada etapa de maneira clara e bem definida. Porém, a falta do 
protocolo exigiu um pouco mais de trabalho devido à quantidade de variáveis apresentadas no diagrama de Ishikawa, necessitando de uma tabela baseada na metodologia $5 \mathrm{~W} 1 \mathrm{H}$ para exclarecer melhor cada etapa.

A verificação do contrato foi realizada por uma terceira pessoa a qual trabalha na direção da escola, tendo sido realizadas ligações para o setor jurídico do SinepMG para solicitar auxílio. Além disso, as secretárias da escola também fizeram a leitura para verificar se houve algum erro e também para ficarem a pardas informações para realizar atendimentos aos pais.

Com a determinação do valor da mensalidade e a escolha dos livros definida não foi necessário realizar a verificação. E, por fim, o protocolo de retorno às aulas presenciais foi realizado com o auxílio de checklist e apresentando seu andamento nas reuniões semanais.

O contrato a partir doano de 2021 foirevisto de acordo com as orientações do Sinep-MG para que ele não ficassetão desatualizado como aconteceu.Assim,foram acrescentadas trêspáginas no contrato e mais um termo aditivo com duas páginas para resguardar a escola.

A definição de adoção dos livros para o próximo ano terá um padrão a ser seguido e espera-se que a direção da escola tire um tempo em outubro para fazer todo o processo. Já a definição da mensalidade também ficará para ser analisada nos meses de outubro, assim a direção terá mais tranquilidade para trabalhar no final do ano. Todavia, como o protocolo oficial demorou a ser divulgado, a escola ainda não estabeleceu um padrão.

Para concluir, o contrato foi elaborado de maneira clara, objetiva e mais segura. Isso forneceu mais segurança aos responsáveis pelos alunos e pela escola. Em adição, foi definido que a mensalidade não seria alterada, porém o corpo de funcionários foi reduzido.

Já a definição dos livros didáticos que foram adotados para 2021 foi realizada de maneira corrida e, por isso, a escola precisa se programar melhor no próximo ano. Além disso, mesmo o protocolo sendo emitido tardiamente, a escola já iniciou ações prévias de modo a possibilitar o retorno das aulas assim que houver a liberação pelos órgãos competentes. 


\section{CAPÍTULO 06 \\ CONSIDERAÇÕES FINAIS}

A MASP tem a capacidade de auxiliar diferentes empresas em diferentes setores com o objetivo de identificar, observar, analisar, planejar, agir, checar e padronizar novos processos eliminando ou reduzindo problemas. Em adição, ferramentas de qualidade como brainstorming, diagrama de Ishikawa, técnica dos cinco porquês, fluxograma, $5 \mathrm{~W} 1 \mathrm{H}$ e Matriz GUT aplicadas de forma organizada como a MASP podem auxiliá-la em cada etapa de seu ciclo.

Cada ciclo aplicado da MASP na escola auxliou em diferentes áreas. No ciclo 1, a metodologia auxiliou na implementação de um meio de comunicação em grande escala da escola com as famílias dos alunos, no fornecimento do acompanhamento pedagógico aos pais e na elaboração e entrega das atividades.

No ciclo 2, a MASP ajudou na melhorada relação entre escola e família, na orientação sobre as leis, na escolha do programa e na realização das primeiras aulas on-line e no atendimento da secretaria e direção da escola.

Vale ressaltar que durante o período de isolamento social ficou claro também que a utilização das tecnologias de informação e comunicação foram fundamentais para a continuidade do trabalho com as famílias e, principalmente, para promover conhecimento e desenvolvimento para os alunos.

No ciclo 3, a MASP deu suporte para iniciar o novo modelo de aula on-line, do qual $100 \%$ dos alunos puderam ter acesso. Em adição, ainda no mesmo ciclo, melhorou a comunicação, de modo que os responsáveis pelos alunos puderam conversar sobre o setor financeiro com a direção da escola, melhorou também o controle das atividades enviadas e aumentou a acessibilidade a elas. Por fim, a elaboração das lembrancinhas do dia das mães, que era um desafio devido ao prazo, foi realizada de forma organizada e em tempo hábil.

No ciclo 4, a metodologia amparou na organização da entrega e impressão das atividades, na diminuição dos problemas financeiros com a redução das mensalidades e na antecipação dos feriados e recessos para a escola ter a possibilidade de repor as aulas sem pagamento de honorários extras para os professores. 
No ciclo 5, vale ressaltar que a contratação da agenda virtual e do programa para fornecer aulas on-line teve um impacto positivo entre os pais diante do retorno por mensagens e em reuniões com a direção e coordenação. Além disso, a escola recebeu três novos alunos. Essas ações possibilitaram um ambiente de maior tranquilidade para os colaboradores trabalharem.

Já no ciclo 6, a MASP auxiliou na organização, elaboração e na aplicação do sistema de avaliação, na organização da produção de planilhas com planos das aulas de acordo com as exigências da Secretaria de Educação, na organização da correção das atividades remotas realizadas pelos professores e na criação, elaboração e montagem do Portão da Esperança.

E, por último, no ciclo 7, a MASP deu suporte no setor de matrícula e no possível reinício das aulas presenciais em 2021, tendo amparado na elaboração do contrato a fim de minimizar problemas futuros, na defnição do valor da mensalidade de 2021, na definição dos livros didáticos e no início das modificações que a escola precisa realizar para retornar suas atividades presenciais de acordo com o protocolo emitido pelos órgãos competentes.

Em suma, este trabalho proporcionou uma melhor organização na escola na qual a MASP foi implementanda, identificando e minimizando problemas. Com isso, possibilitou melhores reflexões sobre a real situação vivida no período pandêmico e auxiliou para tomadas de decisão com melhor qualidade.

A principal limitação encontrada nesta pesquisa foi a falta de levantamento de dados quantitativos devido a escola não ter conseguido coletar uma quantidade maior de dados para realização de mais análises.

Para trabalhos futuros, este estudoproporciona uma reflexão sobre utilizar a MASP em outras áreas da educação, como: reorganização de setores financeiros de escolas, desenvolvimento de aprendizagem do aluno, sistema de informação, organização de processos de atendimentos nas secretarias e trabalhar nas áreas de gestão e coordenação. 


\section{REFERÊNCIAS}

AQUINO, M. S. T.et al., Implantação de fluxograma de atendimento em um centro de atenção psicossocial. Revista Brasileira em Promoção a Saúde, v. 30, n. 2, p.288293, 2017.

ALVES, M. Perspectivas da escola católica no Brasil. Diálogo Educacional, Curitiba, v. 6, n. 19, p.127-140, set./dez. 2006.

ANDRADE, R. S.; RODRIGUES, A. Implementação da Metodologia de Análise e Solução de Problemas (MASP) para redução de perdas em empresas manufatureiras. Revista da Universidade Vale do Rio Verde, v. 15, n. 1, p.73-82, jan./jul. 2017.

BITTENCOURT, B.; CASTRO M. M. Atravessamentos na pandemia: relatos maternos sobre moradia, escola e pesquisa. Revista Práxis, v. 12, n. 1, dez. 2020.

BONNARDEL, N.; DIDIER J. Brainstorming variants to favor creative design. Applied Ergonomics, v.83, dez. 2020.

CAMPOS, C. M. Gestão escolar e docência. São Paulo: Paulinas, 2010.

CARPINETTI, L. C. R. Gestão da qualidade: conceitos e técnicas. 2. ed. São Paulo: Atlas, 2012.

COUTINHO, C. M. F. TICs nas escolas públicas: mais um fator para a desigualdade? Revista Atlante, on-line, 2018. Disponível em: https://www.eumed.net/rev/atlante/2018/04/tics-escolas-publicas.html Acesso em: 26 set. 2020.

COSTA, A. M. Engenharia de métodos e tempos aplicada no processo de produção de estruturas metálicas. Destaques Acadêmicos, v. 12, n. 4, p.194-215, 2020.

CZERWIŃSKA K.; DWORNICKA R.; PACANA A. Improvement of the surface of the combustion chamber of a piston using selected techniques of production organization. Materials Research Proceedings, v.17, p. 270-275, 2020.

DANES, J. E.; MULLIKIN, J. L.; LERTWACHARA, K. The sequential order and quality of ideas in electronic brainstorming. International Journal of Information Management, v. 53, dez. 2019.

DEMING, W. E. Qualidade: a revolução da administração. São Paulo: Marques Saraiva, 1990.

DIAS, N. F. C.; MELÃO, N. F. R. Avaliação e qualidade: dois conceitos indissociáveis na gestão escolar. Revista de Estudos Politécnicos. v. 7, n. 12, p. 193-214, 2009. 
DINKAR, R. T. The improvement of manufacturing process by using quality tools. International Journal of Engineering Research \& Science, v. 5, n. 3, 2020.

FACCI, M. J. Manutenção produtiva total: proposta de aplicação em um terminal de distribuição de combustíveis. 2015. 46f. Trabalho de Conclusão de Curso (Engenharia de Produção) - Universidade Estadual de Maringá, Paraná, 2015.

FERREIRA, M. F. T.; PEREIRA, A. S. Gestão escolar e participação: a percepção dos alunos. Revista de Iniciação Científica. v. 15, n. 2, Criciúma, 2017.

HENRIQUE, A. R. P. Escola particular em Juiz de Fora: o uso das TIC na prática docente do $9^{\circ}$ ano do ensino fundamental. In: CONGRESSO INTERNACIONAL DE LINGUAGEM E TECNOLOGIA ON-LINE, 13, Anais [...], v. 5, n. 1, junho/2016.

KERBES, A. Gestão escolar: indicadores de boas práticas em escolas privadas no Brasil. 2018. 164f. Dissertação de Mestrado (Pós-Graduação em Educação) Universidade La Salle, Canoas, Rio Grande do Sul, 2018.

KULIŠ, M. Š.; HODŽıĆ, S. The research of manager's perception about the importance of quality management tools and techniques at Croatian companies. International Economics, Finance \& Business Conference, v. 18, p. 81-94, set. 2020.

LEMOS JUNIOR, W. J. F.et al. Reuse of refillable PET packaging: approaches to safety and quality in soft drink processing. Food Control, v. 100, p. 329-334, 2019.

LORENZON, E; DIEDRICH, H. Utilização do MASP (Método de Análise e Solução de Problemas) em uma granja de suínos. Revista Destaques Acadêmicos, v. 11, n. 1, p. 25-47, 2019.

LUCINDA. M. A. Qualidade: fundamentos e práticas para cursos de graduação. Rio de Janeiro: Brasport, 2010.

MACHADO, V. A. D.; ZOLA, F. C. Método de análise e soluções de problemas MASP: estudo de caso em uma indústria alimentícia. 2016. 57f. Trabalho de Conclusão de Curso (Engenharia de Produção) - Universidade Estadual de Maringá, Paraná, 2016.

MARTINS, A. C. A.et al. Method of problem analysis and solving applied to quality and productivity in a furniture industry. International Journal of Advanced Engineering Research and Science, v. 6, n. 5, p. 587-610, 2019.

MENDES, T. R. G. S. M. Marketing educacional como instrumento de gestão e administração nos estabelecimentos escolares. 2013. 159 f. Dissertação (Mestrado em Ciências da Educação e da Formação) - Universidade do Algarve, Portugal, 2013. 
MINAS GERAIS. Comitê extraordinário Covid-19. Minas Gerais, 2020. Disponível em:https://anec.org.br/wp-content/uploads/2020/03/caderno1_2020-03-21.pdf.

Acesso em: 13 out. 2020.

MORAES, M. A. G.; BORGES, E. C. B.; SÁ, J. A. S. Aplicação da metodologia MASP para redução das perdas na produção de cabos de ferramentas agrícolas: um estudo de caso. São Carlos: In: ENCONTRO NACIONAL DE ENGENHARIA DE PRODUÇÃO, 30., Anais [...], São Carlos, 2010.

MORAIS, M. G.; SILVA, A. R.; VERAS, G. P.; FERREIRA, M. T. M.; A gestão da qualidade na prestação de serviços: um estudo de caso em um restaurante localizado em São Luís - MA. Encontro Nacional de Engenharia de Produção, XXXVII, Joinville, 2017.

MOREIRA, L. M.; LOOS, M. J. Análise de rupturas de abastecimento de produtos em uma padaria por meio do Diagrama de Ishikawa. Revista Espacios, v. 39, n. 3, 2018.

MURICI, I.; CHAVES, N. Gestão para resultados na educação. 2. ed. Nova Lima: Falconi Editora, 2016.

NICOLAO, F. Proposição e implantação de melhorias de processo com base no método MASP: estudo de caso em uma indústria de papel e celulose do estado do Paraná. O Papel, v. 79, n. 3, p. 79-84, mar. 2018.

NOVASKI V.; FREITAS, J. L.; BILLIG, O. A. Aplicação de matriz GUT e gráfico de Pareto para priorização de perdas no processo produtivo de uma panificadora. International Journal of Development Research, v. 10, n. 11, p. 42203-42207, 2020.

OLIVEIRA, F. M. V. B.; ALBERTIN, M. R; PONTES, H. L. J. Aplicação de ferramentas da qualidade para melhoria do controle de estoque no atacado e varejo alimentício. Revista Sodebras, v.13, n.155, p. 75-80, 2018.

OLIVEIRA, A. L.; HU, O. R. T. Gerenciamento do ciclo da qualidade. Rio de Janeiro: Alta Books, 2018.

OLIVEIRA, A. O.; DUARTE A. W. B.; CLEMENTINO A. M.A nova gestão pública no contexto escolar e os dilemas dos(as) diretores(as). Revista Brasileira de Política e Administração da Educação. v. 33, n. 3, p. 707-726, set./dez. 2017.

PACANA, A.; SIWIEC, D. The use of quality management techniques to identify sources of incompatibilities in Sealants. Scientific Papers of Silesian University of Technology - Organization and Management Series, n. 143, 2020.

PASSERO, G.; ENGSTER, N. E. W.; DAZZI, R. L. S. Uma revisão sobre o uso das TICs na educação da geração Z. Centro Interdisciplinar de Novas Tecnologias na Educação (CINTED). v. 14, n. 2, 2016. 
PEREIRA, M. P.; ROYER, R. Mapeamento do fluxo de valor aplicado em uma empresa de fertilizantes da região sul. Brazilian Journals of Business, v.2, n. 3, p.2506-2518, Curitiba, 2020.

PERUSSI, P. R.; ALVES, R. R.; LIMA, M. G. Redução de tempos e custos no cadastro de documentação técnica: o caso da melhoria do desempenho dos processos do GATE 0 fornecedor. Revista Tuiuti: Ciência e Cultura, v.6, n.61, p. 148-186, Curitiba, 2020.

RIO DE JANEIRO. Decreto n 46.970/2020. Dispõe sobre as medidas de enfrentamento da propagação do Novo Coronavírus (Covid-19), em decorrência da situação de emergência em saúde, e dá outras providências. Disponível em: http://www.ioerj.com.br/portal/modules/conteudoonline/mostra_edicao.php?session=VGtSbk5VOVVaelZOZWxWMFVtdFJORTVwTURC TIJGcEVURIZKTWsxRWEzUINSVVV5VFdwVmQwMXFRWHBOUkdNeVRWUIZORT VFUlhwTmVsVXdUa0U5UFE9PQ. Acesso em: 28 fev. 2021.

SHARMA, V.; GROVER, S.; SHARMA, S. K. Applicability of quality tools and techniques in manufacturing and service organizations: a comprehensive survey. Internation Journal Six Sigma and Competitive Advantage, v. 12, n. 1, 2020.

SILVA, A. E. A. O uso do Google Classroom como recurso pedagógico em tempos de Covid-19: uma prática de ensino na escola Maria Vieira de Pinho, em Ipaporanga-CE. Revista Nova Paideia, v. 2, n. 2. p.25-38, 2020.

SILVA, A. M; GODIM, J. J. C.; ALBUQUERQUE, R. O.; VILLALBA, L. J. G. A Methodology to Evaluate Standards and Platformswithin Cyber Threat Intelligence. Future Internet, 2020, v. 12, n. 108, p. 1-23, 2020.

SILVA, C. R.; SILVA, R. D. P. Em tempos de coronavírus, como manter a formação em cadeia criativa e a humanidade na escola por meio das tecnologias digitais de informação e comunicação. In: CONGRESSO INTERNACIONAL DE EDUCAÇÃO E TECNOLOGIA. Anais [...], UFSCar 2020. Disponível em: https://cietenped.ufscar.br/submissao/index.php/2020/article/view/1613/1254 Acesso: 26 fev. 2021.

SILVA, J. M.et al. Implementation of quality tools in a stuffed pasta industry. Research, Society and Development, v. 9, n.8, 2020.

SOUZA, S. N. Evasão escolar na educação técnica em regime de internato: um estudo de caso múltiplo. 2020. 109 f. Dissertação (Mestrado em Administração) Universidade Federal Fluminense, Rio de Janeiro, 2020.

TEIXEIRA, B. D. O. R. As tecnologias de informação e comunicação e sua utilização na Educação Infantil: um estudo de caso da prática pedagógica em uma escola particular de Santa Maria. 2019. 25f. Trabalho de Conclusão de Curso (Especialista em Mídias da Educação) - Especialização em Mídias na Educação (EaD) da Universidade Federal de Santa Maria, Santa Maria, Rio Grande do Sul, 2019. 
TEIXEIRA, J. M.et al. Proposta de fluxograma para design de interfaces digitais: um exemplo prático de como transformar informações de projeto em requisitos de função e conteúdo. Brazilian Journal of Development, v. 6, n.5, p.31531-31548, 2020.

TRINDADE, V. T.et al. Process optimization of an emergency unit, using the quality tools, MASP and PDCA. International Journal for Innovation Education and Research, v.7, n.10, p. 174-187, dez. 2019.

VENANZI, D.et al. Application of quality tools in solving problems in the production process of an ABC company: case study. Revista Científica Hermes, v. 22, p. 583605, 2018.

VIANA, P. V. G.; SAMED, M. M. A. Aplicação da metodologia de análise e solução de problemas (MASP) no processo de expedição de uma agroindústria. 2017. 31f. Trabalho de Conclusão de Curso (Engenharia de Produção) - Universidade Estadual de Maringá, Paraná, 2017.

WERKEMA, M. C. C. Ferramentas estatísticas básicas para o gerenciamento de processos. Belo Horizonte: Fundação Christiano Ottoni, 1995. 
Agência Brasileira ISBN ISBN: 978-65-86230-90-1 